\title{
Justificaciones públicas: el lenguaje en la vida moral y política
}

Marieta Quintero Mejía 


\section{Justificaciones públicas: el lenguaje en la vida moral y política}

Marieta Quintero Mejía

Docente

Universidad Distrital Francisco José de Caldas 


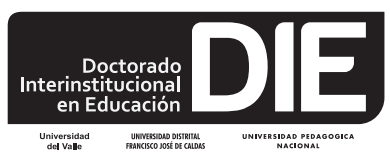

Comité Editorial Interinstitucional-CAIDE

Carlos Javier Mosquera Suárez

Director nacional

Alexander Ruíz Silva

Coordinador DIE,

Universidad Pedagógica Nacional

Sandra Soler Castillo

Directora DIE,

Universidad Distrital Francisco José de Caldas

Jaime Humberto Leiva

Coordinador DIE,

Universidad del Valle

\section{Comité Editorial CADE}

Sandra Soler Castillo

Presidenta CADE

William Manuel Mora Penagos

Representante grupos de investigación:

Interculturalidad, Ciencia y Tecnología-INTERCITEC, y del Grupo Didáctica de la Química-DIDAQUIM, del

Énfasis de Educación en Ciencias.

Dora Inés Calderón

Representante de los grupos de investigación:

Moralia, Estudios del Discurso, Filosofía y Enseñanza de la Filosofía, Grupo de investigación

Interdisciplinaria en Pedagogía de Lenguaje y las Matemáticas-GIIPLyM y Jóvenes, Culturas y

Poderes, del Énfasis de Lenguaje y Educación.

Martín Eduardo Acosta Gempeler

Representante de los grupos de investigación: Grupo de Investigación Interdisciplinaria en Pedagogía de Lenguaje y las Matemáticas

GIIPLyM, Matemáticas Escolares Universidad Distrital-mESCUD y Edumat, del Énfasis de Educación Matemática.

Bárbara García Sánchez

Representante de los grupos de investigación: Formación de Educadores, del énfasis de Historia de la Educación, Pedagogía y Educación Comparada.
UNIVERSIDAD DISTRITAL

FRANCISCO JOSÉ DE CALDAS

\section{Roberto Vergara Portela}

Rector (E)

Universidad Distrital Francisco José de

Caldas

Borys Bustamante Bohórquez

Vicerrector Académico

Universidad Distrital Francisco José de

Caldas

ISBN impreso: 978-958-8832-89-0

ISBN digital: 978-958-8832-90-6

Primera edición

(C) U. Distrital Francisco José de Caldas

Preparación Editorial

Doctorado Interinstitucional en Educación Sede U. Distrital Francisco José de Caldas http://die.udistrital.edu.co

\section{Elban Gerardo Roa Díaz}

Asistente Editorial

eventosdie@udistrital.edu.co

\section{Fondo de publicaciones}

U. Distrital Francisco José de Caldas

Cra. 19 No. 33-39. Piso 2.

PBX: (57+1) 3238400, ext. 6203

publicaciones@udistrital.edu.co

Corrección de estilo

Luisa Juliana Avella Vargas

Impreso en Javegraf

Bogotá, Colombia, 2014

Prohibida la reproducción total o parcial de la presente obra por cualquier medio sin permiso escrito de la Universidad Distrital Francisco José de Caldas. 


\section{Justificaciones públicas: el lenguaje en la vida moral y política}

Marieta Quintero Mejía

Docente

Universidad Distrital Francisco José de Caldas 


\section{CONTENIDO}

\section{CAPÍTULO I}

\section{¿QUÉ ENTENDEMOS POR JUSTIFICACIONES Y LENGUAJE EN LA VIDA MORAL?}

1.1. La pragmática del lenguaje y su aporte en el estudio de las justificaciones en ética y política

1.2. Justificaciones morales y políticas en la orientación deliberativa

1.3. Justificación pública acerca de la justicia: pragmática universal del lenguaje y la razón pública

1.3.1 Lo racional y lo razonable en la justificación en asuntos de justicia

1.3.2. Aspectos formales presentes en la justificación pública de la justicia 


\section{CAPÍTULO II}

EL SENTIDO DE JUSTICIA Y LA GRAMÁTICA DE LOS SENTIMIENTOS

\section{CAPÍTULO III}

\section{INVESTIGACIONES ACERCA DE LA VIDA CON LOS OTROS 43}

3.1. Itinerarios de los discursos en la reconstrucción de la lógica moral en el joven universitario

3.2. Justificaciones de jóvenes universitarios y jóvenes desplazados acerca de la concepción de justicia

3.2.1. Categorías y sub-categorías de análisis

3.2.2. Los límites del carácter deliberativo de las justificaciones morales en jóvenes universitarios y jóvenes desplazados en situaciones de conflicto interno: ética ante las víctimas

3.3. Los sentimientos morales y políticos en el ejercicio ciudadano: ¿un asunto de formación?

3.3.1. Acerca de los sentimientos en la ciudadanía

3.3.2. Atributos de los sentimientos morales y políticos

3.3.3. Estigmas acerca de los sentimientos morales en la formación ciudadana

3.3.4. Estigmas en la formación ciudadana: textos escolares

3.3.5. Acerca de la formación ciudadana y los sentimientos en Colombia 
"Si la justicia perece, no le merece a los hombres vivir sobre la tierra»

Kant 1989, p. 167 


\section{PRESENTACIÓN ${ }^{1}$}

Desde la antigüedad griega se considera que el lenguaje, por su estructura intersubjetiva, configura el Ethos o conjunto de rasgos y comportamientos de un sujeto o una comunidad. Por ello, en buena medida, los filósofos de la moral y la política, desde distintos marcos y métodos de análisis, se han orientado al estudio del significado del lenguaje para indagar asuntos relacionados con las acciones morales y políticas, así como para analizar los compromisos, acuerdos, promesas y juicios de valor que emiten los ciudadanos en sus vínculos comunitarios y en sus relaciones con las instituciones políticas.

En este libro se analizan, precisamente, corrientes y tendencias centradas en el estudio de las justificaciones en asuntos relacionados con la justicia, pero también con la injusticia. Asimismo se presentan investigaciones en las cuales el tema central es indagar acerca de la vida con los otros, en especial, en el marco del conflicto armado.

En el tema de las justificaciones encontramos que la teoría deliberativa de Rawls y Habermas, a pesar de pertenecer a tradiciones filosóficas distintas²,

1 Los desarrollos conceptuales y empíricos expuestos en este capítulo acerca de las justificaciones morales y políticas hicieron parte de las discusiones establecidas con Eloísa Vasco y con el maestro Guillermo Hoyos, a quienes les debo sus orientaciones y precisiones.

2 Habermas y Rawls provienen de tradiciones filosóficas distintas. Mientras Habermas califica su obra de «kantismo republicano», Rawls suscribe su teoría al «liberalismo político». La diferencia entre la teoría liberal y el republicanismo consiste en que, mientras para la primera la injerencia del poder político debe restringirse al mínimo posible, para el republicanismo las acciones deben estar reguladas mediante procesos de auto-reglamentación (darse las leyes a sí mismo) con el propósito de ampliar la esfera de la autodeterminación colectiva y restringir todo tipo de regulación que promueva acciones heterónomas (Bobbio, 1985, p. 199). A pesar de las diferencias en la tradición filosófica, los dos autores - Habermas y Rawls- buscan presentar una concepción pública de la justicia válida para sociedades contemporáneas y proponen procedimientos para alcanzar el consenso, en el caso de Habermas por medio del diálogo; en el caso de Rawls, por medio del contrato. 
consideran que los sujetos en situaciones de deliberación pública emplean sus razonamientos o inferencias con el objeto de establecer acuerdos y alcanzar el entendimiento. En esta teoría, los ciudadanos se entienden como defensores de sus propias doctrinas, capaces de discutir, decidir y buscar mecanismos de entendimiento sobre asuntos constitucionales, en especial sobre aspectos relacionados con la justicia. En el modelo deliberativo, el ciudadano es la persona encargada de justificar lo que considera como acertado o equivocado, bueno o malo, justo o injusto, en relación con los asuntos de la justicia y de praxis ciudadana.

Esta orientación deliberativa sostiene que los ciudadanos esperan que los valores de la justicia, que han justificado públicamente, estén presentes tanto en las instituciones políticas como en las políticas sociales. En consecuencia, en toda justificación pública, los ciudadanos muestran el derecho que tienen para realizar exigencias a sus instituciones, promover formas de asociación políticas y no políticas, poseer una concepción del bien, perfilar una forma de vida y participar de la cooperación social. La orientación deliberativa permite mostrar que, en sociedades democráticas, las justificaciones públicas están afectadas por las diversas doctrinas religiosas, filosóficas y morales presentes en la sociedad civil.

Al respecto, los ciudadanos conocen los principios de la vida moral y política presentes en las diversas doctrinas comprehensivas a través de la cultura política pública, es decir, a partir de su formación y de sus vivencias, adquiridas en el proceso de educación como ciudadanos. Esta cultura política define, en gran medida, las justificaciones públicas acerca de la justicia, y promueve en los ciudadanos actitudes de optimismo y confianza en su futuro (Rawls, 1996).

En tal sentido, la orientación deliberativa ofrece en este estudio postulados teóricos para el análisis de las deliberaciones públicas acerca del ejercicio ciudadano. Postulados teóricos que provienen de la psicología moral de Piaget, aunque en especial, de Kohlberg. Las tesis del modelo evolutivo de la moral, de Piaget y Kohlberg pueden dar firmes respuestas a los aspectos relacionadas con los rasgos del razonamiento moral que encontramos en las justificaciones de la justicia (De Lora, 2004).

Sin embargo, en este libro, el análisis de las justificaciones no se restringe al marco de interpretación teórica. Interesa conocer los modos de justificación de niños, niñas y jóvenes en asuntos relacionados con la justicia, pero también en su ejercicio ciudadano, en particular, en contextos afectados 
por el conflicto armado. Por ello, se acompaña el capítulo de fundamentación con los resultados de cuatro proyectos de investigación. Dos de estas investigaciones orientadas al estudio de las justificaciones en asuntos de justicia, las otras dos, relacionadas con experiencias ciudadanas en contextos afectados por la dominación y subordinación, así como por la vulneración de derechos propia del conflicto armado colombiano.

A partir de las justificaciones públicas que manifiestan algunos niños, niñas y colombianos, se buscó, justamente, mostrar la importancia que tiene que los ciudadanos conciban la justicia y la praxis ciudadana como esenciales para promover el desarrollo humano, garantizar los derechos fundamentales y fomentar la búsqueda de los principios de equidad y de reconocimiento. Propender por una concepción de la justicia como sistema social exige superar la precaria conciencia y cultura jurídica que tienen los niños, niñas y jóvenes colombianos (Garay, 2002; Gómez Buendía, 2003); Favorecer la formación de una cultura política significa encaminar los esfuerzos hacia la construcción de un proyecto democrático basado en la cooperación social exigible para la constitución de una sociedad justa y equitativa (Garay, 2002).

Un aporte de estos estudios fue dotar de nuevos significados algunos de los hallazgos encontrados en las investigaciones que se han realizado en nuestro país respecto de la concepción pública de la justicia y de la praxis ciudadana. En efecto, se espera poder ampliar el marco de explicación propuesto en los estudios de Garay (2002) y Gómez Buendía (2003) acerca de por qué en nuestro país las políticas de la justicia y ciudadanía no han sido objeto de un debate democrático y las razones por las cuales estas políticas han sido establecidas, principalmente, para enfrentar desafíos coyunturales. Paralelamente, se espera interpretar por qué la anterior situación ha llevado a que los colombianos perciban el aparato judicial como algo excepcional, estratégico y como un asunto institucional, circunscrito a experiencias personales no generalizables.

Estos estudios permiten comprender por qué los colombianos, en este caso los niños, niñas y jóvenes, conciben el aparato judicial como estratégico. Para Garay (2002), los jóvenes ven la justicia como algo estratégico porque esta es a menudo adaptada en nuestro país a cada nueva situación, es decir, según la lógica individual de costos y beneficios (Garay, 2002).

En gran medida, los colombianos perciben el aparato jurídico y el ejercicio ciudadano como algo puramente excepcional y estratégico porque 
las decisiones judiciales y políticas son acogidas cuando estas son útiles, pero se cuestionan y se deslegitiman cuando afectan los propios intereses. Esta situación se debe, en gran medida, a que los ciudadanos no saben con exactitud qué normas los gobiernan y cuáles son los valores que dichas normas promueven (Garay, 2002).

Podría decirse que el nivel de conflicto armado y de violencia en la sociedad colombiana en general, y sus efectos en la población, el grado de desconfianza y la poca participación en escrutinios y deliberaciones públicas, el desconocimiento de las normas, las leyes y las instituciones que la administran, los estrechos marcos de interpretación de las normas y de las reglas restringidos al ámbito privado son, entre otros, algunas razones que mostrarán la importancia que tiene adelantar estudios acerca de las justificaciones públicas en asuntos de la justicia y del ejercicio ciudadano, desde los presupuestos de la filosofía ética y política.

Las investigaciones sobre actitudes, emociones, acciones y conocimientos relacionados con el tema de la deliberación pública se han realizado desde distintos campos del conocimiento con sus correspondientes métodos de indagación. En estas investigaciones encontramos algunas reflexiones de orden formal, y otras de carácter empírico. Dentro de las primeras presento, en el primer capítulo, los prepuestos filosóficos de Habermas y Rawls, así como los de la piscología moral de Piaget y Kohlberg.

Si bien entre los autores en mención es común encontrar una preocupación por la justicia y la ciudadanía, algunas de las diferencias radican en que para Habermas y Rawls la vida ciudadana se relaciona con los mecanismos de justificación y de deliberación de los ciudadanos en la esfera pública. Por su parte, para Piaget y Kohlberg este tema se refiere a los modos de razonamiento de los ciudadanos. Habría que aclarar que los modos de razonamiento, si bien tienen un peso en la esfera cognitiva, también se refieren a las acciones realizadas por los ciudadanos en la esfera social.

Tanto los puntos de encuentro como los de desacuerdo entre los autores en mención han sido el motor para la realización del segundo tipo de contribuciones: investigaciones teóricas y empíricas. Algunos interrogantes de los investigadores se han orientado a otorgar validez a los hallazgos deliberativos acerca de la justicia y la vida ciudadana (Hoyos, 1998a). Otros se han centrado en identificar sus limitaciones (Walzer, 1993). También encontramos el interés por la comprensión de los modos de significación que tienen los ciudadanos de la justicia y del vivir juntos (Gusti, 2001). Asimismo, cabe 
resaltar aquellas investigaciones relacionadas con los modos de acción y razonamiento moral sobre la justicia (Restrepo, B.; Quintero, M., 2000).

Algunos resultados de estos estudios se presentarán a lo largo del desarrollo del acápite teórico, no obstante, se dedicará un capítulo para presentar en extenso cuatro (4) investigaciones empíricas. Dos (2) de estos estudios fueron realizados con el apoyo de COLCIENCIAS, acerca de las justificaciones públicas de la justicia; otro (1), referido al impacto que ha tenido el conflicto armado en la escuela, investigación que contó con el apoyo de COLCIENCIAS E ICFES. La cuarta investigación estuvo centrada en el estudio de los sentimientos morales y políticos y su lugar en la formación ciudadana. Algunas de las poblaciones se encontraban en condición de desplazamiento como consecuencia del conflicto interno colombiano, otras viven en contextos afectados por el conflicto armado colombiano. Otro grupo de jóvenes se encontraba en proceso de formación universitaria en instituciones de educación Superior de carácter privado y público.

A pesar de las diferencias entre los mismos teóricos y en las producciones investigativas empíricas, es común encontrar el interés por el estudio del lenguaje o justificaciones acerca de la vida ética y política. En otras palabras, el ejercicio ciudadano se ha estudiado a partir del lenguaje en sus dimensiones ética y política. Para ello se ha procedido a analizar las deliberaciones públicas de los ciudadanos, lo que explica el título del presente libro.

La importancia de los dos tipos de investigación de naturaleza tanto teórica como empírica, radica en ofrecer marcos y enfoques conceptuales y metodológicos para la realización de estudios, iniciativas pedagógicas y de acción colectiva en asuntos referidos al ejercicio ciudadano. Inicialmente, se presenta lo que se entiende por justificación en ética y política (el lugar del lenguaje en la vida moral y política). Posteriormente, se desarrollan los presupuestos teóricos acerca de la justicia en su carácter deliberativo y cognitivo. Finalmente se dan a conocer los cuatro estudios empíricos. 


\section{CAPÍTULO I}

\section{¿QUÉ ENTENDEMOS POR JUSTIFICACIONES Y LENGUAJE EN LA VIDA MORAL?}

Desde la filosofía clásica, la justificación de las acciones morales ocupó un lugar central; no obstante, es la filosofía moral contemporánea la que se ocupa de los temas de la moral y la política a partir del estudio del lenguaje (Tungendhat, 2002).

El interés de la filosofía moral contemporánea por el significado de los conceptos de la ética -bueno y malo; correcto e incorrecto; adecuado e inadecuado- y por los problemas relacionados con la validez de las justificaciones morales, dio lugar a la consolidación del Ilamado giro lingüístico en filosofía, cuyo principal representante es Austin (Pieper, 1991). Al giro lingüístico, en su corriente de la pragmática del lenguaje, se le dedicará el capítulo siguiente, de manera que se pueda mostrar el papel del lenguaje en los estudios de la ética y la política.

En cuanto a las reflexiones acerca del lenguaje moral, filósofos como Hudson (1987), Hare (1999), Tungendhat (2000) y Habermas (1987) reconocen que toda justificación moral que hace parte de la praxis moral o de la vida cotidiana, posee una intención comunicativa, aspecto desarrollado en la pragmática del lenguaje. La tarea del filósofo moral consiste, precisamente, en el análisis de las justificaciones que emite el moralista (profano) en la esfera de la vida social.

En otras palabras, para Hudson (1987) el moralista toma parte en la justificación moral presentando las razones acerca de lo que es correcto e incorrecto, justo e injusto, mientras que el filósofo moral plantea interrogantes 
relacionados con la manera como el moralista utiliza el lenguaje para justificar hechos o para proferir mandatos, promesas y juramentos. Adicionalmente, en estos debates se pondera la justificación moral y política porque en ella reside, en buena medida, la solución pacífica de los conflictos entre ciudadanos pertenecientes a sociedades plurales.

Si bien en estas reflexiones filosóficas encontramos que la moralidad se manifiesta en un lenguaje moral, tenemos que no existe consenso entre los filósofos acerca de lo que es una justificación moral, ni sobre la validez de las expresiones consideradas «moralmente buenas» $\mathrm{o}$ «moralmente malas» (Pieper, 1991). Las dos corrientes filosóficas que han generado los debates más importantes en el llamado giro lingüístico en filosofía son la analítica y la ética discursiva o dialógica.

La corriente analítica, que surge en 1903 en Gran Bretaña con la obra de Moore, se orientó al conocimiento, exclusivamente, de la forma lingüística de los enunciados morales. La propuesta de Moore, centrada en el análisis de la estructura de los enunciados lingüísticos, motivó nuevas investigaciones con distintos métodos de análisis. Estos estudios dieron lugar, dentro de la misma corriente, a la constitución de diferentes tipos de orientaciones acerca del significado de la justificación moral; estas son el intuicionismo, el emotivismo y el positivismo.

En cuanto a la corriente filosófica de la ética discursiva o dialógica, el interés se centró, contrario a la corriente analítica del mundo Anglosajón, en el carácter hermenéutico del lenguaje moral. En efecto Habermas (1994) y Apel (1999), como representantes de la ética discursiva, adoptan la hermenéutica como propuesta filosófica en la que se propone, siguiendo a Kant, que los individuos pueden entender a alguien mejor de lo que él mismo se entendió a sí mismo porque saben más o porque son más conscientes que él de algunas cosas. Por lo tanto, la hermenéutica significa que cada vez es posible comprender e interpretar mejor (Apel, 1999).

Si bien estos dos filósofos representantes de la ética discursiva asumen la hermenéutica desde la capacidad de comprensión del individuo por la vía de la argumentación, difieren en el método adoptado para entender su significado y su alcance. Así pues, Apel (1999) adopta la hermenéutica trascendental y Habermas (1994) una hermenéutica situada, orientada a la reconstrucción de las normas de acción social vigentes. La acogida de métodos distintos para entender el carácter hermenéutico de la justificación moral, también dio lugar, tal como sucedió con la corriente filosófica 
analítica, a la constitución de dos orientaciones de la ética discursiva o dialógica: la trascendental y la reconstructiva. Adopto la segunda, es decir la reconstructiva, porque permite comprender e interpretar, en contextos de acción, las deliberaciones de los ciudadanos en asuntos de la justicia.

En consecuencia, se utiliza el término de orientaciones de las justificaciones morales y políticas para diferenciar entre los distintos métodos de análisis empleados en el estudio de las justificaciones en las dos corrientes filosóficas enunciadas (analítica y discursiva o dialógica); métodos que han sido utilizados para explicar lo que se entiende por justificación moral, para describir y comprender la argumentación de los profanos acerca de lo que es moralmente acertado o equivocado y para entender la postura que adoptan los filósofos morales, adscritos en las orientaciones enunciadas, cuando analizan lo que dicen los moralistas acerca de lo que hacen en su vida cotidiana.

\subsection{La pragmática del lenguaje y su aporte en el estudio de las justificaciones en ética y política}

Los alcances, entre otros, de la denominada pragmática del lenguaje propuesta por Austin alrededor de 1955, consistieron en plantear la distinción entre enunciados de la ciencia de aquellos enunciados cuyo significado depende del uso en su contexto de emisión. La diferencia entre los significados que generamos al hablar es que algunos son intencionales y otros no. La pragmática analiza, precisamente, cómo producimos significado intencional; es decir, cómo decimos lo que queremos decir y en cómo lo comprendemos cuando nos lo dicen.

Por ello, podríamos manifestar que la pragmática es una disciplina que estudia aquellos factores que determinan el uso del lenguaje (Escandell, 1996). Adicionalmente, se ocupa del lenguaje en su función comunicativa, atendiendo al contexto y a todos aquellos aspectos que están por fuera de lo convencional de las expresiones lingüísticas (Nubiola \& Conesa, 1999). Estudia cómo los hablantes interpretamos enunciados dentro de un contexto. Se analizan los principios que guían la interpretación de las enunciaciones: relación con los participantes, con el co-texto lingüístico inmediato, con el contexto y con la situación de comunicación, incluidas las creencias de los hablantes, la imagen de sí mismos y los conocimientos del lenguaje que usan y del mundo. 
Otro aporte de esta corriente renovadora de la pragmática consistió en indicar que existen algunas expresiones comunicativas, que cuando las proferimos, hacemos cosas (hablar es hacer). Austin llama a este tipo de expresiones proferencias realizativas, y en ellas es importante no la expresión como tal, sino su emisión o pronunciación para realizar el acto de que se trate (bautizar, aconsejar, prometer...). Así, cuando decimos «prometo que...», no se está haciendo una descripción, sino la realización del acto de prometer.

Austin (1990) sostiene que los filósofos, durante mucho tiempo, han propuesto que el papel de un enunciado solo puede ser describir un estado de cosas o enunciar algún hecho (enunciado constatativo). Por ello, sugiere iniciar investigaciones relacionadas con el uso del llamado por él mismo «lenguaje ordinario», expresión con la que se quiere sostener que parte de los problemas de la filosofía se originan por las confusiones o abusos que se hacen del lenguaje y porque el filósofo pretende analizar los problemas por fuera de los contextos donde cumplen cabalmente su función.

Si la tarea de la filosofía, señala Austin, consiste básicamente en la elucidación de conceptos ordinarios, el estudio de la filosofía no debe ser el de los enunciados descriptivos, fácticos o constatativos, sino el de los enunciados que tienen la característica de ser realizativos, porque al emitirlos realizamos una acción.

En la teoría realizativa del lenguaje, Austin analiza los enunciados que tienen juicios éticos. Entre estos tenemos, a manera de ilustración, que la proferencia de un juramento implica el acto de jurar, así como las emisiones morales de prometer, aconsejar y jurar, entre otras, implican la realización simultánea del acto que en ella se profiere. El carácter realizativo de lenguaje moral posee los siguientes rasgos:

a. Las expresiones del lenguaje moral tienen que ver con las posibilidades de acción y con las formas de comportamiento de las personas.

b. Los enunciados morales son convencionales. Sin embargo, no es suficiente con identificar las normas o reglas que están sobre la base de los enunciados para determinar el carácter moral de los individuos. En tal sentido, la moral del individuo se manifiesta en la bondad por la norma y en el reconocimiento práctico de las mismas (Craemer-Ruegenberg, 1976).

c. Las expresiones morales expresan, además de las intenciones de los individuos, las formas y mecanismos de interacción (intersubjetividad). 
Lo común a estos rasgos consiste en considerar que los predicados morales adquieren su significado en el uso o en vida cotidiana. Los desarrollos de esta hipótesis nos sitúan, en principio, en las teorías del lenguaje y la comunicación de Austin y Habermas. Teorías complementarias en su marco de definición acerca del papel realizativo del lenguaje y disímiles en cuanto a los alcances a los que aspiran. Los actos de habla como unidad de análisis definen, en el caso del filósofo del lenguaje Austin, el carácter performativo del lenguaje, mientras que Habermas los interpreta en el marco de la acción y el conocimiento a la luz de las pretensiones de validez que están encaminadas a propiciar el entendimiento en la comunicación.

Mientras Austin, para su fundamentación de la teoría de los actos, reconoce el marco de las convenciones y la regulación de los acuerdos establecidos por quienes hacen uso del lenguaje ordinario, Habermas, en su ética discursiva, además de retomar los presupuestos de Austin, adopta los criterios de validez para alcanzar el entendimiento.

La investigadora Craemer-Ruegenberg (1976) afirma que es precisamente la teoría de Austin la que permite entender que las justificaciones morales se expresan en un lenguaje moral que no es descriptivo como el de la ciencia, sino prescriptivo, el cual está relacionado con las acciones humanas. Este lenguaje moral es convencional y está conformado por actos de habla que expresan una obligación o un «deber ser». Por lo tanto, existe una relación entre prescripción y acción, a pesar de que la primera sea universal y la segunda, individual. Para Austin, toda justificación moral motiva la realización de acciones morales convencionalmente aceptadas.

En consecuencia, el filósofo Austin (1990) propicia el giro en los estudios acerca de la justificación moral. Este giro consiste en sustituir el carácter descriptivo del estudio de la misma por el carácter performativo, ampliar el análisis centrado en el "look and see», por conocer "qué hacemos con las palabras» y ampliar los marcos de estudio orientados a conocer las deducciones lógicas de su uso, por el estudio acerca de cómo se usa el lenguaje (Camps, 1976).

Los esfuerzos de la filosofía del lenguaje -en particular de Austin- en asuntos de moral, ofrecieron marcos de interpretación acerca de la naturaleza de las justificaciones en las que los individuos expresan los motivos o razones de su adhesión o no a principios y normas morales. Las justificaciones son empleadas para conceder validez a las acciones morales. En otras palabras, los sujetos morales siempre están obligados a presentar las 
«buenas razones» que justifican una toma de decisión moral, la aceptación o rechazo de una norma moral y la realización de una acción moral (Camps, 1976).

\subsection{Justificaciones morales y políticas en la orientación deliberativa}

Habermas (2002) retoma la propuesta de Austin del carácter realizativo del lenguaje y señala que los predicados morales adquieren significado en el uso o en la vida cotidiana. Para Habermas (2002), el lenguaje moral está constituido por tres tipos de manifestaciones: por juicios relativos a cómo debemos comportarnos, por reacciones de aprobación o rechazo y, en especial, por reacciones mediante las cuales las partes en disputa pueden justificar su actitud de aprobación o rechazo.

Habermas retoma el carácter realizativo del lenguaje de Austin, así como su propuesta de los actos de habla, como unidad de análisis de las expresiones morales. No obstante, mientras para Austin en los actos de habla ilocucionarios encontramos las expresiones morales por el carácter de obligación que en estos se expresa (ordenar, prohibir, prometer, entre otros), Habermas, además de identificar el lenguaje moral con los actos de habla ilocucionarios, propone las pretensiones universales de validez orientadas a propiciar el entendimiento.

La propuesta de Habermas de los fenómenos morales, atendiendo a los criterios de validez que están en la base de los actos de habla, explica por qué podemos considerar su proposición de justificación moral dentro de la orientación deliberativa. Para la investigadora Pieper (1991) en esta orientación, tal como se viene enunciando, el lenguaje se entiende como acción comunicativa sobre asuntos prácticos relacionados con las normas morales.

Para Habermas (1984), las cuatro pretensiones de validez que los hablantes competentes han de entablar mutuamente en cada uno de sus actos de habla son: (i) inteligibilidad para las emisiones o manifestaciones, de suerte que todo el que domine los sistemas de reglas lingüísticas pueda generar estas mismas emisiones o manifestaciones; cuando una manifestación se torna problemática, el hablante hace preguntas del tipo ¿qué quiere decir con eso?, ¿cómo hemos de entender eso?, entre otras. (ii) La pretensión de verdad del contenido proposicional de una emisión está relacionada con los actos de habla constatativos y se expresa en verbos como describir, 
afirmar, referir, narrar, exponer y explicar; cuando se torna problemática esta pretensión de validez, los hablantes hacen preguntas tales como: ¿son las cosas como tú dices? y ipor qué eso es así y no de otra manera? (iii) La pretensión de validez de rectitud indica que las normas de acción (o de valoración) vigentes son reconocidas; en caso de tornarse problemática esta pretensión, los hablantes entablan preguntas del tipo: ¿por qué has hecho eso?, ¿por qué te has comportado así? y ¿te es lícito hacer eso? (iv) Finalmente, la pretensión de validez de veracidad que no corresponde al plano discursivo, indica Habermas, expresa las intenciones y las actitudes de los hablantes (Habermas, 1984).

Las pretensiones de validez permiten a los miembros de la sociedad compartir un discurso, adoptar una postura crítica, orientar sus interacciones comunicativas hacia el libre intercambio de argumentos y generar condiciones que favorezcan los acuerdos intersubjetivos entre los actores sociales. Las pretensiones de validez están presentes tanto en las interacciones comunicativas como en las acciones, las teorías y las normas sociales.

Por tanto, las pretensiones de validez que se reflejan en los actos de habla, expresan las competencias que tienen los individuos en el mundo de la vida (Habermas, 1987). Las pretensiones de validez están presentes en los distintos enunciados que profieren los individuos cuando asumen los roles en la sociedad. En consecuencia, todo acto de habla tiene un "asiento» en la praxis comunicativa cotidiana (Sobrevilla, 1987).

En esta orientación deliberativa tenemos que la justificación de una norma moral tiene dos niveles. En el primero encontramos que el individuo problematiza, expone y contra-expone sus puntos de vista morales a quienes participan en la deliberación. En este nivel, el propósito es clarificar las posiciones de las partes y presentar las razones que cada cual tiene a favor del juicio que ha sido considerado como merecedor del debate. En el segundo nivel, el sujeto se orienta hacia la búsqueda del consenso a partir del uso de argumentos racionales y ajustados a los criterios de «buena voluntad». En este nivel, el interés es la emisión de argumentos que tengan «fuerza moral» para motivar racionalmente a quienes participan en el proceso de justificación, de manera que consideren dichos argumentos lo suficientemente fundamentados (Habermas, 2002).

En conclusión, tenemos que los filósofos Austin (1990) y Habermas (1984) reconocen el carácter realizativo del lenguaje, la naturaleza convencional de estos tipos de lenguaje y el carácter intersubjetivo que subyace a este 
tipo de lenguaje. Adicionalmente, para estos filósofos el lenguaje moral está constituido por aquellas emisiones cuya «fuerza moral» motiva a la acción. En otras palabras, cuando el sujeto dice algo con contenido ético, como jurar, al mismo tiempo realiza el acto, en este caso de jurar. Estas emisiones morales no tienen como propósito tener un estatus científico, sino alcanzar las pretensiones de validez para que los individuos coordinen sus planes de acción y logren el entendimiento (Habermas, 1984; 1987).

\subsection{Justificación pública acerca de la justicia: pragmática universal del lenguaje y la razón pública ${ }^{1}$}

Las discusiones filosóficas entre Rawls y Habermas han generado en el ámbito de la filosofía ética y política diversas investigaciones. No obstante, en el presente acápite se retomarán solo los estudios relacionados con la justificación pública de la concepción de la justicia y con el carácter cognitivo de la misma.

En particular, interesa mostrar las investigaciones que se han realizado alrededor de las siguientes afirmaciones:

- Las justificaciones públicas se ajustan a unos procedimientos encaminados a propiciar el entendimiento entre los ciudadanos en sociedades plurales.

- Las justificaciones en asuntos de justicia están relacionadas con las normas y las leyes que han sido reconocidas y aceptadas por los ciudadanos.

- Toda justificación pública contiene las razones que tienen los ciudadanos en asuntos relacionados con la justicia; razones sobre las cuales no siempre hay acuerdos, lo que exige la búsqueda de unos mecanismos de entendimiento o de unos principios de justicia que permitan a los ciudadanos vivir cooperativamente.

- La justificación pública de la justicia en sociedades democráticas se caracteriza por una concepción de la justicia que encarna el pluralismo razonable (Rawls, 2002).

- El concepto de justicia es la vía cognitiva o racional de la moralidad en la medida en que los sujetos siempre tienen que dar razones objetivas o racionales para justificar una toma de decisión (Habermas, 1994).

1 Se recogen algunos aspectos de la investigación doctoral Justificaciones de jóvenes universitarios y jóvenes desplazados acerca de la concepción de justicia, realizada con la orientación de Eloísa Vasco y financiada por colCIENCIAS-CINDE-Universidad de Manizales, 2006. 
Para Rawls, las justificaciones de los ciudadanos se despliegan en la cultura de la sociedad civil; para Habermas, en la esfera pública. La razón pública en Rawls es el razonamiento de los legisladores, ejecutivos, jueces y ciudadanos, quienes justifican asuntos constitucionales y de justicia básica. La razón pública en Habermas está relacionada con la teoría de la acción comunicativa como mecanismo analítico que da cuenta de la verdad y la validez de los juicios morales.

Si bien Habermas y Rawls sostienen que los ciudadanos tienen el hábito de justificar las cuestiones morales y políticas para alcanzar el entendimiento entre ellos, los dos autores difieren en los procedimientos que son requeridos en una justificación y en la manera como los ciudadanos alcanzan el entendimiento en sociedades plurales.

Las divergencias entre Habermas y Rawls acerca de la razón pública sirven como punto de partida para ejemplificar por qué estos autores han realizado uno de los debates contemporáneos más importantes en la filosofía ética y política. Dentro del amplio espectro de posicionamientos que pueden resultar de un debate de esta magnitud, Habermas reconoce que entre la «justicia como equidad» de Rawls y su propuesta de «ética discursiva» solo existen unas limitadas fronteras, o como bien lo llamaría el mismo autor, una «disputa familiar» (Habermas \& Rawls, 1998).

Habermas, desde una perspectiva ética, propone la pragmática universal del lenguaje como mecanismo para entender por qué las justificaciones de los ciudadanos en asuntos relacionados con las normas poseen una fuerza moral.

Esta pragmática universal del lenguaje tiene como tarea identificar y reconstruir las condiciones universales del entendimiento. Las condiciones de una situación ideal del diálogo ${ }^{2}$, que deberían cumplirse en los discursos para que un argumento motive racionalmente a un interlocutor y promueva el entendimiento son, según Barreto (1993):

2 Habermas retoma de Chomsky el concepto de hablante oyente ideal, quien actúa en una comunidad de lenguaje completamente homogénea y que conoce perfectamente su lengua. En la teoría de la pragmática universal del lenguaje propuesta por Habermas, una situación discursiva ideal permite reconstruir los principios que gobiernan la acción comunicativa y las condiciones necesarias para que un argumento motive racionalmente a un interlocutor. Una de las condiciones tiene que ver con la exclusión de toda fuerza coercitiva, excepto la fuerza del mejor argumento. En esta situación discursiva ideal se supone que los acuerdos racionales tienen lugar en situaciones discursivas en las cuales existen convicciones compartidas entre el hablante y el oyente respecto del mundo de la vida (Habermas, 1984). 
1. Igualdad de oportunidades para abrir y continuar discursos.

2. Igualdad de oportunidades para tematizar y criticar opiniones y supuestos.

3. Igualdad de oportunidades para usar actos de habla autorrepresentativos que vuelvan transparente la naturaleza interna del hablante y, por ende, la expresión de sus deseos, intenciones, sentimientos y pareceres.

4. Igualdad de oportunidades para exigir comportamientos en el interlocutor y garantizar una comunicación libre de las compulsiones provenientes de la práctica comunicativa cotidiana.

La pragmática universal del lenguaje se refiere, entonces, a la función comunicativa que cumplen las emisiones y a la función realizativa que poseen los actos de habla emitidos por los ciudadanos.

Rawls, en lugar de centrar el estudio de la justificación en el ámbito de la moral, propone un modelo de justificación pública de la concepción política en el cual los ciudadanos, considerándose unos a otros, o teniéndose como defensores de sus propias doctrinas, se dan al ejercicio de discutir y decidir sobre temas políticos, entre ellos los constitucionales y los de justicia.

En la teoría de Rawls, las justificaciones públicas en asuntos de justicia no están ancladas en un modelo pragmático del lenguaje. No obstante, para este autor, la justificación pública, como característica de la naturaleza de la racionalidad humana, contiene las razones de los ciudadanos acerca de la justicia.

Para Rawls, los ciudadanos deben estar preparados para justificar sus acciones a otros, de manera que estas contengan sus compromisos de vivir cooperativamente con ellos (Moon, 2003). Por lo tanto, toda justificación de la justicia contiene la concepción que los ciudadanos tienen de la misma. En sociedades democráticas se espera que los ciudadanos perciban la justicia de manera justa y como representación de todos los individuos razonables. En asuntos de justicia, las justificaciones tienen tres propósitos: apoyar el régimen democrático, expresar la confianza que tienen los ciudadanos en dicho sistema y mostrar las razones por las cuales los individuos desean participar cooperativamente de este régimen (Laden, 2003).

Los anteriores propósitos ilustran por qué la razón pública es uno de los valores políticos y morales básicos de los gobiernos democráticos y muestra la importancia que tiene en estos gobiernos establecer un vínculo de confianza de los ciudadanos con las instituciones (Rawls, 1997). 
No obstante, las justificaciones de los individuos acerca de la justicia difieren en razón de sus compromisos filosóficos, religiosos y políticos; situación que lleva a que los ciudadanos no siempre logren un acuerdo total en asuntos de justicia. La divergencia y pluralidad de razones que tienen los ciudadanos acerca de la justicia refleja la diversidad y la complejidad de la sociedad. Rawls propone para las sociedades plurales unos principios de justicia ${ }^{3}$, de manera que sea posible alcanzar acuerdos razonables entre ciudadanos que aspiren a vivir cooperativamente (Laden, 2003).

Para Rawls, el ciudadano como miembro de la estructura básica de la sociedad, independientemente de la posición social o de la generación a la que pertenezca, establece los acuerdos necesarios para mantener a lo largo del tiempo la justicia para todas las personas por igual. Para Habermas, los ciudadanos comunicativamente están dispuestos a aceptar como válidas las normas morales, de manera que puedan coordinar sus acciones para establecer formas de entendimiento mutuo.

A pesar del pluralismo que pervive en la sociedad democrática, Rawls y Habermas consideran que los ciudadanos poseen una noción de justicia en la cual prevalece lo que es «bueno para todos», por encima de criterios del bien particular (Cárcova, 2003). Para estos filósofos, en sociedades definidas como democráticas y pluralistas, las decisiones relacionadas con la concepción pública de la justicia deben tomarse en condiciones de libertad y por fuera de criterios de autoridad.

Rawls y Habermas sostienen la idea de que existe una respuesta racional para los conflictos suscitados por ideas morales contradictorias. En situaciones de conflicto, los individuos deben apelar a las buenas razones de todos los afectados. Los ciudadanos ajustan y revisan sus decisiones morales plegados a las leyes y a las normas que han sido reconocidas y aceptadas por ellos. Los acuerdos entre los ciudadanos en situaciones de conflicto deben alcanzarse a través de razones que les permitan vivir juntos (Laden, 2003).

3 En la teoría de la justicia como equidad, Rawls utiliza el siguiente procedimiento para que los ciudadanos logren el consenso en sociedades plurales: se parte de una situación hipotética de posición original en la que los ciudadanos seleccionan para siempre los principios de justicia. Los miembros participan de esta elección sometidos por un velo de ignorancia con el objeto de que desconozcan su rango social, edad y sexo, entre otros aspectos que convoquen a la desigualdad. Una vez elegidos los principios de justicia se realiza la convención constitucional a la luz de los principios de justicia de que ya dispone la sociedad. Posteriormente, la sociedad promulga las leyes que la constitución admite y que los principios de la justicia requieren y permiten. Finalmente, los ciudadanos asumen el papel de jueces al interpretar la constitución y las leyes como miembros de la judicatura (Rawls, 2001). 
Frente al pluralismo que pervive en las sociedades, tanto Rawls como Habermas rehabilitaron el pensamiento de Kant, en especial la idea de que existe una respuesta racional para los conflictos suscitados por ideas morales contradictorias: debemos hacer lo que sea igualmente bueno para todos. Habermas y Rawls renovaron el planteamiento de Kant y propusieron que las decisiones frente a los conflictos se deban tomar plegados a decisiones razonables (Cárcova, 2003).

Para el investigador Laden (2003), la propuesta de Kant de lo que es razonable está presente en los presupuestos de Rawls y Habermas, en especial cuando sostienen que uno de los aspectos de la justicia es que respetemos a nuestros conciudadanos suficientemente para tratarlos como fines, ofreciéndoles razones que podamos aceptar, de manera que podamos vivir juntos.

Tanto Habermas como Rawls asumen que en las sociedades plurales, la legitimidad política se alcanza cuando las partes negocian y acuerdan un compromiso político motivado racionalmente. En una sociedad democrática encontramos la justificación pública de la justicia cuando existe un consenso razonable en el cual todos los ciudadanos se asumen como defensores de sus doctrinas comprehensivas. La justificación pública genera las condiciones para el ejercicio legítimo del poder político, propicia la estabilidad social y propende por el reconocimiento mutuo de todos los ciudadanos como libres.

Rawls propone que en la vida cotidiana existen dos formas de entender el consenso: aquel que responde a los intereses de los políticos y el que se realiza cuando los ciudadanos están dispuestos a discutir razonablemente los términos de la cooperación equitativa (Carvajal, 2000). La destreza de un político en la búsqueda de acuerdos es un ejemplo que contradice el espíritu de la justificación pública. Para Rawls, este tipo de consenso es una «política equivocada» porque no satisface el criterio de ser razonable (Apel, 2004).

Rawls establece una relación entre justificación pública y consenso entrecruzado. Este consenso se introduce con el objeto de evitar que las distintas visiones filosóficas, religiosas y morales que perviven en la sociedad, se constituyan en un obstáculo para realizar una justificación pública de la justicia. Por lo tanto, el consenso entrecruzado sirve como principio regulador (procedimental) del pluralismo razonable (Apel, 2004). 
Habermas, en su réplica a la propuesta del consenso entrecruzado, plantea la necesidad de exigir unos acuerdos de forma pública y colectiva. Para Habermas, en un mundo moderno, quien quiera alcanzar un acuerdo y propiciar el entendimiento entre hablantes con o sin opiniones divergentes, debe hacer uso de argumentos racionales. Esto significa que el lenguaje se convierte en el regulador de situaciones intersubjetivas, a partir de las cuales es posible lograr la autoescenificación del individuo y su auto-reconocimiento.

Adicionalmente, Habermas (2000) sostiene que no podemos Ilevar a cabo un consenso entrecruzado hasta que los individuos no se encuentren en disposición de adoptar un punto de vista moral independiente de las distintas concepciones del mundo que cada cual asume.

El investigador Laden (2003) sostiene que para Rawls las razones que están sobre la base de las justificaciones permiten, de un lado, conocer los motivos que tienen los ciudadanos para participar en el sistema democrático cooperativamente, y del otro, identificar la confianza que tienen estos ciudadanos en dicho sistema.

Al respecto, tenemos que la razón pública es uno de los valores políticos y morales básicos en sociedades plurales porque determina los alcances que tiene un gobierno democrático y orienta relaciones entre los ciudadanos y de estos con las instituciones (Moon, 2003).

Tanto Rawls como Habermas consideran que en la sociedad plural los ciudadanos tienen la costumbre de justificar públicamente los asuntos relacionados con la justicia. A partir de estas justificaciones, los ciudadanos expresan la valoración que tienen de las normas y las reglas, proponen mecanismos de manera que se logre el entendimiento entre los ciudadanos y exponen las razones que los llevan a reconocer las instituciones como justas, de manera que los ciudadanos se motiven a cooperar en el sistema democrático.

Para Rawls y Habermas, los ciudadanos justifican públicamente los asuntos de justicia, presentando para ello las razones objetivas y racionales que los llevan a tomar una decisión. Así pues, en estos dos autores encontramos la idea central de que en asuntos de justicia la razón tiene una función central, por lo tanto las convicciones morales en asuntos de justicia se debaten y comparten a partir del uso de justificaciones racionales y razonables (Mouffe, 1999; Carvajal, 2000). 
Giusti (2001) indica que en la teoría de la acción comunicativa, Habermas sostiene que solo son válidas aquellas normas en las que todos los afectados sean partícipes en el discurso racional. Este discurso permite que los ciudadanos, al hablar o emitir actos de habla con propósitos comunicativos, establezcan en la praxis cotidiana relaciones intersubjetivas. Para el filósofo Moon (2003), en Rawls la justificación sucede cuando todos los miembros razonables de la sociedad política presentan los argumentos que los Ilevan a entenderse con otros ciudadanos en asuntos de justicia.

Si bien Habermas y Rawls reconocen, tal como se viene exponiendo, que los ciudadanos presentan sus razones en asuntos de justicia, estos dos autores difieren en su fundamentación acerca de lo racional y de lo razonable y en su explicación acerca de los aspectos formales presentes en la justificación pública de la justicia. No obstante, ambos autores coinciden en reconocer, siguiendo los postulados de Kohlberg (1987), que los rasgos del razonamiento moral están en la característica más estructural del juicio moral: la justicia. Veamos estos tres planteamientos:

\subsubsection{Lo racional y lo razonable en la justificación en asuntos de justicia}

Para Rawls, la persona moral está constituida por dos facultades morales: ser racional y ser razonable. Los ciudadanos son racionales cuando tienen una concepción del bien y muestran, orientados bajo criterios de equidad, el interés que tienen de alcanzar los ideales que en dicha concepción han sido aceptados por los ciudadanos. Rawls asimila lo racional a la idea de que toda persona moral tiene una conciencia reflexiva que lo habilita para tener un sentido de la justicia.

Para Carvajal (2000), la facultad de ser razonable en Rawls se despliega en el espacio público y se explica a partir de dos nociones. En la primera tenemos que la persona moral posee la facultad de ser razonable porque tiene, cualquiera que este sea, un concepto de justicia (Wallace, 2001). La segunda noción de lo razonable se relaciona con la justificación pública. Para Rawls los ciudadanos que participan en la deliberación pública tienen que presentar, así no estén de acuerdo en asuntos fundamentales filosóficos de la justicia, sus acuerdos con referencia a la estructura política de su sociedad, con el objeto de regular su vida colectiva de acuerdo con los principios que han sido apoyados en la justificación pública (Laden, 2003). 
Mientras lo razonable en Rawls se refiere a la actitud de la persona dispuesta a establecer las condiciones de la cooperación social, para Habermas (2000) el término razonable se relaciona con la satisfacción de una pretensión de validez desempeñada discursivamente. En las justificaciones morales, los ciudadanos expresan distintas pretensiones de validez, entre estas: el hablante dice la verdad, los actos de los hablantes manifiestan la rectitud del hablante y el hablante expresa con sinceridad sus opiniones (Fuentes, 2003).

Según Habermas (1987), mientras las pretensiones de verdad y de rectitud son garantizadas discursivamente, es decir dando razones, la pretensión de autenticidad solo puede ser garantizada desde comportamientos coherentes. Estas pretensiones de validez pueden observarse en la racionalidad comunicativa, entendida como aquella solventación sobre proposiciones alcanzadas con criterios que posibilitan la postura crítica y el libre intercambio de argumentos. Este intercambio de argumentos está relacionado con el uso de actos de habla empleados por los sujetos con el fin de alcanzar las pretensiones de validez ajustadas a las reglas pragmáticas que hay en la argumentación (Quintero \& Restrepo, 2000).

\subsubsection{Aspectos formales presentes en la justificación pública de la justicia}

En el pensamiento de Rawls encontramos que el autor opta por el diseño de un modelo tripartito de la justificación pública de la justicia. En este modelo tripartito, la primera justificación es la pro tanto; esta se restringe al terreno de la acción política en asuntos constitucionales esenciales para definir las cuestiones básicas de justicia. Seguidamente tenemos la justificación plena, que recae en el ciudadano individual, considerado como miembro de la sociedad civil. Finalmente tenemos la justificación pública, que consiste en que todos los miembros razonables de la sociedad política comparten una justificación de la concepción política.

Rawls también opta por otros rasgos formales en la justificación pública: la generalidad, la universalidad, la publicidad y la finalidad (Nino, 1989). Estos rasgos, que están presentes en su explicación acerca de los principios de la justicia, permiten describir y entender la capacidad moral que tienen los ciudadanos para juzgar cosas como justas o injustas y para expresar los juicios de valor mediante razones. 
El investigador Nino (1989) sostiene que Rawls, en la propuesta de la posición original, con el propósito de sostener que los principios universales previstos en esta posición solo son válidos si son aceptados por todos los interesados en ciertas situaciones ideales, propone los siguientes aspectos formales: la imparcialidad, la racionalidad y el conocimiento de hechos relevantes. Para Rawls (2001), el razonamiento moral de los ciudadanos en la posición original les permite, sometidos por el velo de la ignorancia, seleccionar y juzgar los principios de justicia que en esta posición subyacen.

Por su parte Habermas, en su propuesta filosófica de la justificación pública, propone dos condiciones formales. La primera está relacionada con las reglas de comunicación que determinan el comportamiento intersubjetivo y social de los individuos. Al respecto sostiene que en situaciones de interacción comunicativa, los enunciados que tienen una fuerza moral son aquellos que se ajustan a las condiciones de la situación ideal del diálogo, explicadas en párrafos anteriores, dado que estas reglas permiten al sujeto ubicarse en un plano cognitivo interno y ponerse en el lugar del otro (descentramiento).

Para Benhabib (1991), la segunda condición formal tiene que ver con el consentimiento o aceptación de una justificación o deliberación entre todos los afectados. Los requisitos para que sea aceptada una justificación y motive racionalmente son: todos tienen derecho de participar en la deliberación, lo cual está gobernado por normas de igualdad y de simetría; todos tienen derecho de cuestionar los tópicos asignados en la conversación; todos tienen derecho de iniciar argumentos reflexivos y relevantes.

A pesar de las diferencias entre Rawls y Habermas en la explicación de sus reglas formales, sus propuestas son consideradas por sus críticos como universalistas, cognitivas y ahistóricas.

Al respecto Walzer (1993), Maclntyre (1987), Fairfield (1999) y Mouffe (1999) señalan tres críticas a los requisitos formales de la justificación pública propuestos por Rawls y Habermas. En la primera, estos filósofos sostienen que los aspectos formales están relacionadas con el universalismo, en el cual se considera que las estructuras del razonamiento de la justicia están presentes en todas las culturas, por lo tanto cualquier individuo moral-racional estaría en la capacidad de asumir, como miembro de la sociedad, una perspectiva social; se trataría de un universalismo en el que se desconoce que la acción social está mediada por las estructuras de poder vigentes en las sociedades. 
En la segunda crítica los anteriores filósofos sostienen, precisamente, que si el valor de la justicia reside en el razonamiento formal y no en el contenido, tendremos que las justificaciones públicas de los ciudadanos no responden a una sociedad históricamente determinada y lingüísticamente diferenciada.

En la última crítica, estos filósofos sustentan que el papel asumido por Habermas y Rawls es el de «inventores» y no el de intérpretes de una realidad local. A juicio del filósofo Giusti (2001), el uso de las reglas formales en las teorías éticas, como la de Rawls y Habermas, nace del interés de que en sus teorías estén incluidos todos los seres humanos. Para Walzer (1993), los representantes del universalismo, con el objeto de gobernar la vida de todos los seres de una sociedad democrática, se han dado a la tarea de idear unas reglas desconociendo el lugar que tiene el lenguaje natural en la justificación pública de la justicia.

\subsubsection{La justicia es la vía cognitiva o racional de la moralidad}

Rawls y Habermas, en su justificación acerca del carácter cognitivo de la justicia, han establecido un diálogo filosófico con la obra de Kohlberg. No obstante, los representantes de la orientación deliberativa también reconocen los aportes de Piaget (1977) en la explicación del lugar que ocupa la justicia en el razonamiento moral. Algunas hipótesis en las cuales se ha centrado el diálogo entre los representantes de la orientación deliberativa, en especial, con Kohlberg son:

- El razonamiento moral es un proceso cognitivo que nos permite reflexionar sobre nuestros valores y organizarlos en una jerarquía lógica.

- El ejercicio de la moral no se limita a raros momentos en la vida; es integrante de los procesos de pensamiento que empleamos para extraer sentidos morales a los conflictos que surgen en la vida diaria.

- El juicio moral se explica según los principios piagetianos de conflicto cognitivo y reorganizaciones secuenciales en estadios.

- El juicio moral es el factor de mayor importancia en la conducta moral.

- El cambio de estadio del juicio moral es irreversible, mientras que la conducta moral en sí es, fundamentalmente, situacional.

Para Rawls y Habermas, una definición de juicio moral se centra en las operaciones de la justicia presentes en las etapas del desarrollo propuestas por Kohlberg. Por lo tanto, para los representantes de la orientación deliberativa, la propuesta del desarrollo moral explica las cualidades formales 
de los juicios en cada etapa, independientemente de las cualidades o de los contenidos de estos juicios, en cuya valoración no siempre tienen que existir acuerdos, sino en la forma como razonamos en temas de justicia.

El investigador Retuerto (2002) muestra que las condiciones formales previstas en cada etapa del desarrollo permiten establecer distinciones entre la forma de razonamiento de una etapa a otra. Adicionalmente, la estructura lógica de cada etapa del razonamiento moral indica las condiciones de equilibrio hacia el que tiende cada aprendizaje, entre los que se incluye la justicia.

Si bien Kohlberg aporta a la explicación del carácter cognitivo de la justicia en el pensamiento de Rawls y Habermas, estos dos autores también inciden, de distinta manera, en su fundamentación filosófica de la teoría del desarrollo moral.

Así pues, Kohlberg toma del concepto de justicia como equidad, propuesto por Rawls, la idea de que los principios que un individuo escoge son aquellos que cualquier miembro de la sociedad escogería si él ignorara la posición social que iba a tener en la sociedad. Kohlberg comparte con Rawls la idea de que una vez las estructuras cognitivas maduran, las personas llegan a reconocer su lugar en la sociedad y son capaces de asumir el punto de vista de los demás y de apreciar los beneficios mutuos que tiene establecer unos términos justos de cooperación social. Por lo tanto, la adquisición del sentido de justicia se logra con el desarrollo del conocimiento y de la comprensión. Para conseguir el sentido de la justicia es preciso adquirir una concepción del mundo social y de lo que es justo e injusto.

Si bien Kohlberg reconoce el aporte de Rawls en su propuesta de justicia como equidad, destaca el papel que ha tenido Habermas en la reformulación de su teoría y en la fundamentación filosófica del estadio seis (etapa posconvencional). Al respecto Kohlberg (1992), en la fundamentación inicial de su teoría, sostenía que la psicología de la ontogénesis era una reconstrucción ética, normativa y racional de los juicios morales considerados del más alto nivel. No obstante, Kohlberg (1987), a partir del diálogo filosófico con Habermas (1984), reconoce que el desarrollo moral ofrece evidencias empíricas de los distintos estadios del desarrollo, pero no se constituye una teoría filosófico-normativa, aunque en ella se recurra a los planteamientos de la filosofía moral porque esta indica lo que idealmente «debería ser» dicho desarrollo. 
Adicionalmente Kohlberg (1992), a partir de estos diálogos filosóficos, propone «atenuar»su pretensión de haber encontrado un sexto estadio del desarrollo moral. Al respecto, afirma que es importante para la psicología continuar haciendo hipótesis que conduzcan a reconocer que los sujetos pueden llegar a un sexto estadio moral, a pesar de que los datos longitudinales de sus estudios empíricos aún no proporcionan el material necesario para verificarlo. Asimismo, Kohlberg señala la necesidad de contar con propuestas filosóficas orientadas a la fundamentación de este estadio. 


\section{CAPÍTULO II}

\section{EL SENTIDO DE JUSTICIA Y LA GRAMÁTICA DE LOS SENTIMIENTOS}

En el pensamiento de Rawls encontramos la concepción de la justicia en su fundamentación política y moral, mientras que el sentido de la justicia hace parte de su análisis acerca de los principios de la psicología moral, los cuales le permiten proceder a una explicación filosófica de la adquisición de la justicia.

El sentido de justicia para Rawls obedece a un proceso de aprendizaje adquirido gradualmente. Por lo tanto, la adquisición del sentido de la justicia depende de unas etapas de desarrollo que van avanzando de lo más sencillo a lo más complejo; etapas que están relacionadas con el desarrollo cognitivo y con la comprensión del sujeto acerca del lugar que ocupa en la sociedad, lo que equivale a tener la capacidad de asumir el punto de vista de los demás y a establecer términos justos de cooperación (Rawls, 1997).

Rawls esboza en tres etapas del desarrollo moral el curso que ha de seguir la adquisición del sentido de justicia y los sentimientos morales que están adscritos a dichas etapas. Estas son: moral de la autoridad, moral de la asociación y moral de los principios.

Estas tres etapas del desarrollo no están determinadas por mecanismos innatos; tampoco deben ser entendidas como una descripción estandarizada del desarrollo individual moral. Para Rawls, las etapas de desarrollo proporcionan una comprensión del proceso evolutivo moral desde una concepción filosófica, aunque para ello recurra a leyes psicológicas. 
En la concepción rawlsiana, el sentido de la justicia se explica desde su doble naturaleza: cognitiva y emotiva. El sentido de la justicia en su naturaleza cognitiva da cuenta de la capacidad que desarrollan intelectualmente todas las personas, mientras que el carácter emotivo explica la naturaleza social del ser humano y guía la realización de acciones morales motivadas por el amor, la amistad y la confianza (Agra, 1985).

En efecto, en la etapa moral de la autoridad el niño no está en capacidad de justificar los conceptos, por lo tanto no duda de los mandatos paternos porque estos provienen de sentimientos de cariño y de confianza. Así, el incumplimiento o la desobediencia a las órdenes generan en el niño el sentimiento de culpa, el cual surge del quebrantamiento de una norma establecida en el marco del respeto y la confianza, y no sobre la base de las amenazas que exigen su cumplimiento (Rawls, 1997).

La etapa moral de la autoridad está regida por la primera ley psicológica, en la cual Rawls sostiene que las instituciones familiares son justas y que los padres manifiestan el amor a sus hijos preocupándose por su bien. Asimismo los niños reconocen el amor que sus padres profesan por ellos, lo que los lleva a expresarles su amor.

En esta primera etapa encontramos el sentimiento de culpa, el cual expresa el carácter relacional que tienen los sentimientos morales. En efecto, la culpabilidad respecto a las autoridades es un sentimiento relacional que surge del temor al enojo y a sentirse indigno de gozar del reconocimiento de aquellos con los que comparte ideales normativos comunes. Este sentimiento de culpa también está asociado a los principios del derecho, porque la desobediencia recae en el incumplimiento de una norma que goza de validez social.

En la segunda etapa, la moralidad de la asociación ubica al individuo compartiendo las normas sociales y morales que han sido establecidas en las diversas asociaciones a las que él pertenece (familia, escuela, sociedad, entre otras). Esta moral de la asociación contempla los derechos y los deberes, las virtudes y los ideales de una persona virtuosa y moral establecidos en la estructura de la sociedad. Esta etapa responde a la segunda ley psicológica en la cual, según Rawls, encontramos los sentimientos de simpatía, amistad y confianza respecto a los otros con quienes el individuo se halla asociado y quienes a su vez cumplen con sus deberes y obligaciones. 
La moral de la asociación depende del desarrollo de las facultades intelectuales, en el sentido en que el individuo está en capacidad de exponer sus puntos de vista, interpretar otras perspectivas sociales y morales y tomar decisiones guiado por sus aprendizajes morales. En esta etapa, el sentimiento de simpatía hacia otros le permite su incorporación y permanencia en la estructura de la sociedad, así como actuar de forma justa y desarrollar sentimientos de amistad, lealtad y confianza.

La carencia del sentimiento de simpatía pone de manifiesto la falta de lazos de amistad y de confianza entre los miembros de la sociedad. Al igual que en la primera etapa, en la moral de asociación también encontramos el sentimiento de culpa. Este sentimiento de culpa se manifiesta de diversos modos: inclinación a la reparación de los daños causados; reconocimiento de que el castigo y la censura son justos; aceptación de que la falta es una vulneración a una norma moral establecida bajo criterios de respeto y confianza.

Para Rawls, en esta etapa, el no reconocimiento social y la falta de respeto como miembro de la sociedad, así como la imposibilidad de despertar entre los miembros el sentimiento de simpatía, genera en los ciudadanos los sentimientos morales de resentimiento e indignación.

La última etapa relacionada con la moral de los principios es la más compleja, porque significa el conocimiento y la aplicación de los principios de la justicia. A esta moralidad se llega una vez los individuos tienen actitudes de amor, confianza y establecen relaciones guiados por sentimientos de amistad y de fidelidad. La adquisición de estos sentimientos Ileva a que los ciudadanos sean beneficiarios de instituciones justas, las cuales tienden a generar el sentimiento de justicia.

En esta tercera etapa encontramos dos conceptos complementarios: el sentido de la justicia y el sentimiento de la justicia. El primero supone la aceptación de las instituciones, mientras que el sentimiento de la justicia se manifiesta de dos maneras. La primera tiene que ver con el interés de los individuos por mantener los ordenamientos que favorecen el bien común. La violación de este sentimiento de justicia lleva a que los individuos se sientan culpables por no cumplir con los derechos y las obligaciones, guiados por un lazo especial de simpatía. La segunda está relacionada con el deseo de trabajar a favor de la implantación de instituciones justas, lo que significa tener la voluntad de fomentar o reformar las instituciones, de manera que estas se orienten bajo los criterios de justicia como equidad. 
En esta última etapa, Rawls se interroga acerca de las razones por las cuales los principios morales comprometen la naturaleza emotiva de los ciudadanos. Entre otros argumentos, Rawls sostiene que los principios de justicia representan pluralidad de intereses, los cuales están orientados por el sentimiento de hacer un bien a la humanidad. Asimismo, estos principios orientan el deseo de hacer lo que es recto y justo; en consecuencia, los principios promueven los sentimientos de rectitud y de justicia. Un último argumento tiene que ver con la idea de que los principios adquieren la forma de amor a la humanidad.

El contenido de la moral de los principios no responde a contingencias sociales o naturales; este se ajusta a una concepción del derecho y de la justicia comúnmente aceptada, concepciones que indican la naturaleza racional, libre e igual de los individuos (Agra, 1985).

En esta última etapa se aprecia la incorporación del individuo a unas relaciones más complejas que las establecidas en la etapa de la moralidad de la asociación. El propósito de Rawls en esta última etapa es plantear relaciones entre el individuo con las instituciones sociales, con otros individuos y con la sociedad bien ordenada. La ley psicológica propuesta en esta etapa señala que una vez generadas las actitudes de amor y confianza, y los sentimientos de amistad y lealtad incorporados en las etapas anteriores, y reconocidas las instituciones como justas, el individuo adquiere el correspondiente sentido de justicia (Agra, 1985).

En la obra de Rawls -la teoría de los sentimientos morales, iniciada en 1963 y reformulada en 1977 e inspirada en los trabajos de Piaget y Kohlberg- prevalece el interés por presentar una construcción psicológica del concepto de justicia como imparcialidad, en la cual el ciudadano como persona moral es la «piedra moral» de la concepción de justicia (Mejía, 1994).

Para Rawls, una persona carente del sentido de la justicia e incapaz de actuar tal como la justicia lo requiere, no solo carece de lazos de amistad, afecto y confianza mutua, sino que es incapaz de experimentar enojo e indignación. En otras palabras, una persona carente de un sentido de justicia carece de ciertas actitudes y capacidades fundamentales, incluida la noción de humanidad. En consecuencia, los sentimientos morales son una parte normal de la vida cotidiana, y carecer de estos es perder el sentido de amor a la humanidad y el deseo de contribuir al bien común, orientado por los principios de la justicia. 
La propuesta de Rawls de la construcción psicológica de los sentimientos morales, pasando de unos estadios a otros, coincide con la propuesta de Habermas acerca de la existencia de una lógica inherente al desarrollo del razonamiento moral, en la cual se incluye la sensibilidad moral por el carácter cognitivo que en ella reside.

Si bien Habermas no presenta unas etapas del desarrollo de los sentimientos morales en las cuales el aprendizaje defina el paso de una a otra, el filósofo coincide con Rawls en que el conocimiento moral es producto de un aprendizaje. Para Habermas, en este proceso de aprendizaje moral el individuo desarrolla, en el tránsito de una etapa a otra, modos más adecuados de razonamiento y una capacidad más compleja para asumir roles. Así pues, tanto Rawls como Habermas consideran que en cada etapa encontramos tanto el desarrollo cognitivo como el social, aunque Habermas también ubica en estas etapas tipos de acción de naturaleza comunicativa.

Habermas y Rawls consideran que cada nueva etapa contiene a su predecesora. Para los dos autores, en etapas superiores se tiene mayor capacidad de comprensión, explicación e interpretación de los fenómenos morales que en etapas inferiores. En consecuencia, la última etapa, Ilamada en Rawls moral de principios y en Habermas posconvencional, es más adecuada que las antecesoras.

Rawls propone el sentido de la justicia a partir de las dimensiones cognitiva y emotiva, y Habermas plantea la idea de justicia reconociendo estas dos dimensiones e incorporando una nueva, la comunicación, entendida como fundamento de la ética, la moral y el derecho.

En efecto, para Habermas la idea de justicia se adquiere mediante una lógica de desarrollo moral -como lo propone Kohlberg-, la cual se acompaña de una lógica comunicativa que tiene como propósito, tal como se ha indicado en anteriores capítulos, alcanzar el entendimiento entre hablantes con opiniones divergentes, así como motivar racionalmente a un interlocutor a participar de una práctica comunicativa libre de compulsiones.

Para Habermas (2002), en estas lógicas de desarrollo moral y comunicativo encontramos inicialmente una idea de justicia concreta inserta en los mundos de la vida a partir de la cual se realizan juicios morales particulares. A medida que se va asimilando la creciente complejidad social y que los individuos van pasando de cuestiones de aplicación a cuestiones de fundamentación, se va adquiriendo una idea de justicia cada vez más abstracta 
hasta convertirse en un concepto procedimental en el cual solo pueden pretender validez aquellas normas que podrían encontrar la aprobación de todos los afectados.

En estas dos lógicas del desarrollo tanto moral como comunicativo, encontramos la sensibilidad moral, la cual es fundamental para detectar y vivenciar los conflictos morales presentes en el mundo de la vida y para plantear posibles soluciones a dichos conflictos (Hoyos, 1995).

En efecto, Habermas (2002) sostiene que los sentimientos morales contribuyen a la regulación de los conflictos presentes en la interacción de la vida cotidiana, porque a partir de ellos establecemos nuestros juicios de valor y resolvemos discursivamente las convicciones normativas que no gozan de una validez general.

Por lo tanto, para Habermas (2002) los sentimientos morales, que tienen un contenido cognitivo porque se expresan mediante juicios de valor, y que poseen una estructura comunicativa porque permiten tematizar, dar razones, motivos y explicaciones, se constituyen en señales de alerta porque indican la vulneración del orden moral que goza del reconocimiento recíproco.

En el pensamiento de Habermas, los sentimientos morales expresan, especialmente, el grado de vulneración de las normas, revelan la dimensión moral de un agravio padecido y denuncian el ataque contra cualquier «esperanza normativa» que tenga validez social (Habermas, 2004).

Además del carácter cognitivo y comunicativo, los sentimientos morales poseen en el pensamiento de Habermas tres rasgos relacionados entre sí (Habermas, 1994). El primero de estos, en el cual coincide con Rawls, tiene que ver con el carácter relacional de los sentimientos morales. Habermas sostiene que los sentimientos morales son vinculantes intersubjetivamente. En tal sentido, los sentimientos morales, que hacen parte del mundo de la vida o de la sociedad civil, permiten a los sujetos morales asumir una actitud participativa, la cual devela tres perspectivas de la relación social: la de participante como «paciente», como «observador» y como «agente» (Hoyos, 1995).

La naturaleza relacional de los sentimientos conduce al segundo rasgo referido a la praxis cotidiana o esfera de las experiencias morales. Los sentimientos de indignación, resentimientos y culpa, solo se dan en relaciones 
interpersonales en las cuales los sujetos morales que participan en la esfera de acción social realizan un determinado comportamiento moral, el cual lesiona a otro. Para Habermas es en la praxis cotidiana en donde se producen las lesiones y los agravios ante los cuales los sujetos reaccionan con sentimientos morales.

El tercer rasgo de los sentimientos morales, vinculado estrictamente con los otros dos rasgos, muestra el lugar que ocupa en la fenomenología de la moral de Habermas el quebrantamiento de las normas morales. Si los sentimientos morales están implicados en las relaciones internas y afectan la praxis cotidiana, lo que se vulnera no son las relaciones afectivas y personales de un sujeto moral; la vulneración está dirigida contra la validez de las normas morales.

Los sentimientos morales superan el particularismo porque la vulneración no es hacia una persona en una situación dada, sino contra los mandatos, las obligaciones y los derechos que han sido legitimados socialmente.

La anterior fundamentación de la fenomenología de los sentimientos morales, Habermas la acompaña del análisis de los sentimientos morales de indignación, resentimiento y culpa propuestos por Strawson (1974). El sentimiento de indignación es la reacción que tenemos contra un agravio que se produce contra otro, el cual es objeto de censura. Habermas (1994) sostiene que cuando la injuria o la vulneración padecida no se «repara», la reacción inequívoca se fortalece e intensifica hasta convertirse en un profundo resentimiento.

La sensación de resentimiento, que lesiona la integridad, significa la vulneración de un derecho moral. Habermas indica que el resentimiento moral reside en un ataque contra una norma moral que tiene validez, no solamente para ego y alter sino para todos los participantes de un grupo social, y también para todos los sujetos responsables del cumplimiento de las normas.

Por su parte, el sentimiento de culpa que se da en quien participa en la acción mediante el quebrantamiento de una norma, se asume, aparentemente, como un sentimiento carente de intersubjetividad o de alguna exigencia recíproca. No obstante, Habermas (1994) indica que el culpable puede justificarse solicitando disculpas. En consecuencia, la justificación de una culpa y la petición de disculpas evitan el paso de la indignación al resentimiento. 
En Habermas, el sentido de la justificación moral consiste en no perder de vista que la red de sentimientos morales instalada en la praxis cotidiana invoca al enjuiciamiento de la vulneración de las normas y de los mandatos que tienen reconocimiento social. En consecuencia, los sentimientos morales, denominados por Habermas negativos, se introducen en las justificaciones morales porque se explicitan en forma de juicios de valor.

Al respecto Habermas busca, a partir de un principio puente como principio metodológico, pasar de sentimientos morales a juicios morales. En otras palabras, Habermas propone un principio que nos permita pasar de experiencias morales, en las que se incluyen los sentimientos, a juicios (Hoyos, 1998b).

Este principio puente, que es la ética comunicativa, surge al replantear la formulación del imperativo categórico de Kant. Kant propone: «obra solo según aquella máxima que puedas querer que se convierta en ley universal». Por su parte, Habermas reformula la formulación de Kant de la siguiente manera: «en lugar de proponer a todos los demás una máxima como válida y que quiero que sea como ley general, tengo que presentarles a todos los demás mi máxima con el objeto de que comprueben discursivamente su pretensión de universalidad» (Habermas, 2000).

Por lo tanto, el imperativo categórico kantiano es un principio de justificación que distingue como válidas las normas de acción universalizables. Las normas que gocen de justificación moral tienen que quererlas todos los seres racionales. En la ética del discurso, solo pueden tener validez aquellas normas que tienen el reconocimiento de todos los afectados como participantes de un discurso práctico. Esta validez se alcanza cuando los individuos en situaciones de deliberación pública presentan sus argumentos a otros comunicativamente.

En consecuencia, en la orientación deliberativa, los sentimientos morales tienen un contenido proposicional, lo que conduce a que los sujetos morales siempre tengan que proceder a la justificación moral, es decir, a presentar las razones y los motivos que los llevan a rechazar la vulneración de una norma moral y a expresar la indignación ante el dolor de una víctima humillada o despreciada. 


\section{INVESTIGACIONES ACERCA DE LA VIDA CON LOS OTROS}

Se presentan los resultados de las siguientes investigaciones, atendido a sus macos de referencia y hallazgos empíricos.

- Itinerarios de los discursos en la reconstrucción de la lógica moral en el joven universitario.

- Justificaciones de jóvenes universitarios y jóvenes desplazados acerca de la concepción de justicia.

- Los sentimientos morales y políticos en el ejercicio ciudadano: ¿un asunto de formación?

- Conflicto armado e impacto en la escuela: ejercicio ciudadano.

\subsection{Itinerarios de los discursos en la reconstrucción de la lógica moral en el joven universitario ${ }^{1}$}

En el presente proyecto de investigación se propuso como problema de investigación y objetivo general reconstruir la lógica del desarrollo moral del joven universitario acerca de la justicia a partir de sus justificaciones. Se plantearon como objetivos específicos, identificar los tipos de juicio y de acción moral asociados a sus actos de habla, establecer sus ideas de justicia, y determinar las pretensiones de validez que subyacen a su ética

\footnotetext{
1 Este proyecto de investigación fue financiado por COLCIENCIAS (1999-2000). Directora: Marieta Quintero. Investigadores: Bibiana Restrepo y William Sánchez.
} 
discursiva. Para ello, se analizaron los actos de habla realizativos ${ }^{2}$ relacionados con las promesas.

En la definición de la lógica del juicio moral del joven universitario, para el caso del presente estudio, se reconoció la relación y el vínculo estrecho que existe entre las perspectivas sociales, los procedimientos argumentales, las estructuras cognitivas y las etapas morales.

Para definir las etapas del juicio moral de los jóvenes universitarios, Piaget y Kohlberg resultaron valiosos en el sentido en que estos psicólogos de la moral, desde sus estudios empíricos, establecieron para cada nivel del desarrollo moral una serie de características cognitivas, en el caso del primer autor, y morales y sociales, en el caso del segundo investigador. Sin embargo, estos aportes acerca del juicio moral han sido ampliamente conocidos y adoptados en proyectos de investigación educativa desde finales de los setenta y principios de los ochenta hasta el presente. A partir de la década de los noventa hasta nuestros días encontramos los estudios Ilamados neokholberianos, desarrollados por Rest, J. (1979-2000) y Lind, G. (2008).

Los estudios de Piaget han sido retomados en las investigaciones educativas y psicológicas para dar cuenta de los procesos cognitivos. En menor grado, para comprender el desarrollo moral. En este estudio sus preguntas acerca de cómo se llega a la conciencia de la norma, de qué manera se practica, cuándo puede ser puesta en cuestión una norma y de qué manera pueden participar los individuos en su construcción, fueron adoptadas para comprender el juicio moral y la manera como se construye la conciencia moral.

En el presente proyecto podemos decir que el estadio superior del desarollo moral propuesto por Kohlberg no es solamente una construcción filosófica separada del mundo real, tal como lo enuncian Gilligan (1985), sino la opción de encaminar los esfuerzos educativos a promover la autonomía en los jóvenes, de manera que desarrollen su capacidad, entre otras, para evaluar aquellos juicios y acciones morales regidos por criterios de utilidad y recompensa, propios de un estadio preconvencional.

En esta investigación también resultaron valiosos y pertinentes los desarollos realizados por Habermas respecto a las lógicas de la evolución de la

2 Es preciso recordar que Austin denomina realizativos a los enunciados que al mismo tiempo que se emiten, expresan una acción. Entre estos tenemos: bautizar, aconsejar, prometer, entre otros. 
conciencia moral y de la argumentación o acción comunicativa. En particular, la complementariedad que propone entre etapas cognitivas y modos de interacción social con tipos de acción comunicativa.

Adicionalmente, el pensamiento de Habermas permitió entender que, en el desarrollo de la moral, el tránsito de una etapa a otra es el resultado, entre otros, del proceso de aprendizaje, entendido en el marco del tipo de resoluciones que el individuo y la sociedad están en capacidad de realizar.

En términos metodológicos, para dar cuenta de las etapas de desarrollo del juicio moral en las cuales se encuentra el joven universitario y de las prácticas discursivas vinculadas a estas, se seleccionaron como unidades de análisis los actos de habla referidos a la justicia, las normas, la confianza y los compromisos que los jóvenes asumen consigo mismos y con los demás.

La población de este estudio estuvo constituida por 108 estudiantes de primer semestre de pregrado de instituciones de educación superior del sector público y privado de la ciudad de Barranquilla, cuyas edades oscilaron entre los 16 y los 18 años.

\begin{tabular}{|l|l|l|}
\hline \multicolumn{1}{|c|}{ CATEGORÍA } & SUBCATEGORÍA & \multicolumn{1}{c|}{ INDICADORES } \\
\hline $\begin{array}{l}\text { Desarrollo moral: } \\
\text { la Justicia }\end{array}$ & Normas & $\begin{array}{l}\text { Reconocimiento y respeto por las nor- } \\
\text { mas establecidas en su círculo ético. } \\
\text { Reconocimiento y respeto por las nor- } \\
\text { mas establecidas en la esfera de la vida } \\
\text { pública. }\end{array}$ \\
\hline & $\begin{array}{l}\text { Confianza y } \\
\text { compromisos }\end{array}$ & $\begin{array}{l}\text { las promesas, pactos y juramentos } \\
\text { quealiza. }\end{array}$ \\
& & $\begin{array}{l}\text { En las promesas, pactos y juramentos } \\
\text { quéximos y en la esfera pública. }\end{array}$ \\
\hline
\end{tabular}

Como categoría de análisis central se adoptó la justicia. Veamos la relación entre esta categoría con sus subcategorías.

Para resolver el problema de investigación se propusieron como estrategias de recolección de información la entrevista y las sesiones en profundidad. La entrevista fue definida como un proceso dialogal en el que intervienen dos o más personas (entrevistador y entrevistado). Esta trasciende el modelo de cuestionario, que se soporta en la relación pregunta y respuesta. 
Esta entrevista permitió acceder a través del discurso o justificaciones de los jóvenes a la lógica de su desarrollo moral. Con la entrevista individual se establecieron los primeros acercamientos comunicativos con los informantes. Estos resultados abonaron el terreno para ampliar de forma sistemática, en las sesiones de profundidad, las justificaciones de los jóvenes acerca de la justicia.

La información resultante se analizó utilizando la técnica de análisis de contenido. En este tipo de técnica se concibe que toda acción humana es eminentemente expresiva; en tal sentido, se manifiesta a través de un lenguaje. En términos de Navarro y Díaz (1994), los diversos modos de la expresividad humana se organizan como lenguajes, entendiendo este concepto en el sentido amplio. Esta técnica de carácter cualitativo permitió el acceso a los procesos de significación inmersos en las justificaciones morales.

En el análisis de contenido, las expresiones morales de los jóvenes se organizaron a partir de un corpus textual, el cual dio lugar a la interpretación semántica y pragmática de los discursos. ${ }^{3}$ Los resultados obtenidos en este proceso de sistematización fueron sometidos a un examen intertextual que consistió en un análisis al interior de los discursos para determinar la coherencia y la cohesión de los mismos. Los resultados dados en este primer tipo de análisis (intertextual) se dieron a conocer a los grupos para ampliar la red de significación. Seguidamente, las unidades básicas de relevancia o significación encontradas en los distintos corpus fueron sometidas a interacción o diálogo con el contexto o realidad social educativa. Este diálogo, conocido como extratextual, fue la base para conocer las redes de significación de las justificaciones en asuntos de justicia.

Algunos resultados. Las justificaciones proferidas por los jóvenes en las entrevistas y en la sesión en profundidad, mostraron que estos consideran que las reglas asociadas a la justicia se deben seguir al píe de la letra, pues su contenido está relacionado con lo bueno y lo justo: «la justicia es aplicar la justicia aunque a otros no les parezca, pues ella es así». Todos debemos seguir la justicia, hay que «cumplir con las normas y las reglas».

3 En este estudio se realizó una distinción entre semántica y pragmática. Mientras la primera se ocupa de los aspectos del significado que se le atribuyen a las estructuras lingüísticas, la segunda se ocupa de la intención del hablante, el contexto lingüístico y extralingüístico en el que usan las expresiones verbales. 
Esta justificación acerca de la norma no refleja profundidad en los modos de razonamiento y argumentación de los jóvenes universitarios. Esto se confirma en la restricción de la norma a su valoración como buena en sí misma, sin que se someta a criterios de interpelación desde unos principios o máximas de acción provenientes de la esfera social o de los aprendizajes de los mismos jóvenes. La valoración de la justicia sin ningún tipo de restricciones, impide que los jóvenes deliberen públicamente acerca de los asuntos de la justicia.

Esta posición, en la que la norma no es posible de ser objeto de rechazo o crítica por parte de los grupos sociales, podría ser asociada con un tipo de responsabilidad social limitada a cumplir las reglas al pie de la letra. En consecuencia, los sujetos estarían desprovistos de su capacidad argumentativa y crítica, y con ello, reducido su potencial participativo y deliberativo en problemas referidos a la vida ciudadana. En otras palabras, la esfera de la vida pública se torna débil.

Otras justificaciones de los jóvenes vincularon la norma con la justicia formal o con el derecho positivo. Así, infringir la justicia es hacerse acreedor a una pena o condena. Las normas vinculadas con la justicia formal son asumidas más como derechos y menos como deberes. En menor posicionamiento encontramos justificaciones asociadas a la restauración de los daños ocasionados. Así, más que el castigo al que infringe la norma, los jóvenes indicaron la importancia que tiene en la vida comunitaria propender por sanciones consideradas moralmente obligatorias, como el perdón y el arrepentimiento. Esta justicia permitiría que las partes en conflicto -víctima y victimario- y la misma comunidad, buscaran mediaciones y soluciones pacíficas.

Con poca frecuencia se encontraron justificaciones que propendieran por una justicia distributiva, en la cual los miembros de la sociedad se sintieran regulados por una justicia orientada al bien común. En sentido amplio podríamos decir que esta justicia está relacionada con el reparto de bienes, cargas empleos-beneficios en razón de los méritos y las capacidades, pero no de forma utilitarista. En términos de Rawls (1997), criticando a los seguidores del utilitarismo en asuntos de justicia, indica que no se trataría de una justicia en la que un individuo disfrute viendo a otras personas en una posición de menor privación. Al contrario, la justicia distributiva significa que los ciudadanos se saben capaces de actuar y juzgar según las reglas establecidas en su comunidad y que desean que también otros actúen de 
igual modo. Esto exige un sistema de cooperación planeado para promover el bien común.

Los enunciados de los jóvenes acerca de lo justo, los podemos entender en tres sentidos: en el primero de ellos, es justo aquel que juzga sus relaciones con el prójimo como juzgaría las relaciones de dos personas extrañas: "actúo con imparcialidad, independientemente de las circunstancias, las personas y las situaciones» $y$ «tomo decisiones que no afecten a nadie».

Otro sentido de lo justo para los jóvenes se evidencia en aquellas personas que no se dejan llevar por ningún favor, ningún odio preexistente o por un estado emocional que no permita ajustarse al justo: "percibir y hacer ver los errores a los demás», "no dejarse llevar por la influencia de la persona que se está juzgando», "analizar pacientemente las situaciones» y «soy capaz de asumir mis errores».

El último de los sentidos de lo justo es de carácter formal, es decir, relacionado con el derecho. Para los jóvenes, las personas justas actúan según lo estipulado por la ley. En palabras de los jóvenes, para ser justo o actuar de forma justa es necesario ser «imparcial», «equilibrado», «sincero», «responsable»y «firme», entre otros.

Las acciones personales que el joven considera como justas se restringen o limitan a procesos de interacción con el otro, circunscritos al aquí y al ahora sin trascender a situaciones generalizables (sistemas sociales). Lo anterior, como lo señala Piaget, parece ser el resultado de la ausencia de «una regla colectiva producto sui generis de la vida en común», necesaria para que exista auténtica reciprocidad.

Entre los aspectos comunes a los criterios de justicia esbozados por los jóvenes, tenemos en primer lugar una valoración de la justicia restringida a los marcos de acción circunscritos a sus experiencias o situaciones vividas por quienes hacen parte de su ámbito familiar y social cercano. En segundo lugar, la búsqueda del premio o evitar la sanción parecen ser las razones de su apego a un sistema de valores en el cual la idea de justicia que se tiene, se mueve más en el ámbito de la compensación que en el campo del reconocimiento de un sistema de principios. Por último, tenemos la idea de justicia entendida en términos de igualdad de oportunidades.

Otro hallazgo en este estudio fue reconocer que para los jóvenes no todas las justificaciones comportan el carácter de realización moral. Por ejemplo, 
la realización de un acto de promesa (subcategoría e indicador de análisis) no pareciera implicar el imperativo de cumplimiento.

El joven exige que se cumplan las promesas cuando:

«Deseo obtener algo», «quiero ganarme la amistad de alguien», "son para mi bienestar», "es importante para mí», «necesito de algo muy importante», "siento que me pueden afectar», «me han prometido algo que quiero que se cumpla» $y$ «en dificultades», entre otros.

Nótese que en cada uno de estos enunciados los intereses son personales, de manera que no existe el reconocimiento del otro. Esta misma interpretación teleológica e individualista a la que se reducen los enunciados en los que el joven exige que se cumplan las promesas, se ajusta a las circunstancias en las que el joven realiza promesas. El joven hace promesas cuando:

«Necesito que me crean», «para que confíen en lo que estoy diciendo», «cuando no me creen», «quiero ganarme la amistad de alguien», «es para mi beneficio», "quiero llevar a cabo un fin», "deseo obtener algo», "deseo asegurar algo», "me encuentro insegura de cumplir o de que me cumplan», «quiero quedar bien» y «cuando estoy en apuros o cuando cometí algún error».

Los juicios o razonamientos acerca de las promesas no se ajustan al imperativo categórico Kantiano «actúa solo según aquella máxima por la que al mismo tiempo puedas querer que ella sea ley universal». Nos encontramos frente a lo que se denomina enunciados de promesa falsa, los cuales tienen como consecuencia que en la esfera pública, estos no se reconozcan como criterios de autoregulación entre los miembros de la sociedad o como acuerdos normativos. Así, estas promesas se despojan de los criterios de sinceridad y voluntad. De esta manera las promesas pierden su carácter moral. En consecuencia se alza un muro en la sentencia moral y política que señala que existe un vínculo entre lo que «hacemos cuando decimos». Recordemos que los compromisos que adquirimos cuando realizamos pactos, promesas y juramentos, hacen parte de este tipo de lenguaje moral.

La interpretación de los compromisos en los pactos, las promesas y los juramentos -en términos generales- nos lleva a reconocer que la mayoría de los jóvenes los realizan en el plano de su vida íntima (papá, mamá, esposa, novio). Algunos jóvenes ven el pacto, la promesa y el juramento como el mecanismo de presión al que deben acudir cuando: (1) requieren coaccio- 
nar al otro para que cumpla ante un compromiso o acuerdo previamente establecido; (2) necesitan que se les crea o que confíen en ellos en una situación de conflicto.

Sin embargo, no siempre el acto de pactar, prometer y jurar implica, según los jóvenes, el compromiso de su cumplimiento. En efecto, las distintas emisiones de los jóvenes relacionadas con el pacto, la promesa y el juramento no se ajustan a las tres condiciones previstas por Searle (la intención, la relación lenguaje-mundo y la sinceridad). Esta podría ser una de las explicaciones a la creencia, arraigada, de que lo que decimos no es lo que hacemos.

Los pactos, las promesas y los juramentos de igual manera son acuerdos morales mutuos y requieren, para su realización, tener la intención de cumplirse. Los resultados del presente estudio nos señalan que los compromisos se ajustan a intereses egocéntricos y a situaciones de obligación. En consecuencia, los actos de habla relacionados con los pactos, las promesas y los juramentos realizados por los jóvenes, no responden a los principios que rigen la propia voluntad, característica esencial para alcanzar la mayoría de edad (Kant, 1973).

El tema de los compromisos podría hacer sustentar que los jóvenes no son autónomos en tanto no se ha logrado el reconocimiento de sí mismo y el compromiso que se tiene con el otro. Los jóvenes no se ponen en escena o no son sinceros en sus compromisos debido a que en ellos parece primar el carácter instrumental y persuasivo que poseen los términos éticos por encima de los compromisos que se adquieren cuando realizamos acciones morales como pactar, prometer y jurar.

\subsection{Justificaciones de jóvenes universitarios y jóvenes desplazados acerca de la concepción de justicia ${ }^{4}$}

En el estudio, las justificaciones morales se entendieron como aquellas palabras y conjuntos de oraciones con las cuales alguien, en nuestro caso el joven, valora determinadas acciones y normas como «moralmente buenas» o «moralmente malas». Por lo tanto, en esta investigación la justificación moral y política se entendió como un saber en el cual se precisa conocer

4 Estos son algunos resultados de la investigación Justificaciones de jóvenes universitarios y jóvenes desplazados acerca de la concepción de justicia, realizada con la orientación de Eloísa Vasco y financiada por COLCIENCIAS, CINDE-Universidad de Manizales, 2006. 
en qué consiste el significado de una justificación moral y cuál es su validez. El significado de las expresiones morales y la validez de las mismas resultaron complejos, entre otras razones, porque las justificaciones morales y políticas de los jóvenes, en especial en asuntos de justicia, dependen de los sistemas de creencias y de los procesos de interacción social. Esta complejidad también radica en que a partir de las justificaciones morales y políticas, los jóvenes otorgan significado al sistema de reglas dadas en la esfera pública y valoran sus propias acciones morales, así como las que realizan los miembros que hacen parte de su sistema social.

En tal sentido, cuando los jóvenes justificaban los asuntos relacionados con la justicia, las acciones, las normas morales, los sujetos y las instituciones valoradas como justas e injustas, en buena medida deliberaban, es decir, exponían sus razones e intercambiaban sus puntos de vista. Así pues, en sus justificaciones, los jóvenes presentaron discursiva y públicamente su concepción de justicia, sin desconocer sus experiencias de aprendizaje, sus vivencias culturales y su tradición (Rawls, 1997).

La pregunta y los objetivos de investigación se orientaron a conocer las concepciones de justicia que están presentes en las justificaciones de jóvenes universitarios y jóvenes desplazados, las orientaciones que subyacen en estas, los modos de razonamiento, las pretensiones de validez con referencia a lo que es ser justo e injusto, las deliberaciones acerca de las normas y las leyes, y las valoraciones que tienen estas poblaciones de las instituciones que representan la justicia; se consideró que el enfoque de investigación que más se ajustaba era el diseño de caso múltiple o colectivo de dos casos.

Se empleó como estrategia de interpretación de las entrevistas individuales y en profundidad, el análisis de contenido entendido como estrategia cualitativa, cuyos procedimientos tenían como objetivo para el investigador en este estudio: a) plantear preguntas orientadas a conocer la superficie textual de las justificaciones de los jóvenes acerca de la justicia; b) asumir las justificaciones de los jóvenes en asuntos de justicia como expresiones simbólicas; c) formular inferencias que permitieran establecer comparaciones entre las poblaciones elegidas; d) producir un metatexto acerca de la justificación de los jóvenes universitarios y desplazados en temas de justicia como resultado del análisis del corpus textual; e) interpretar la complejidad del concepto de justicia expresado por los jóvenes participantes en el estudio. 
Se seleccionó esta técnica porque las estrategias y procedimientos de análisis tienen como fundamento el lenguaje (justificaciones) en sus dimensiones simbólica e intersubjetiva y en su naturaleza social, fundamentos que eran compatibles con los presupuestos teóricos del presente estudio -teorías deliberativas y psicología moral- y con los objetivos del mismo.

En este estudio, la población estuvo constituida por 15 jóvenes ubicados en contextos universitarios y por 15 jóvenes ubicados en espacios urbanos «provisionales» en el departamento de Cundinamarca y en el Distrito Capital.

\subsubsection{Categorías y sub-categorías de análisis}

En este estudio la categoría de análisis elegida fue la justificación de la justicia, y para proceder a su interpretación y comprensión, se eligieron las siguientes subcategorías: concepciones de la justicia y orientaciones, modos de razonamiento, pretensiones de validez e instituciones políticas y sociales.

\begin{tabular}{|c|c|c|}
\hline CATEGORÍA & SUBCATEGORÍA & INDICADORES \\
\hline \multirow[t]{2}{*}{$\begin{array}{l}\text { Justificación en } \\
\text { asuntos de justicia } \\
\text { y orientaciones }\end{array}$} & \multirow[t]{2}{*}{$\begin{array}{l}\text { Juicios morales y } \\
\text { políticos }\end{array}$} & $\begin{array}{l}\text { Justificaciones: orientación intuicio- } \\
\text { nista } \\
\text { - Las personas tenemos una facultad } \\
\text { especial innata por medio de la cual } \\
\text { conocemos lo justo y lo injusto, lo } \\
\text { bueno y lo malo. } \\
\text { - Ninguna obligación moral es univer- } \\
\text { sal, sino que dependen de situaciones } \\
\text { prácticas naturales; no se requieren } \\
\text { procesos de aprendizaje. } \\
\text { - Toda norma es buena en sí misma. }\end{array}$ \\
\hline & & $\begin{array}{l}\text { Justificaciones: orientación emotivista } \\
\text { - Los predicados éticos expresan los } \\
\text { sentimientos o actitudes emociona- } \\
\text { les. } \\
\text { - Las convicciones éticas son actitudes } \\
\text { personales. } \\
\text { - El lenguaje moral tiene como finalidad } \\
\text { influir en la conducta de la gente. }\end{array}$ \\
\hline
\end{tabular}




\begin{tabular}{|c|c|c|}
\hline CATEGORÍA & SUBCATEGORÍA & INDICADORES \\
\hline \multirow{4}{*}{$\begin{array}{l}\text { Continuación } \\
\text { Justificación en } \\
\text { asuntos de justicia } \\
\text { y orientaciones }\end{array}$} & \multirow{3}{*}{$\begin{array}{l}\text { Continuación } \\
\text { Juicios morales y } \\
\text { políticos }\end{array}$} & Justificaciones: orientación positiva \\
\hline & & $\begin{array}{l}\text { - Aplicación consistente, continua e im- } \\
\text { parcial de normas y reglas. } \\
\text { - Las normas morales han sido preesta- } \\
\text { blecidas por jueces. No son objeto de } \\
\text { un debate público. } \\
\text { - Las normas morales están orientadas al } \\
\text { castigo y la sanción. } \\
\text { - Los criterios de aplicación de las nor- } \\
\text { mas son estáticos e inmodificables. }\end{array}$ \\
\hline & & $\begin{array}{l}\text { Justificaciones deliberativas } \\
\text { - Los juicios morales y políticos presen- } \\
\text { tan los razonamientos políticos y mora- } \\
\text { les de los ciudadanos. } \\
\text { - Los juicios morales expresan razones } \\
\text { y se intercambian puntos de vista con } \\
\text { el propósito de llegar a un consenso o } \\
\text { definir un disenso. } \\
\text { - En asuntos morales y políticos, los su- } \\
\text { jetos tienen capacidad de descentra- } \\
\text { miento. } \\
\text { - La validez de las normas expresan los } \\
\text { principios de igualdad y equidad. }\end{array}$ \\
\hline & Justicia & $\begin{array}{l}\text { Concepciones de la justicia } \\
\text { - Los jóvenes se pliegan a los postulados } \\
\text { de una justicia formal. } \\
\text { - La justicia es distributiva, «a cada cual } \\
\text { lo mismo». } \\
\text { - El objetivo de la imposición de una san- } \\
\text { ción es generar «escarmiento». } \\
\text { - La justicia debe estar relacionada con } \\
\text { la consecución de derechos, libertades } \\
\text { y garantías constitucionales. } \\
\text { - Se debe aplicar la justicia de manera } \\
\text { imparcial. } \\
\text { - Hay que garantizar que las normas y re- } \\
\text { glas que no se ajustan a las condiciones } \\
\text { de la realidad o que pierdan su vigen- } \\
\text { cia, se cambien. }\end{array}$ \\
\hline
\end{tabular}




\begin{tabular}{|c|c|c|}
\hline CATEGORÍA & SUBCATEGORÍA & INDICADORES \\
\hline \multirow[t]{2}{*}{$\begin{array}{l}\text { Continuación } \\
\text { Justificación en } \\
\text { asuntos de justicia } \\
\text { y orientaciones }\end{array}$} & $\begin{array}{l}\text { Formas de } \\
\text { razonamiento }\end{array}$ & $\begin{array}{l}\text { Reconocimiento que estos tienen de } \\
\text { las normas y reglas motivados por: } \\
\text { - Obediencia o por expectativas exter- } \\
\text { nas. } \\
\text { - La actuación en la sociedad depende } \\
\text { del sistema de normas. } \\
\text { - Los principios morales guían la forma } \\
\text { de acción y de pensamiento moral. }\end{array}$ \\
\hline & $\begin{array}{l}\text { Pretensiones de } \\
\text { validez }\end{array}$ & $\begin{array}{l}\text { - La justificación de la justicia requiere } \\
\text { de una validez general para que al- } \\
\text { cance legitimidad. } \\
\text { - Se refieren a los sentimientos de apro- } \\
\text { bación o rechazo. } \\
\text { - formas de interacción de los ciudadanos } \\
\text { (estratégica, normativa o subjetiva). }\end{array}$ \\
\hline
\end{tabular}

\section{Algunos resultados en relación las Justificaciones en asuntos de justicia}

En las deliberaciones de ambos grupos de jóvenes participantes de este estudio, encontramos tanto los problemas de la sociedad colombiana (genocidios, masacres y barbaries) como sus posibles soluciones. En estas deliberaciones los jóvenes de ambos grupos presentaron a otros sus justificaciones porque consideraban que ellos razonablemente podían aprobarlos o argumentar sus desacuerdos. En otras palabras, los jóvenes de ambas poblaciones consideraron a sus interlocutores como válidos (Habermas, 1987).

Por lo tanto, resultó importante generar un ambiente comunicativo en el cual, mediante el uso de la razón pública, los jóvenes de ambos grupos pudieran dar a conocer sus deliberaciones en asuntos de justicia, con el objeto de presentar sus puntos de vista, conocer otros distintos a los suyos y llegar a algunos acuerdos libres de coacciones frente a temas en los cuales las opiniones eran divergentes, en especial porque sus experiencias morales los sitúan como testigos morales -en el caso de los jóvenes universitarios- o como víctimas morales -en el caso de los jóvenes desplazados- (Habermas, 1987).

La justicia se asumió como inseparable de procesos deliberativos, en los que se involucran todas las personas afectadas por decisiones morales y 
políticas. El carácter deliberativo, en asuntos de justicia, se entendió como un proceso comunicativo mediado por la realidad social, a partir del cual los jóvenes justificaron su concepción de justicia, exigieron las reivindicaciones de sus derechos y manifestaron sus aspiraciones emancipatorias y transformadoras.

El anterior marco de comprensión e interpretación permitió entender las concepciones acerca de la justicia de ambos grupos de jóvenes, en las que ellosexigieron, preferencialmente, una justicia formal, una justicia correctiva o paliativa y una justicia social, en las cuales la responsabilidad política, la imputación del daño moral y la sensibilidad moral se constituyeron en fundamento de explicación de la justicia.

Al respecto tenemos que las justificaciones acerca de la justicia proferidas por ambos grupos de jóvenes que guardan relación con los marcos de interpretación de la orientación deliberativa son:

En primer lugar, a nivel teórico, se consideró que los individuos, en todas las culturas, siempre tienen que dar razones para justificar una toma de decisiones en asuntos de justicia, lo que les permite, como miembros de la sociedad, asumir una perspectiva social. Por lo tanto, en esta investigación se consideró que las justificaciones acerca de la justicia están relacionadas con el mundo de la vida, con la existencia cotidiana y con los sistemas políticos reales (Habermas, 1998).

En términos empíricos se encontró que el mayor número de justificaciones, tanto de los jóvenes desplazados como de los jóvenes universitarios, están relacionadas con la toma de decisiones en situaciones de la vida cotidiana que tienen que ver con nuestro conflicto interno, en especial las relacionadas con el desplazamiento forzoso, la violación de los derechos y el desconocimiento de la dignidad humana expresada en la vulneración sistemática del derecho a la vida.

Otras justificaciones de los jóvenes desplazados y los jóvenes universitarios estaban relacionadas con la toma de decisiones en situaciones de la vida cotidiana referidas a los asuntos de la educación y de la familia, decisiones que deben estar orientadas bajo los criterios de responsabilidad moral y de cuidado por el otro.

En segundo lugar, así como en la orientación deliberativa la justicia tiene que ver con la capacidad de descentramiento del individuo, entendida 
como habilidad para ponerse en el lugar del otro y de generar, a partir de las declaraciones de otros, nuevos marcos de comprensión e interpretación del mundo social, encontramos que en las justificaciones en temas de justicia, tanto de los jóvenes desplazados como de los jóvenes universitarios, prevalecieron razonamientos morales y políticos relacionados con la responsabilidad por el daño moral causado por la violencia. En estos razonamientos, este daño moral no se asumió como un asunto que afecta a unos individuos, sino como un acontecimiento que causa "sufrimiento a todos los colombianos».

En la fundamentación de la orientación deliberativa y en las justificaciones de los jóvenes desplazados y los jóvenes universitarios, se encontró una perspectiva universal de la justicia regida por los principios de libertad, igualdad y equidad, en el sentido Kantiano. Por lo tanto, los asuntos relacionados con la justicia distributiva, para ambos grupos de jóvenes participantes de este estudio, tenían que ver con la organización de la comunidad de ciudadanos. Para los jóvenes, en sus justificaciones, la justa distribución de los beneficios sociales estaba relacionada con el carácter universal de la justicia, con su naturaleza normativa, y su propósito se orienta a garantizar la libertad e integridad de cada una de las personas como miembros de la sociedad.

En sus modos de razonamiento, los jóvenes desplazados y los jóvenes estudiantes emplearon tres tipos de justificación (pro-tanto, plena y pública) para señalar que la justicia se orienta bajo principios morales universales (Rawls, 1997). En la justificación pro-tanto encontramos una concepción política de la justicia, en la cual los jóvenes consideraron que las acciones justas se realizan en el marco de los principios morales establecidos en la Constitución y en las normas y las reglas previstas en los sistemas jurídicos. Por lo tanto, la justicia, para ambos grupos de jóvenes está relacionada con la Norma de las Normas (Constitución) y con el derecho. En la primera, para los jóvenes están fijados los principios, las instituciones y los procedimientos que son objeto de reconocimiento mutuo. Por su parte, los jóvenes consideraron que el derecho garantiza la interacción social y es el mecanismo social necesario para propiciar expectativas estables para la cooperación social (Habermas, 2004).

En la justificación plena, ambas poblaciones presentaron sus modos de razonamiento acerca de la justicia reconociéndose como miembros de una sociedad civil en la cual perviven distintas concepciones; no obstante, estos jóvenes admitieron que la estabilidad de la sociedad depende de la tole- 
rancia ante esta pluralidad de concepciones y de la aplicación consistente y permanente de las normas y las reglas. Finalmente, en la justificación pública, encontramos que las dos poblaciones defendieron su concepción política, orientados bajo criterios de equidad y considerando que la validez de sus justificaciones permitía alcanzar un consenso libre de coacciones.

En tercer lugar, se concluyó que, si bien los jóvenes presentan sus modos de razonamiento sobre la justicia reconociendo los principios morales y las normas jurídicas, encontramos que justamente la ausencia de estos principios y normas en situaciones de la vida cotidiana llevó a que los jóvenes denunciaran el grado de vulneración sistemática al que han sido sometidas las personas víctimas de la violencia. En consecuencia, los jóvenes exigieron acciones orientadas a corregir y a castigar a quienes han violado los derechos, con el fin de reparar por la vía jurídica el daño causado, por parte de quienes administran justicia.

Al lado de esta concepción de la justicia correctiva o paliativa, también se encontró que los jóvenes exigieron una justicia social en la cual se reconozcan sus derechos como miembros de la sociedad, y no se oculten los conflictos sociales y políticos por los que atraviesa nuestro país. En estas concepciones de la justicia (formal, correctiva y social), ambas poblaciones enunciaron comunicativamente el grado de importancia que tiene: a) la práctica discursiva en la comprensión y solución de conflictos; b) la sensibilidad moral en asuntos relacionados con la vulneración de derechos; c) la responsabilidad moral y política en temas de justicia relacionados con las personas y las instituciones valoradas como justas e injustas y la imputación del daño moral, en caso de violación de los derechos.

En cuarto lugar tenemos que, en coherencia con los marcos de la orientación deliberativa, en especial con Habermas, para ambos grupos de jóvenes la experiencia comunicativa permite conocer los juicios morales y la validez que tienen las normas consideradas dignas de reconocimiento (Habermas, 2004). Al respecto, tenemos que los jóvenes universitarios señalaban que los sujetos valorados como justos son, precisamente, aquellos que buscan entenderse con alguien y resolver los conflictos, para lo cual acuden a criterios racionales y comunicativos.

Por lo tanto, se encontró que ambos grupos de jóvenes reconocen la importancia de la práctica discursiva en la solución de los conflictos y la entienden como el mecanismo que hace posible, mediante juicios morales, 
conocer opiniones divergentes o saber cómo enfrentarse ante la extrema vulnerabilidad de las personas.

De acuerdo con el anterior hallazgo, tenemos que para Habermas (2004) la violencia comienza, precisamente, con la emisión de juicios orientados a manipular la comunicación, expresar intereses particulares y entablar una discusión bajo criterios de coacción. La violencia es una patología comunicativa que tiene como telos la destrucción de toda forma de acuerdo y de consenso a los cuales debemos aspirar en sociedades democráticas, mediante la racionalidad comunicativa (Habermas, 2004). Por su parte, los jóvenes desplazados consideran como injustas a aquellas personas que utilizan el lenguaje de la amenaza (acto de habla ejercitivo) con el objeto de ordenar su desplazamiento (efecto perlocutivo), o el "abandono de la tierrita».

En efecto, los jóvenes desplazados mostraron la fuerza ilocucionaria que tienen las órdenes, los imperativos y las amenazas en situaciones de conflicto. El lugar que ocupa -tal como se encontró- el acto ilocutivo en la violación de los derechos, coincide con el presupuesto de Habermas acerca de la violencia. Para este filósofo, la violencia comienza con la espiral de una comunicación deformada, en la cual se carece, entre otros, de tres mecanismos comunicativos orientados justamente al entendimiento en situaciones en las que prevalecen conflictos de intereses y opiniones divergentes.

Estos mecanismos comunicativos que a continuación se presentan, coincidieron con algunas justificaciones acerca de la justicia encontradas en ambas poblaciones. Estos son: racionalidad comunicativa, justicia y Constitución Política.

En la propuesta de Habermas, inicialmente encontramos la racionalidad comunicativa, la cual se constituye en un mecanismo que hace posible alcanzar el consenso entre participantes de una comunicación, que tienen perspectivas e intereses opuestos. El énfasis en la racionalidad comunicativa lleva a que sea la justicia el otro mecanismo que hace posible, por su carácter racional, que los ciudadanos puedan otorgar validez a las normas morales que gozan de reconocimiento intersubjetivo. Finalmente, la Constitución es otro mecanismo que permite a los ciudadanos reivindicar discursivamente sus derechos, porque en ella se fijan los procedimientos discursivos que deben operar en caso de conflictos. Los principios de libre expresión y de acción comunicativa previstos en la Constitución amparan, 
justamente, a los movimientos sociales que optan por la desobediencia civil como expresión de la resistencia (ver marco teórico).

En este estudio se encontró que la fuerza moral de los argumentos de los jóvenes universitarios se centró en la desobediencia civil, la cual se asumió como un derecho legítimo, ética y políticamente, al que tienen acceso como ciudadanos para derogar las normas jurídicas que representan intereses particulares, exigir la transformación y sustitución de aquellas normas que no representan los intereses de la comunidad y señalar los límites y las deficiencias con las que se adoptan algunas decisiones públicas en los sistemas democráticos.

Como quinta conclusión en esta investigación, tenemos el tema de la sensibilidad moral. Al respecto se encontró que, ante la vulneración de una norma o de un derecho, entran en juego los sentimientos de indignación, resentimiento, culpa y vergüenza. Estos sentimientos, que tienen su asiento en las experiencias del mundo de la vida cotidiana, tematizan, mediante juicios de valor, los asuntos relacionados con los conflictos, pero a su vez plantean soluciones posibles a los mismos (Habermas, 2002).

Los sentimientos morales tienen importancia para la justificación en asuntos de justicia porque permiten evidenciar las acciones injustas que vulneran el reconocimiento recíproco de los derechos. Asimismo, estos sentimientos morales, que tienen una estructura comunicativa, ponen de manifiesto que la indignación y el resentimiento aparecen como una afectación contra la «esperanza normativa» que goza de validez para los pertenecientes a un grupo social (Habermas, 1994).

Para los jóvenes participantes, en especial para los desplazados, la falta de reconocimiento de su estatus jurídico, los continuos agravios que reciben desde el momento en el que sufren «el síndrome de la amenaza», la desvalorización de sus modos de vida individual y colectiva, así como la negación de los aprendizajes morales adquiridos en las primeras etapas de su vida, están asociados con el sentimiento moral de indignación.

El anterior hallazgo coincide con el planteamiento de Rawls (1997), para quien la indignación moral es provocada por los daños y extorsiones que otros nos causan injustamente; indignación cuyo contenido moral responde a la trasgresión de las normas morales y sociales aprendidas en las diferentes asociaciones a las que el individuo pertenece (familia, escuela, vecindad, entre otros). 
Si bien el resentimiento fue la consecuencia del quebrantamiento sistemático de la dignidad humana, también expresó la invocación del derecho a la vida e indicó que la sensibilidad moral igualmente tiene un carácter racional, social y comunicativo, en tanto permite el reconocimiento del grado de injusticia de un agravio moral relacionado con asuntos de justicia y la emisión de un juicio moral sobre él.

En coherencia con los planteamientos de Rawls (1997), se encontró que los sentimientos morales de culpa y de vergüenza estaban más relacionados con la bondad que con la justicia. Así pues, la culpa indicó la afectación a los lazos de amistad, amor y confianza mutua establecidos en la esfera íntima (familia); por su parte, la vergüenza significó temor ante la burla, el desprecio y el escarnio.

El sentimiento moral de culpa expresado comunicativamente por los jóvenes desplazados, estaba relacionado con el amor que hacia ellos tienen sus familiares, quienes se desplazan, generalmente, para protegerlos. El sentimiento de vergüenza expresado por los jóvenes comunicativamente (actos de habla regulativos), se relaciona con la valoración negativa que de ellos tienen algunos miembros de la sociedad, aunque esta valoración se deba a situaciones que escapan al control de quien es valorado negativamente.

Como sexta conclusión tenemos que ambos grupos de jóvenes, en sus justificaciones relacionadas con la justicia social y con la justicia correctiva o paliativa, apelaron a la noción de responsabilidad y exigieron imputación del daño moral causado en situaciones de vulneración de derechos. De esta manera, la noción de responsabilidad se relacionó con la experiencia moral en asuntos de justicia porque, a partir de dicha noción, los jóvenes juzgaron y valoraron moralmente el sistema normativo que tejía su vida moral (Thiebaut, 2000).

En consecuencia se concluye que cuando ambos grupos de jóvenes justificaron la noción de responsabilidad en asuntos de justicia, estaban emitiendo juicios morales y atribuyendo con estos responsabilidades, no solo en relación con las acciones realizadas, sino con aquellas que se deberían realizar.

La atribución de la responsabilidad otorgada por los jóvenes difirió entre aquellas acciones relacionadas con los principios morales y las que están referidas al sistema jurídico y político. El primer tipo de responsabilidad se asoció, en ambos grupos de jóvenes, con la concepción de justicia basada 
en principios, mientras que el segundo tipo de responsabilidad, es decir la jurídica y política, tuvo que ver con la justicia correctiva o paliativa.

Al respecto, ambos grupos de jóvenes participantes de este estudio, en sus concepciones acerca de la justicia social, valoraron como justas tanto a la familia como a las instituciones de educación porque consideraron que en ellas prevalece un criterio de responsabilidad moral orientado al cuidado del otro y a la búsqueda del ejercicio de la ciudadanía.

Para los jóvenes, las acciones realizadas por los maestros ejemplifican la responsabilidad moral, no solo por las actuaciones pedagógicas de estos en campos disciplinares específicos, sino porque ellos son los «escultores»y «artífices» de la formación moral y ciudadana exigible a cualquier miembro de una sociedad, en especial en contextos de violencia como el nuestro: «el maestro ayuda a interpretar el problema de violencia y del conflicto en Colombia, para así poder salir adelante».

En las concepciones de los jóvenes universitarios acerca de la justicia correctiva o paliativa se encontró que, para ellos, la responsabilidad es de naturaleza jurídica y política, y surge del interés de enjuiciar negativamente y de exigir la sanción de aquellos hechos o acciones relacionadas con la violencia de nuestro país. Para los jóvenes universitarios, las acciones corectivas podrían resarcir por la vía jurídica el daño moral causado por la violencia y con ello propiciar un aprendizaje colectivo de naturaleza moral y ciudadana. Para estos jóvenes, exigir responsabilidad jurídica y política ante el daño moral implica rechazar públicamente los actos y las conductas que normativamente ellos consideran no justificadas porque violan las experiencias relacionadas con la justicia de las cuales depende, en buena medida, la vida moral.

En las justificaciones de los jóvenes en temas de justicia, tanto la responsabilidad jurídica como la responsabilidad moral estaban relacionadas con las formas de interacción y de convivencia en las cuales los jóvenes consideraron que los miembros de la sociedad se constituyen en sujetos morales y políticos. Asimismo, la responsabilidad se asumió por parte de los jóvenes desde su carácter relacional y de interacción con el otro en ámbitos normativos, lo que significó que estos atribuyeran responsabilidad a aquellas situaciones en las cuales se juzga jurídica y moralmente las experiencias de la vida moral y en las cuales también se otorga validez al sistema normativo. 
La séptima conclusión se relacionó con las orientaciones que subyacen en las concepciones de justicia. Al respecto, tenemos que en las justificaciones de los jóvenes desplazados y de los jóvenes universitarios en la justicia correctiva o paliativa apareció una orientación positivista, en la cual las acciones que no se ajustan a los criterios previamente establecidos en el sistema formal de la justicia deben ser objeto de sanción.

Aunque los jóvenes reclamaron la aplicación de normas jurídicas, a lo cual subyace una orientación positivista, también se encontró que, en un buen número de justificaciones relacionadas con la justicia social, predominó una orientación deliberativa. En esta orientación deliberativa ambas poblaciones exigieron el reconocimiento de sus derechos y de su dignidad humana, en especial en situaciones en las cuales predomina el horror de la violencia.

Asimismo encontramos en la concepción de justicia social, que los jóvenes recurrieron a una estructura comunicativa, relacional y tematizadora de la sensibilidad moral para justificar, mediante actos de habla, el grado de resentimiento e indignación que han sentido por la trasgresión de sus modos de vida y aprendizajes cívicos, promovidos por los miembros de las distintas instituciones en las cuales prevaleció el sentimiento de humanidad. En menor número, se encontró en la concepción de justicia formal una orientación intuicionista, en la cual predominó la idea de que las normas son buenas en sí mismas y que los individuos tienen un conocimiento intuitivo que los obliga a comportarse de forma correcta.

\subsubsection{Los límites del carácter deliberativo de las justificaciones morales en jóvenes universitarios y jóvenes desplazados en situaciones de conflicto interno: ética ante las víctimas}

Tal como se enunció en párrafos anteriores, otras justificaciones de los jóvenes acerca de la justicia relacionadas con nuestro conflicto interno, exigieron recurrir a un marco de interpretación no considerado en el capítulo de antecedentes y marco teórico de este estudio. Estas justificaciones, que están relacionadas con la noción de responsabilidad y con los sentimientos morales, nos llevaron a analizar el valor interpretativo que tiene, en situaciones de extrema vulneración de derechos, la ética ante las víctimas; perspectiva ética cuyos presupuestos cuestionan las teorías adoptadas en esta investigación. 
La ética ante las víctimas se entiende como la reflexión moral ante el tribunal de las víctimas de la violencia del hombre, es decir, ante situaciones de injusticia (Reyes, 2003). Al respecto, en las orientaciones analizadas en esta investigación, el tema de la justicia se centró en el estudio del lugar que ocupa el lenguaje moral, mientras que la ética ante las víctimas centra su interés en el ejercicio de la compasión para hacerse cargo y luchar a favor de la reparación de la injusticia.

La ética ante las víctimas exige una ampliación de la racionalidad propuesta en las teorías de la justicia cognitivas y procedimentales (RawlsHabermas) y propone el relato del testigo, no como simple justificación moral, sino como metáfora en la cual los derechos de las víctimas no han prescrito, por lo cual estas aún nos siguen interpelando a través del tiempo.

En esta ética ante las víctimas, en lugar de proponerse una justicia del deber en el sentido kantiano, según el cual el deber:

no descansa en sentimientos, impulsos e inclinaciones, sino sólo en la relación de los seres racionales entre sí, en la cual la voluntad de un ser racional debe considerarse siempre al mismo tiempo como legisladora, pues si no, no podría pensarse como fin en sí mismo (Kant, 1973, p. 92),

se propone una «ética del rostro», la que intenta expresar el imperativo del sufrimiento y exige el ejercicio de la compasión para hacerse cargo de los que no tienen voz (Levinas, 1991). Se trata de interpelar a la tradición moral, que pone su énfasis en la racionalidad y en la libre deliberación, con exclusión de los sentimientos y sin tener en cuenta, de manera explícita, aquellas situaciones en las cuales la debilidad de la víctima ante la violencia ejercida por el victimario, le impide constituirse en un interlocutor con capacidad argumentativa y, por tanto, le priva de su condición racional al negarle su condición de "fin en sí mismo» y convertirlo en un mero medio. Mirado de esta manera, podría decirse que el ejercicio de la compasión, como sentimiento frente al sufrimiento del otro y como reconocimiento de ese sufrimiento y de la negación que implica de ese otro como semejante, se constituye en un deber frente a la víctima. En este sentido, la ética ante las víctimas señala que la mirada de la víctima de la injusticia humana es inescapable.

En contraste con la ética del deber, en la cual las normas y las reglas requieren de una justificación para alcanzar su validez, en la ética ante 
las víctimas el deber se sustituye por el "acontecimiento ético», entendido como la existencia, en situaciones de sufrimiento, de la víctima y el verdugo. Por lo tanto, la justicia no es solamente un asunto de otorgar validez a las normas y las reglas, sino que implica también reconocer y hacerse responsable, como ciudadano, de la injusticia contra las víctimas, a quienes el miedo a la muerte violenta ha llevado a mirar el mundo desde la miseria (Benjamín, 1978).

De esta manera, mientras en las orientaciones señaladas en este estudio se recurre a una propuesta procedimental para dar cuenta de la justificación pública en asuntos de justicia (ética discursiva y posición original), en la ética ante las víctimas se recurre a las figuras del malestar, el dolor y el sufrimiento del inocente ocasionados, no por causas naturales, sino por la maldad del hombre. En las propuestas procedimentales se asume a los ciudadanos como participantes, libres de coacción, en situaciones de simetría, reciprocidad y mutuo reconocimiento, capaces de llegar al entendimiento mutuo. Por su parte, la ética ante las víctimas pone de presente que, en situaciones de extrema vulneración de la dignidad y de los derechos de las víctimas, las relaciones son asimétricas, manifiestan el menosprecio por el otro y, por tanto, hacen imposible el mutuo reconocimiento y niegan la posibilidad del entendimiento mutuo libre de coacción. La ética ante las víctimas propone una sensibilidad moral en la cual las exigencias de la justicia desborden la propuesta cognitiva y comunicativa de los sentimientos morales y acoge el sufrimiento humano como testimonio de lo que humanamente no debería suceder.

Por lo tanto para la ética ante las víctimas, en el discurso de la modernidad -en el cual se instalan las discusiones del giro lingüístico analizado en este estudio- la realidad de la justicia es de desigualdad. En tal sentido, esta perspectiva ética considera que hablar de igualdad es una trampa en la que se encuentra atrapada la modernidad; trampa que ha llevado a olvidar el deber de reconocer al pobre, a la viuda y al huérfano y el "hacerse cargo» de ellos (Reyes, 1997). La igualdad, tal como ha sido conceptualizada y llevada a la práctica por la modernidad, encuentra aquí una voz potente que la interpela y que le exige reconocer sus limitaciones históricas de facto. No debe perderse de vista, sin embargo, que esta interpelación a la igualdad, como de facto se ha dado históricamente, no puede hacerse sino desde la afirmación de la misma igualdad proclamada por la modernidad, no como la constatación de un hecho histórico, sino como una idea regulativa que constituye el horizonte que nos permite juzgar situaciones de extrema asimetría en las interacciones humanas y afirmar su injusticia y, por lo tanto, 
también exigir la reparación a la víctima (Vasco, Echavarría y Quintero, 2005, en prensa).

La justicia ante las víctimas, en oposición a las orientaciones adoptadas en este estudio, propone construir una teoría de la justicia que favorezca la mirada de la víctima, porque considera que las teorías modernas de la justicia privilegian el concepto de un sujeto moral abstracto y universal, que no padece las consecuencias de la injusticia. En consecuencia, la ética ante las víctimas toma como epicentro la justicia anamnética, la cual consiste en entender la memoria como la posibilidad de hacer justicia frente a la injusticia padecida por las víctimas de la violencia, hacer presentes las vidas frustradas y abrir los expedientes de los horrores de la violencia olvidados en la historia oficial (Reyes, 2003).

A partir de los anteriores postulados de la ética ante las víctimas, se propuso comprender algunas de las propuestas de ambos grupos de jóvenes, en las cuales encontramos el sentimiento de compasión y los ideales de justicia anamnética. En tal sentido, la compasión nutrió el recuerdo del sufrimiento y el reclamo por una justicia anamnética significó, justamente, apelar a la memoria y al olvido para denunciar la deuda ética contraída con las víctimas.

En efecto, ambos grupos de jóvenes, en temas relacionados con el dolor, el sufrimiento y la pérdida de humanidad en situaciones de conflicto, reclamaron una justicia en la cual se atribuyera responsabilidad al victimario que ha quebrantado una obligación moral, de manera que sea posible una sanción pública de carácter moral, es decir, que se lo obligue a asumir la responsabilidad ante el sufrimiento y el derramamiento de sangre.

No obstante, estos temas se convirtieron en conflicto moral para los jóvenes participantes cuando la idea de sanción o imputación del daño se acompañó de las propuestas de memoria, el perdón y el olvido de los crímenes de lesa humanidad. Al respecto, los jóvenes plantearon los interrogantes $i$ se hace justicia cuando se recuerda? y ise perdona al victimario o se perdona el acto cometido?

Si bien en ambos grupos de jóvenes los temas enunciados generaron conflicto moral, las justificaciones relacionadas con la memoria, el perdón y el olvido difirieron sustancialmente entre jóvenes desplazados y jóvenes estudiantes. Estas diferencias resultan principalmente del tipo de implicación que el joven tiene como víctima de la violencia, en el caso de los jóvenes 
desplazados, o como testigo moral de la misma, en el caso de los jóvenes universitarios.

Los jóvenes desplazados, en su condición de víctimas del conflicto, consideraron que si bien en su situación de desarraigo sus derechos fueron vulnerados, estos no han perdido su vigencia. En tal sentido, los jóvenes reclamaron una justicia en la que se reconociera la responsabilidad histórica que se tiene con los derechos de todos y cada uno de los miembros de la población desplazada, incluyendo sus muertos.

Los jóvenes entendieron esta responsabilidad histórica más allá del terreno jurídico, lo cual significó asumir la justicia como respuesta ante las experiencias de injusticia, en especial aquellas que produjeron el dolor y el sufrimiento de un inocente que «en realidad no sabe lo que está pasando y que sin más otros llegan y los matan sin corazón y los "degollan" sin mente...».

En esta responsabilidad histórica, los jóvenes desplazados consideraron que los acontecimientos de la violencia no pueden ser olvidados, porque la felicidad y el bienestar de ellos también dependen de que se reconozca públicamente que sus sufrimientos no son males naturales, sino producto de la injusticia del conflicto de un país en el cual ellos han sido las víctimas. No obstante, los jóvenes también señalaron que es necesaria la terapia del olvido para que los sueños de su juventud no sean perseguidos por los recuerdos de la violencia, aunque nada vuelva a ser como antes.

Generalmente, los jóvenes justificaron esta responsabilidad histórica, relacionada con la memoria, para reconocer el pasado y evitar que se repita la historia. Para los jóvenes desplazados hay, justamente, una deuda ética contraída con las víctimas que exige que las injusticias y las atrocidades de las masacres y las mutilaciones no queden archivadas y olvidadas, porque si esto sucediese, desaparecerían sus reclamos.

Por lo tanto, una política de memoria pública, tal como la exigieron los jóvenes desplazados, significa mantener vivas y vigentes las reivindicaciones de los derechos y de la búsqueda de dignidad que, en las historias de la violencia sufrida, les fueron pisoteadas o negadas por sus verdugos.

En este estudio se encontró que el olvido y la memoria no dejan abierta la puerta a la impunidad; tampoco se entendió el perdón a quienes cometieron los crímenes como pretexto para acallar las voces de los muertos, los 
desplazados, los desaparecidos y los secuestrados; el perdón, en este caso, se relacionó con la amnistía, con las acciones judiciales y con el derecho. Como bien lo señala Derrida (2003), aunque el perdón no hace justicia, ni sustituye a la justicia, no obstante los individuos, generalmente, asumen el perdón de manera condicional, tal como sucedió en esta investigación. Este perdón condicional pertenece a los órdenes del derecho, la política y la reconciliación, lo cual coincidió con las justificaciones de los jóvenes desplazados.

La memoria, el perdón y el olvido aparecieron, en esta investigación, a partir de las experiencias que causaron dolor, sufrimiento y pérdida de humanidad; experiencias que al ser tematizadas por los jóvenes, expresaron el sentimiento moral de compasión, que se produce como expresión de una experiencia de injusticia y miseria, y está asociado, entre otros, a la humillación y al menosprecio. La humillación es un tipo de dolor que afecta la identidad personal y que se convierte en indignación y/o resentimiento cuando se vuelve sistemático (Reyes, 1991). Por su parte el menosprecio, que también es un dolor, se asoció con la violencia simbólica en la cual el joven desplazado expresó el sentimiento de ser, sistemáticamente, desalojado del lugar simbólico que él suponía le correspondía ocupar por derecho (Arendt, 1987).

Para los jóvenes, el estatus jurídico de desplazado trae consigo incorporadas las experiencias de humillación y menosprecio. Humillación porque ser desplazado significó revelar que su dignidad humana fue vulnerada, con intención y en contra de su voluntad, por quienes sabían de antemano que estaban propiciando el horror de la violencia. Menosprecio en su condición de "buen ciudadano" porque en su experiencia de desplazado lo que se trasgredió, tal como se ha indicado anteriormente, fueron las normas morales y ciudadanas por ellos aprendidas y cultivadas con escrúpulo en las asociaciones a las que ellos pertenecían.

Por su parte, en sus justificaciones, los jóvenes universitarios, como testigos morales del conflicto interno colombiano, ubicaron la fuerza moral de sus argumentos en la búsqueda de una responsabilidad orientada hacia la imputación del daño moral ante estos hechos. Asimismo, estos jóvenes asumieron el dolor, el sufrimiento y la pérdida de humanidad centrados en el tema de las políticas del Estado en asuntos relacionados con el perdón y no en el sentimiento moral de compasión. 
La responsabilidad relacionada con una reflexión desde la imputación, tal como lo propusieron los jóvenes universitarios, implica reparar algo o hacer que el otro sufra por algo que ha cometido. Esta responsabilidad, contraria a la responsabilidad histórica, está asociada a la metáfora "dar cuenta», con la cual se quiere señalar el balance final (positivo o negativo), una vez realizada una acción (Reyes, 1997). Este tipo de responsabilidad se relaciona con la capacidad de juzgar una acción valorando para ello las consecuencias de los actos realizados a la luz de sus efectos (Thiebaut, 1997).

En su condición de testigos morales y no de víctimas, el tema de la responsabilidad llevó a que los jóvenes universitarios plantearan juicios morales relacionados con el significado que tiene el perdón cuando no se es víctima del conflicto y cuando el perdón es exigido mediante una imposición legal.

Para Derrida (2003), precisamente, la contradicción entre una propuesta del perdón condicional frente a una propuesta del perdón incondicional radica en que en el primer tipo de perdón la relación es entre el culpable, la víctima y un tercero, en nuestro caso, la política del Estado (Ley de Justicia y Paz). Esta relación prevalece en las propuestas de los Estados que buscan amnistía o negociaciones pragmáticas. En el segundo tipo de perdón, es decir el incondicional, el perdón se asume como la tarea imposible de perdonar lo imperdonable. Esto explica por qué el perdón no se puede reducir a perdonar en nombre de las víctimas, porque pierde toda su legitimidad moral (Derrida, 2001).

Algunos interrogantes que los jóvenes universitarios plantearon frente al tema del perdón fueron: ¿a quién perdonar?, ¿qué perdonar? y ¿quién perdona? Estos interrogantes surgieron cuando en las entrevistas apareció el tema de una política del perdón y fueron estos, justamente, los que generaron conflicto moral porque sus respuestas, consideraron lo jóvenes, no podrían ser las mismas cuando el que perdona toma la decisión ubicándose en una situación hipotética (juez), como cuando el que perdona es aquel que está en condición de víctima, como es el caso de los desplazados.

Finalmente, se propone la siguiente reflexión, la cual permite orientar otras investigaciones interesadas en el tema de la justicia: las evidencias teóricas y empíricas en este estudio señalan que en las concepciones de los jóvenes convergen los ideales de una justicia universal, cognitiva y simétrica con los presupuestos de una justicia en la cual el reconocimiento del dolor y del sufrimiento de las víctimas tiene valor moral. En estos dos presupuestos acerca de la justicia, aunque conceptualmente se encuentren 
en tensión, pervive la sentencia de Kant (1989): «Si la justicia perece, no le merece a los hombres vivir sobre la tierra».

\subsection{Los sentimientos morales y políticos en el ejercicio ciudadano: ¿un asunto de formación ${ }^{5}$}

Aunque en Colombia, a partir de 1994 encontramos un importante cúmulo de iniciativas acerca de la formación ciudadana, sus antecedentes datan de 1820 con la propuesta de formación popular. Posterior a esta, encontramos que las iniciativas de formación se centraron en moral, virtud y urbanidad (1865); seguidamente, tenemos los asuntos relacionados con instrucción cívica (1910) y con el catecismo del ciudadano (1926). Más recientemente, encontramos la propuesta de competencias ciudadanas (2003).

A partir de estas iniciativas podemos señalar que existe una cartografía de la formación ciudadana en la que prevalecen: a) unas coordenadas espaciotemporales que dan cuenta de las prácticas éticas y políticas y, con ello, de los modos de subjetivación y socialización política; b) un aparato de enunciación legislativa que señala los modos de construcción de la subjetividad moral y política de niños, niñas y jóvenes; y c) unas técnicas y métodos de enunciación acerca de la formación ciudadana expresados en manuales, cartillas, cuentos, guías, entre otros.

En esta cartografía surgen algunos interrogantes: ¿realmente se nos enseña a ser ciudadanos?, ¿cuáles son los objetos de enseñanza de la formación ciudadana?, ¿la formación ciudadana es un asunto más ligado a la praxis que a procesos de enseñanza?, ¿dónde se nos enseña a ser ciudadanos?, ¿esta

5 Las reflexiones y resultados que se presentan en este acápite hacen parte de la investigación Cartografías de la formación ciudadana en Colombia: Texturas de los sentimientos morales y políticos en la construcción del otro-vivir juntos. Esta investigación se estructuró en 3 fases. La primera se centró en la búsqueda de información secundaria en archivos de 1800 relacionados con la formación ciudadana. Se acompañó este trabajo de recolección de información con la construcción de un corpus empírico y conceptual acerca de los atributos y estigmas en la formación ciudadana. El objeto principal fue indagar acerca del lugar que tienen las emociones en la formación ciudadana. Estos resultados se presentan en este libro. La segunda fase, en proceso de ejecución, sin perder como objeto de estudio las emociones, busca determinar los modos de reconocimiento y menosprecio hacia el otro, nuestros congéneres, es decir, hacia la vida ciudadana. En esta segunda fase se continúa con el trabajo de archivo, pero se amplía hacia el periodo de 1950. La tercera y última fase busca profundizar el trabajo de archivo hasta nuestros días. El objetivo central de las 3 fases es comprender cómo desde las emociones hemos construido en procesos formativos la imagen y la praxis moral y política con el otro; en otras palabras, se trata de dar cuenta de la alteridad como aspecto central en la ciudadanía. Proyecto realizado por Marieta Quintero (2013-actualmente). 
formación es un asunto restringido a los contextos educativo y familiar? y si es así, ¿qué lugar tienen en esta formación otros ambientes democráticos distintos a la familia y la escuela, como el barrio, la vereda, departamento, e incluso el país en el cual se despliegan las prácticas de los ciudadanos?

Aunque para algunos(as) la ciudadanía no es objeto de formación, e incluso se reduce a la participación electoral, planteamos que existe una formación ciudadana ligada tanto a la praxis como a los conocimientos que se despliegan en contextos educativos, sociales y culturales. En tal sentido, esta noción de formación se refiere a los aspectos relacionados con la cultura y la humanidad. Esta formación, que no se restringe al cultivo de las capacidades y talentos, también se refiere a la sensibilidad moral y política. Por ello en esta cartografía consideramos que la formación ciudadana tiene un vínculo estrecho con el ejercicio ciudadano, ya que esta praxis no está desprovista de los siguientes aspectos: saberes, conocimientos y sentimientos.

De los aspectos enunciados, en esta investigación nos centramos en los atributos de los sentimientos en procesos de formación. Al lado de estos atributos se analizan algunos estigmas que han llevado a considerar que estos no deben hacer parte de los procesos de formación. Partimos de la tesis que los sentimientos son piedra angular en la formación ciudadana.

Tanto los atributos como los estigmas se analizarán a la luz de las teorías de la moral y la política, mientras los asociados a situaciones de orden social, cultural y educativo serán interpretados a partir de fuentes de información secundaria, en particular con archivos relacionados con la formación ciudadana que datan de los periodos de 1800 y principios de $1900^{6}$. El presente periodo se analizará a la luz de los hallazgos obtenidos en un estudio investigativo financiado por el ICFES, COLCIENCIAS, la Universidad Distrital y CINDE. En este se buscó conocer los procesos de formación ciudadana de niños, niñas y jóvenes en contextos escolares afectados por el conflicto interno colombiano.

6 Para este informe se recogen los hallazgos del proyecto de investigación Programas de formación y evaluación de competencias ciudadanas en zonas de conflicto interno colombiano: análisis de impacto en los aprendizajes ciudadanos, financiado por el ICFES y COLCIENCIAS. Este proyecto fue ejecutado por la Universidad Distrital Francisco José de Caldas y CINDE e identificado con código 113051828140. 


\subsubsection{Acerca de los sentimientos en la ciudadanía ${ }^{7}$}

Uno de los aportes de este estudio fue brindar un corpus conceptual acerca de los sentimientos. Al respecto se encontró que en las tradiciones cívicas (liberalismo, comunitarismo y republicanismo), los sentimientos son objeto de estudio por un número reducido de teóricos; entre otros, tenemos a Hutcheson (1999), Hume (1989; 1990; 1992; 2006), Smith (1996), Strawmson (1995), Heller (2004), Nussbaum (1995; 1997; 2003; 2006; 2008) y Honneth $(1997 ; 2009 ; 2010 ; 2011)$. Mientras que en el campo de la formación ciudadana, encontramos una mínima fundamentación, por no decir nula. Es preciso señalar que en esta formación prevalecen asuntos relacionados con:

- Conocimientos: ¿qué debo saber o conocer?

- Acciones: ¿qué decisiones debo tomar? y ¿qué debo hacer?

- Actitudes: ¿qué esperamos que un sujeto haga en ciertas actuaciones? y ¿cuáles son las disposiciones que tenemos para hacer cierta clase de juicios o para actuar de cierta manera?

También ha predominado el carácter cognitivo de la moral, donde se considera que existe una interacción entre las estructuras propias de los sujetos (cognitivas) con las del medio social. Esto ha llevado a que la formación se centre en el desarrollo de los juicios, los cuales contienen los criterios de racionalidad requeridos para el ejercicio ciudadano. Estos juicios son considerados más complejos cuando los sujetos tienen mayor capacidad comprensiva, interpretativa y explicativa de los fenómenos a los que se enfrenta en la vida cotidiana (Habermas, 1994; Kohlberg, 1992 y Rawls, 1995). En particular estos juicios se refieren a la justicia, por ser considerada criterio y fundamento de la dignidad humana y de la condición ciudadana.

Lo anterior explica las razones de orden conceptual y empírico que han llevado a que en procesos de formación ciudadana exista privilegio por la vía cognitiva de la justicia, y menos por su comprensión en contextos sociales o en relación con la vulneración de derechos. Este posicionamiento cognitivo de la justicia en asuntos de ciudadanía tiene su génesis en la tradición de la filosofía moral griega (Aristóteles y Platón), sus más elaborados fundamentos en la tradición moderna (Kant y Rousseau) y sus más destacadas evidencias empíricas en el mundo contemporáneo (Piaget y Kohlberg).

$7 \quad$ Algunos de los aspectos teóricos y empíricos del presente apartado están publicados en el artículo: «Sentimientos morales y políticos en la formación ciudadana: atributos y estigmas», en la Revista Folios, de la Universidad Pedagógica, 2014. Artículo elaborado con Jennifer Mateus Malaver. 
Entre otros atributos, tenemos que los sentimientos permiten que la vida moral no se restrinja al plano individual, pues estos están relacionados al carácter intersubjetivo. Adicionalmente están vinculados con los derechos, es decir, con la vida política. Los sentimientos de entusiasmo o de censura, positivos o negativos, en relación con los demás, tal como lo señala Hoyos, G. (2004), motivan acciones individuales y colectivas orientadas a demandar imputación, resistencia y desobediencia civil ante situaciones de injusticia.

Los sentimientos son fuente de comprensión de las ambivalencias y de los marcos de acción que motivan o restringen la vida digna y buena, así como el buen vivir. Por ello, operan como filtros y «termómetros» morales y políticos de lo que acontece en nuestras experiencias en la sociedad y en nuestros círculos más cercanos.

Los anteriores atributos son resultado, entre otros, de dos aspectos. Por un lado, estos contienen las creencias y valoraciones de los ciudadanos acerca de la vida con los otros, las cuales se adquieren en los procesos de socialización y subjetivación, así como en los ambientes de aprendizaje. Del otro, los sentimientos son de carácter cognitivo, comunicativo e intersubjetivo. Por ello orientan y guían las acciones, la toma de decisiones y la manera como nos vinculamos con los otros.

En cuanto a los estigmas tenemos:

- Estigmas filosóficos. Los sentimientos morales son fuente de confrontación y de discordia porque ellos encarnan ausencia de reflexión y de capacidad racional.

- Estigmas de orden sociocultural y educativo. En la constitución de las identidades, el dominio de los sentimientos es propio del sujeto racional y civilizado. El gobierno de las emociones indica superación de la condición del sujeto bárbaro, salvaje e incivilizado; nominaciones presentes en la cartografía de la formación ciudadana.

A partir de lo expuesto se plantean tres tesis. En la primera se sostiene que los estigmas enunciados han dado lugar al control de cualquier expresión de sentimientos en procesos de formación ciudadanía. En la segunda, se señala que cuando aparecen los sentimientos estos se orientan, de un lado, a promover la obediencia y subordinación, y del otro, a fortalecer sentimientos negativos - repugnancia, odio, asco, entre otros- asociados a la urbanidad, higiene y a los buenos comportamientos. Finalmente se sostiene 
que, en buena medida, en procesos de formación en ciudadanía, los sentimientos juegan un papel central.

\subsubsection{Atributos de los sentimientos morales y políticos}

Los fundamentos de las éticas basadas en los sentimientos morales, en buena medida, se oponen a las tesis de las éticas racionalistas. La reacción más fuerte está presente en Hume, quien en 1751 sostiene que los sentimientos motivan la vida moral y no la razón. Por ello, la toma de decisiones y la realización de acciones morales expresan el placer y la alegría que nos proporciona la búsqueda de la felicidad de la humanidad. Podríamos decir, entonces, que las acciones morales no dependen de la razón, sino de los deseos, pasiones y afectos de los seres humanos. Esto no significa que no podamos razonar acerca de las pasiones. En tal sentido, indica Hume (2000) que la razón es una esclava de las pasiones y no puede pretender otro oficio distinto que ser surbordinada a estas.

Sin embargo, no podemos limitar la arquitectura filosófica de las emociones a las tensiones entre razón y emoción, aunque estas discusiones han dado lugar a las más fructíferas aclaraciones sobre los atributos de los sentimientos. En su lugar, destacamos la riqueza en los argumentos acerca del carácter intersubjetivo y relacional presente en los sentimientos morales. Esto significa que los ciudadanos adquirimos un sentido de lo público cuando rechazamos todas aquellas acciones egoístas que conducen a la miseria y sentimos felicidad por aquellas acciones que propician un mayor bien. El interés por el bien común significa búsqueda de la realización de la comunidad moral.

Para alcanzar este bien común, las éticas de los sentimientos morales propusieron, en sus inicios, los sentimientos de benevolencia y simpatía. Precisamente el filósofo Hutcheson (1725), considerado el primer exponente de la teoría de los sentimientos morales, propuso la benevolencia como el sentimiento a través del cual el sujeto expresa y actúa para alcanzar el bien público. Dicho sentimiento por su interés social exige, siguiendo al autor, poner al margen cualquier inclinación personal.

Los presupuestos de Hutcheson fueron retomados por el filósofo Hume, quien consideró que el sentimiento de benevolencia tiene como mérito estimular a la especie y otorgar felicidad a la sociedad humana: «La felicidad 
de los hombres, el orden de la sociedad, la armonía de la familia, la ayuda mutua de los amigos son siempre considerados como resultado de su benévolo dominio en el corazón de los hombres» (Hume, 2003, p. 43).

Para Hume, la naturaleza humana nos hace seres sociables, compasivos y amables; características que están presentes en el sentimiento más elevado: la benevolencia. Sin embargo, la inclinación natural benevolente en todos los seres humanos nos convoca a la simpatía. Este sentimiento es, quizás, siguiendo al autor, una de las características esenciales de la naturaleza social de los individuos. Por ello, el autor sostiene que el hombre vive en círculos que se van ensanchando gracias al sentimiento de simpatía. Las acciones humanitarias y las realizadas en el marco de la amistad, gratitud y generosidad son expresiones de la simpatía que tenemos por nuestros congéneres y nuestra especie.

En consecuencia, Hutcheson y Hume consideraron que el ser humano no es capaz de profesar una maldad, pues no existe en su naturaleza humana ninguna condición que lo lleve a desear la miseria ajena. Sin embargo, Hume reconoce que en todo sistema social existen dificultades que deben solucionarse para propender por el bien de la sociedad en su conjunto. Esto llevó a que propusiera al lado de las virtudes naturales (benevolencia y simpatía), la virtud artificial de la justicia. En consecuencia, la justicia es un artificio que permite solucionar las dificultades que se padecen en cualquier orden social.

Influenciado por el pensamiento de Hume, el pensador Smith -en su trabajo sobre la teoría de los sentimientos morales (1997)- retoma la simpatía como el sentimiento que lleva a los individuos a interesarse por la suerte de los otros. Pero también a sentir compasión ante la desgracia ajena. Para Smith, sentir pena por las penas de otros no requiere demostración alguna. También sostiene que ni el mayor malhechor, ni el más brutal violador de las leyes de la sociedad, carecen del sentimiento de la simpatía (1997).

Uno de los rasgos de la simpatía es depender de la imaginación del espectador. Siguiendo al filósofo, dicha imaginación significa capacidad para involucrarse en una situación que provoque vivacidad u opacidad. En otras palabras, tener la capacidad de imaginar de manera que se apruebe o repruebe lo que acontece en la esfera de las relaciones sociales. Esta imaginación permite ponernos en la situación de los otros y concebirnos a nosotros mismos como soportando los mismos tormentos. 
Asimismo la imaginación, que opera como facultad, permite formar creencias, valoraciones y juicios morales. En esta propuesta quien imagina es considerado el espectador y a quien se dirigen los sentimientos de simpatía y benevolencia es Ilamado el protagonista o persona moral. La relación entre estos dos actores -espectador y protagonista- emerge en situaciones o circunstancias de fragilidad y contingencia presentes en la esfera social. Por lo tanto, los vínculos que dan lugar a la imaginación moral no resultan de una simple observación, provienen de la experiencia; vínculos que permiten a los sujetos ser conscientes de su propia debilidad, así como reconocer la importancia que tiene la presencia de los otros en su propia vida.

Esta imaginación opera de la misma manera que en las éticas racionalistas como aquella capacidad o facultad que tiene el sujeto de ponerse en el lugar de los otros y sentir compasión. Sin embargo, a diferencia de estas propuestas morales de naturaleza racional, para Smith, siguiendo a Nussbaum (1997), las emociones no solo se basan en las creencias y razonamientos, sino también resultan de su vívida imaginación:

la posición de Smith (y la mía) es que están implícitas en ciertos pensamientos que es apropiado poseer acerca de lo que sucede a la persona que está delante de nosotros; más aún, forman parte del equipo con que registramos lo que sucede. Las reacciones del espectador no son meras actitudes voluntarias de preocupación, sino emociones, y, evidentemente, Smith cree que el cultivo de las emociones apropiadas son útiles para mostrarnos lo que podría hacer, y además poseen su valor moral, como reconocimientos del carácter de la situación que enfrentamos (Nussbaum, 1997, p. 109).

Para Smith la simpatía posee un carácter relacional y expone la naturaleza necesitada de los seres humanos. El primero de estos aspectos (carácter relacional) significa que el sujeto siente regocijo cuando advierte que sus conciudadanos gozan de sus pasiones y se afligen por sus dolencias. En otras palabras, la simpatía tiene un carácter recíproco, pues aviva la pasión cuando sentimos felicidad por los placeres y consternación por los sufrimientos de los otros.

El segundo aspecto relacionado con la naturaleza necesitada de los seres humanos, indica que estos buscan la simpatía de los demás porque necesitan de su cuidado y amor. Asimismo, el carácter necesitado muestra el peso que tiene la experiencia en el campo de la moral, pues conocemos la bondad, el amor y el interés público cuando nos relacionamos con los otros. Podemos sostener, entonces, que la naturaleza necesitada es expre- 
sión de nuestra sociabilidad, en la cual las acciones, decisiones, modos de organización, distribución del conocimiento y de las estructuras de poder, entre otros, sirven al ciudadano como espejo emocional:

Al entrar en la sociedad, inmediatamente es provisto del espejo que antes le faltaba. Está desplegado en el semblante y la actitud de las personas que lo rodean, que siempre señalan cuándo comprenden o rechazan sus sentimientos, allí es donde contemplan por primera vez la propiedad o impropiedad de sus propias pasiones, la hermosura o fealdad de su mente (Smith, 1997, p. 228).

Los anteriores itinerarios nos sirven para situar los atributos de los sentimientos en la ciudadanía, es decir, las actitudes y acciones que adoptamos y esperamos que adopten nuestros iguales frente a determinadas situaciones en la vida humana. En otras palabras, las preferencias, reprobaciones o la misma indiferencia de nuestros congéneres frente a los infortunios o situaciones de vulneración de derechos que erosionan o exaltan nuestros sentimientos. La vergüenza e indignación son sentimientos estrechamente relacionados con situaciones de vulnerabilidad en las que reconocemos los perjuicios vividos y en las que nos sentimos afligidos por la suerte acaecida (propia o ajena) Estas emociones nos recuerdan por qué se hacen necesarias las leyes, siguiendo a Nussbaum (2006). También muestran las razones por las cuales los seres humanos somos seres frágiles y, por ello, tememos a los infortunios que puedan sucedernos. Como señala Rousseau, citado por Nussbaum, «nuestra inseguridad es inseparable de nuestra sociabilidad y de nuestra propensión a nuestro vínculos emocionales» (Nussbaum, 2006, p. 20).

Lo expuesto indica, en primer lugar, que existen sentimientos reactivos o negativos -vergüenza e indignación- vinculados a experiencias de vulneración, los cuales ocupan un lugar ponderante en el campo del derecho. La noción «negativo» no ha de entenderse como detenernos o «paralizarnos» ante la ejecución de acciones jurídicas. Son sentimientos negativos en tanto expresan violaciones que requieren, justamente, de la existencia de normas y leyes jurídicas que hagan posible la reparación y restauración del daño causado.

Por ello, los sentimientos reactivos son un indicio o señal del estado de criminalidad de un país y expresión del grado de estabilidad y cohesión de la democracia. A manera de ilustración, en Colombia, en narraciones de jóvenes víctimas de la violencia, la gramática de los sentimientos morales nos muestra la vergüenza que significa para un joven que ha sido víctima 
del conflicto, relacionarse con los otros bajo la denominación «soy desplazado», ya que significa ser hijo de la violencia y la miseria y, por lo tanto, objeto de menosprecio y humillación. Asimismo, la anterior denominación se asocia al sentimiento de indignación porque sus aprendizajes adquiridos en contextos rurales se convierten en objetos de burla y ausencia de benevolencia a pesar de que su único infortunio es vivir en zonas de conflicto armado. Tanto la vergüenza como la indignación son señal de experiencias sufridas, de menosprecio en condición de indefensión, pero también, expresión de la búsqueda de imputación ante la justicia por los daños ocasionados -emociones y derecho-.

Los sentimientos de vergüenza e indignación en el derecho son motores, entre otros, de dos acciones políticas complementarias. Por un lado, dan a lugar a luchas sociales, a la resistencia y desobediencia civil ante situaciones de injusticia. Del otro, justifican las normas legales en tanto invocan sanciones penales, pero así mismo, restauración de daños y perjuicios. Esta justificación también muestra la importancia de la justicia dinámica (Heller, 1998) en tanto sitúa las normas y reglas en coherencia con los contextos sociales y políticos. En consecuencia, las relaciones entre los grupos y las dinámicas de las sociedades exigen cumplimiento de las normas, pero también modificación y apertura de otras que hagan posible el bien común. También es dinámica porque las normas y las leyes con el tiempo: a) pierden cualidades; b) carecen de validez; c) su observancia y experiencia contradice lo que indica la norma, en otras palabras, no representan un modo de vida buena, justa o del buen vivir (Heller, 1998). Esta gramática de los sentimientos, nuevamente, ilustra los vínculos entre emociones y derecho.

En segundo lugar, estos sentimientos reactivos nos recuerdan nuestra condición de seres frágiles y necesitados. Los sentimientos morales de indignación, vergüenza, culpa, repugnancia, entre otros, son respuesta al grado de vulnerabilidad al que podemos estar expuestos. Siguiendo a Rousseau, citado por Nussbaum (2006), el sentirnos frágiles o reconocer que no somos dioses hace posible que entendamos los vínculos que nos unen con los otros. Carecer de esta noción de fragilidad o de poder estar expuesto a situaciones de contingencia nos Ileva a tener un grado de autosuficiencia y a sentirnos inmunes, lo que puede llevar a que «extirpemos» todas aquellas emociones vinculantes. También, esta ausencia de sabiduría práctica puede llevar a que los ciudadanos le den la espalda a cualquier tipo de experiencia en la cual aparezca la indefensión e, incluso, a que consideren que los conflictos no hacen parte de su vida, pues son desastres extraordinarios a los cuales no estarán expuestos, ni dispuestos a sensibilizarse. Esto lleva a 
que el ciudadano no actúe ni exija derechos ante los infortunios vividos en la vida pública -indiferencia moral y política-.

\subsubsection{Estigmas acerca de los sentimientos morales en la formación ciudadana}

Para desarrollar este acápite primero presentaremos los estigmas de orden filosófico y posteriormente los relacionados con lo educativo, centrados en la cartografía de la formación ciudadana en Colombia.

Estigmas filosóficos y sociales. Uno de los estigmas que se busca rebatir es la opinión generalizada de que los sentimientos no son fuente adecuada para la toma de decisiones por su carácter de irracionalidad. Para ello se retoman las objeciones planteadas por Nussbaum (1997). Inicialmente, la autora indica que las emociones hacen parte de las "experiencias humanas», las cuales involucran creencias hasta el punto de que el mismo Aristóteles, en la Retórica, da consejos a jóvenes oradores acerca de cómo crear emociones en sus auditorios. Si la Retórica -que estudia y utiliza el lenguaje a partir de un sistema de reglas y de una estructura lógica y argumentativa- crea emociones en el auditorio, podemos afirmar que estas no son irracionales. Este atributo permite sostener, siguiendo a Nussbaum (2006), que las creencias son bases esenciales en la emoción. Entre los ejemplos propuestos por la autora, tenemos que si un orador quiere generar temor debe convencer al auditorio de que ocurrirán cosas malas y que no se pueden impedir tales sucesos. Asimismo, si busca generar enojo, debe convencerlos de que han ocasionado un perjuicio de forma voluntaria e injusta.

Otro argumento que ilustra el por qué las emociones contienen creencias, reside en la capacidad que tenemos para definirlas y emitir juicios alrededor de estas. Por ejemplo, para definir sentimientos reactivos o negativos -temor y pena- necesitamos incorporar las creencias que tenemos acerca de estos, de lo contrario no podríamos identificarlos como negativos, es decir, estarían desprovistos de la noción del daño causado: «El temor, por ejemplo, involucra la creencia de que algo malo ocurra en el futuro. La ira, la creencia de un daño infringido injustamente. La pena requiere la creencia en el sufrimiento significativo de otra persona»(Nussbaum, 2066, pp. 41-42).

Para Nussbaum, otro argumento frecuentemente generalizado, es que los sentimientos son propios de la estructura femenina, mientras que la razón 
es rasgo característico de los hombres. A juicio de la filósofa Guerra (2011), los sentimientos morales, más que otros temas, poseen connotaciones sexistas. Indica la autora que desde los estoicos hasta Kant, se ha considerado que los sentimientos que oscurecen, distorsionan y arruinan el juicio son propios de la vida de las mujeres. Por ello, a las mujeres se les ha imputado inferioridad racional -Kant, Piaget y Kohlberg-. Llama la atención que los atributos de estos sentimientos relacionados con el afecto, lo maternal, filial, conyugal y comunitario en asuntos de ciudadanía estén arrojados en la esfera de la irracionalidad, cuando son la base para la acción y la decisión de los ciudadanos.

Otra objeción planteada por Nussbaum se relaciona con la idea generalizada de que los sentimientos se restringen a los lazos o apegos cercanos al yo. Se sostiene que las emociones son propias de los círculos éticos próximos: «Las emociones siempre permanecen cerca del hogar y contienen, por así decirlo, una referencia de primera persona» (Nussbaum, 2006, p. 92). Esta cita nos ilustra porque los sentimientos han sido considerados por filósofos y ciudadanos como fuerzas ciegas que no guardan relación con círculos éticos amplios y, por lo tanto, carecen de cualquier valor político.

Una consecuencia de lo expuesto es suprimir o excluir las emociones de la vida pública y arrojarlas a la esfera de lo íntimo. En oposición a este argumento, Nussbaum señala que las emociones son intencionales, por lo tanto somos capaces de identificarlas y asociarlas a contextos y situaciones, independiente de que estas se desplieguen en las esferas de lo privado o lo público. De lo contrario, careceríamos de capacidad para identificar que las emociones que se presentan en las distintas esferas comunican y expresan las intencionalidades que tienen los ciudadanos en sus marcos de acción individual y colectiva, las cuales pueden estar orientadas al reconocimiento y respeto de los derechos, a la indiferencia o a la vulneración de los mismos.

\subsubsection{Estigmas en la formación ciudadana: textos escolares}

A partir de lo expuesto analizaremos cómo en procesos de formación ciudadana en Colombia, las emociones han sido tratadas con los mismos estigmas que señala Nussbaum en su obra. Las consecuencias de este tratamiento no solo son de orden filosófico y educativo, sino que develan y explican algunos prejuicios y estereotipos presentes en nuestros modos de relacionarnos en la vida moral y política. En especial, permiten com- 
prender por qué nuestras creencias, actitudes y prácticas ciudadanas han estado, históricamente, formadas para «despojar» las emociones. Asimismo, esta trayectoria permite conocer aquellos momentos y coyunturas de nuestra formación ciudadana en las que se promovieron emociones ligadas a lo ético y lo político, pero que por situaciones de poder -Corona Española- quedaron menguadas y cooptadas, hasta llegar a distorsionarse sus atributos.

Estas prácticas formativas igualmente develan y hacen posible comprender las situaciones de indiferencia, burla, insolidaridad, pero también la resistencia y rebeldía, entre otros, presentes en la vida política y moral, en especial en épocas afectadas por la subordinación española, la Violencia y, más recientemente, por el conflicto armado. En estos fenómenos las emociones juegan un papel fundamental, pues elevan el sufrimiento, la indignación y resentimiento al estatus del derecho. En otras palabras, los daños morales y políticos demandan imputación, resistencia y desobedecía civil.

\subsubsection{Acerca de la formación ciudadana y los sentimientos en Colombia}

La cartografía de la formación ciudadana la situamos en 1814, periodo en el cual encontramos el Catecismo o instrucción popular, escrito por Juan Fernández de Sotomayor, quien además de redactar esta obra, funge como cura, rector, vicario y juez eclesiástico de la ciudad de Mompox. El pensamiento y obra de Fernández de Sotomayor fue considerado revolucionario porque refutó las estructuras de poder de la Corona española, incentivando los sentimientos de indignación y resentimiento como expresiones de resistencia y rebelión, es decir, como emancipación.

El método o técnica pedagógica que utilizó fue el Ilamado "catecístico», el cual consistió en exponer de forma sencilla y breve los fundamentos, ideas o saberes en un tema. Para desarrollar los contenidos y favorecer la memorización de los alumnos, empleó como estrategia didáctica la pregunta y respuesta. La tipología discursiva predominante fue la expositiva, precisamente porque permitía la concisión en el discurso, el empleo de expresiones técnicas y el uso de la tercera persona.

Este método de instrucción popular, por su sencillez y por las prácticas precisas que en ellas se promovían, ha sido considerado uno de los primeros textos escolares. Su trayectoria formativa se vincula con la evangeliza- 
ción de los españoles en América, sin embargo, a partir de 1810 aparecen los catecismos políticos cuyos contenidos fueron la Constitución, lo patriótico, las obligaciones civiles y morales; algunos de estos catecismos fueron censurados por la Corona Española porque se alejaban de los objetivos de respeto y obediencia a Dios y al Poder político. En su lugar, promovían la independencia y los conceptos de libertad y derechos (Ocampo, 2010).

El Catecismo de Fernández de Sotomayor incitó, sin rodeo y apelando a una retórica democrática, a la promoción de sentimientos que motivaran prácticas de resistencia, rebeldía e insurgencia (tomado al pie de la letra, la ortografía es propia del texto original):

P. Y la conquista no es un motivo de justicia para dominar á la América?

R. La conquista no es otra cosa que el derecho que dá la fuerza contra el débil, como el que tiene un ladrón, que con mano armada y sin otro antecedente que el de quitar lo ajeno, acomete á su legítimo dueño, que, ó no se resiste, ó le opone una resistencia débil. Los conquistados así como el que ha sido robado pueden y deben recobrar sus derechos luego que se ven libres de la fuerza ó pueden oponerle otra superior.

P. Que derechos son estos que pueden recobrar los conquistados?

R. Los mismos que gozaban antes de la conquista: la libertad é independencia del conquistador (Fernández, 1814, pp. 4-5).

Los asuntos de la ciudadanía fueron enseñados a partir de la tensión entre libertad y opresión; ilustración y barbarie. En su desarrollo encontramos el interés por enseñar los prejuicios y estereotipos que tenían los españoles contra «la república de los indios» o habitantes del Nuevo Reino de Granada (tomado al pie de la letra, la ortografía es propia del texto original):

P. Pues qué ¿nosotros somos vasallos de España?

R. No, ni nunca lo hemos sido.

P. Y por que los españoles vindican para sí este derecho?

R. Por que siempre han considerado á los Americanos como hombres de otra especie inferiores á ellos, nacidos para obedecer y ser mandados como si fuésemos un rebaño de bestias (Fernández de Sotomayor, 1820, pp. 6-7). 
El término vasallo o «inferior», tal como se reportó en el texto de Fernández de Sotomayor, no debemos asociarlo con la idea homogénea de una población con los mismos rasgos, características y estatus político-social. Para Traslosheros (2006) la estratificación de la condición de vasallo dependía de dos condiciones: en primer lugar, «la calidad de su sangre». Esto significaba diferenciar entre el nacimiento legítimo (matrimonio) con el ilegítimo (nacido por fuera del matrimonio, en pecado); Adicionalmente y en segundo lugar, los vasallos adquirieron un estatus en razón a su condición de sujeto productivo -esfera económica-.

A pesar de las distinciones en la estratificación, prevaleció la idea de que el vasallo era un sujeto inferior. Para Traslosheros (2006), citando a Juan de Solórzano y Pereyra, el indio vasallo era un hombre miserable del cual había que compadecerse por sus situaciones de humildad y servilismo, pero en especial, por su condición de bárbaro. Los estigmas hacia nuestros antepasados como inferiores, ignorantes, bárbaros, miserables, débiles, oprimidos, entre otros, se asociaban a una falsa idea de condición anatómica. En otras palabras, existió la creencia de que existía una condición innata que hacía que en sus cuerpos estuvieran depositados los sentimientos de enojo, culpa e ira. Estas emociones reactivas explican las razones por las cuales la vida de los vasallos transitó por los amargos infortunios de la irracionalidad y del pecado permanente.

Para contrarrestar su condición de pecadores, como consecuencia de emociones naturales inferiores, se impusieron leyes civiles y reales orientadas a la paz y al público sosiego de quienes no tenían otra condición que ser subordinados y vasallos de monarcas. Como apelativo a la condición precaria de ser vasallo, los españoles, representados por miembros de la iglesia, propusieron fortalecer el sentimiento de compasión. Este sentimiento se asoció con las prácticas de caridad y protección hacia quienes fueron considerados «de la más baja y humilde condición». Estas creencias justificaron, en buena medida, la presencia de los representantes de Dios en la tierra -la iglesia y la Corona española- (Traslosheros, 2006).

Este panorama explica las razones por las cuales Fernández de Sotomayor convoca a la resistencia, no como delito contra la Corona española, al contrario, indica el autor, un ciudadano no puede dejarle a sus hijos y descendientes como herencia la servidumbre y la opresión (tomado al pie de la letra, la ortografía es propia del texto original): 
P. Y si á pesar de carecer de todo motivo de justica lo intenta con la fuerza, qué recurso nos queda?

R. resistirles en cumplimiento de la ley natural que faculta á todo hombre para oponer la fuerza á la fuerza, con el interés de conservar la vida, la libertad y la propiedad individual.

P. Y en resistirles no se comete algún delito?

R. Antes bien no resintiéndoles, porque el hombre no puede dexar á sus hijos y descendientes la servidumbre y opresión por herencia, como acaéceria dexandole subyugar pacíficamente (Fernández de Sotomayor, 1820, p. 7).

Estas reacciones de Fernández de Sotomayor fueron, de alguna manera, respuesta a los escritos producidos por representantes de la Corona española, a partir de los cuales se buscaba ilustrar a los vasallos en la moral cristiana, en particular en asuntos relacionados con la obediencia y sumisión. Paralelamente, es una respuesta a todas aquellas leyes autoritarias y punitivas impuestas como medida para contrarrestar cualquier nuevo intento de alzamiento contra la Corona, como sucedió con la rebelión comunera (1781).

Recordemos que en 1789 Joaquín de Finestrad escribe su texto El vasallo instruido en el Nuevo Reino de Granada y en sus respectivas obligaciones. En su prefacio indica que esta obra busca «instruir perfectamente al vasallo», por el amor que este le debe tener al Rey, a su patria España y a la Iglesia. Es decir, el interés del manuscrito no es «ilustrar» al ciudadano del Nuevo Reino de Granada, sino evitar nuevos alzamientos que pusieran en cuestión la legitimidad del dominio español. Finestrad propone como objetivo pedagógico en este texto, mostrar el domino y señorío natural que tenían los reyes de España sobre los habitantes de América.

Para alcanzar sus objetivos, Finestrad postula el sentimiento de amor como máxima expresión de obediencia y fidelidad a los soberanos de la patria. Este amor no es entre iguales; surge en relaciones asimétricas entre subordinado/gobernante, vasallo/señor. El sentimiento de amor se despoja de sus atributos, es decir, deja de ser un sentimiento recíproco para significar obediencia sin resistencia y sin alteración de jerarquías de poder:

Las hostilidades, disturbios, las guerras y cuantas sediciones fomentan (sic) los hombres, todas las produce la inobediencia y la falta de subordinación en los inferiores a los superiores y en los vasallos al Rey. Si falta este orden, si se desata en divisionar la unidad de este enlace, 
entonces se asolarán los reinos, caerán las provincias, se arruinarán las casas, se sufrirá la opresión, dominará la calamidad, se destruirá la perfección del cuerpo humano y se oscurecerá el esplendor (Finestrad, 1789, pp. 311-312).

Las acciones y sentimientos asociados a la libertad, en condiciones de invasión, se deben controlar por ser estos inferiores y oscurecer el esplendor del poder de Dios, representado en los «iluminados»: los Reyes. Esta narrativa permite ilustrar la tesis propuesta en esta investigación, en la cual se sostiene que la formación ciudadana ha estado relacionada con el dominio de los sentimientos.

Podemos indicar, entonces, que desde este periodo existe un consenso entre intelectuales, académicos, políticos y funcionarios acerca del papel de la formación moral y/o ciudadana en la vida política, sin embargo hay desacuerdos en lo relacionado con sus propósitos, así como en relación con el lugar que ocupan los sentimientos. Para los representantes de la Corona y seguidores de la Nueva Granada, esta educación debería seguir los aprendizajes monacales centrados en el sentimiento de amor cristiano: «enseñarle amor para la obediencia absoluta al rey, a su amo y a las demás autoridades y para pagar sus diezmos, sin lo cual su salvación no sería posible» (Ahern, 1989, p. 10).

Por su parte, para próceres como Santander, la educación de los negros e indígenas era importante porque significaba la entrada a la civilización. Para este prócer y otros ilustrados, la educación moral y ciudadana debería centrarse en el derecho, en particular en los presupuestos de la filosofía moral y política de Bentham (1981), para quien la fuerza de una norma jurídica descansa en la combinación de fuerzas producidas por los sentimientos de dolor y placer:

cuando es en la forma de placer que se aplican, pueden ser llamados motivos atractivos; cuando adoptan la forma de pena: coercitivos. Cuando los motivos de tipo atractivo se tienen como conectados con un acto, se dice que una recompensa se ofrece; cuando se tienen del tipo coercitivo, que un castigo ha sido establecido (p. 133).

En buena parte del siglo xIx, los procesos de formación ciudadana develan la tensión entre: a) buscar la felicidad y eliminar el dolor por la vía del derecho-Bentham-; b) promover los sentimientos de amor y piedad a Dios -Corona española - y de repugnancia y odio frente a conductas dominadas por pasiones y vicios. Veamos estas tensiones: 
Para los seguidores del pensamiento de Bentham, los sentimientos asociados tanto al dolor como al placer son expresión de la voluntad de seres inteligentes y civilizados, quienes reconocen que las sanciones (dolor) y recompensas (felicidad) sociales, morales y políticas, se experimentan en la medida en que se sigan o no las normas. Una de las tesis de Bentham es que «el fin correcto y justo de todo gobierno es la felicidad de la comunidad» (1981, p. 23). De esta tesis se derivan argumentos como el bien es la suma de la felicidad de los individuos que conforman la sociedad; dicha felicidad es el fin propio de la moralidad. Por ello, la ausencia del dolor y la presencia del placer es el telos hacia el cual un legislador debe dirigir su gobierno.

Es importante señalar que la propuesta acerca de la moral y la legislación de Bentham gozó de popularidad hasta el punto que su obra Principios de legislación universal y legislación penal (1981) se convirtió en texto escolar obligatorio en la cátedra de legislación civil y penal. De ello da cuenta el plan general de estudios en su decreto 3 de octubre 1816.

Durante más de 50 años este texto se convirtió en debate público entre próceres, legisladores, académicos, iglesia y los mismos padres de familia. Las polémicas se centraron en varios aspectos, entre ellos que la obra de Bentham no establece vínculo entre ética y religión. Esto se debe a que el filósofo jurista consideraba que la moral no es de Dios, sino consecuencia de las acciones y del gobierno de las instituciones, pues son estas las que procuran felicidad (placer), pero también los males (dolor). En consecuencia, en procesos de formación ciudadana, la experiencia y la legislación -Gobierno- producen tanto felicidad como dolor.

Otra polémica se refirió a la idea generalizada de que existe en el sujeto un carácter natural que lo hace ser sensible hacia la generación de actos benevolentes y justos. Para Bentham son las experiencias las que fortalecen los hábitos hacia el bien común, no un estado innato. De esta tesis, opuesta al sentimiento de simpatía propuesto por Hutcheson y Hume, se derivan dos argumentos que avivan el debate: a) si los sentimientos de simpatía y los relacionados con el placer y el dolor son innatos, es inútil cualquier tipo de enseñanza; b) si existen verdades morales innatas -Dios en el corazón humano- estas deben estar presentes en sabios e ignorantes (Jaramillo, 2012).

Estos debates se reflejaron en normativas y en textos escolares. Es característico de los periodos que van de 1811 hasta inicios de 1900, encontrar una normativa en la cual se indicaba el texto escolar de educación moral atendiendo a sus contenidos y método de enseñanza. Entre estos, tenemos 
los textos de Bentham (1816), los catecismos (1829; 1865; 1910) y las lecciones de moral, virtud y urbanidad (1846; 1859). Todos estos privilegiaron el método del diálogo por ser considerado sencillo y de fácil comprensión para niños y niñas.

Los textos escolares se encontraban estructurados a manera de pregunta y respuesta. En la mayoría de estos diálogos intervenían personajes del ambiente familiar, como los hijos, quienes interrogan al padre acerca de lo que significa la sociedad, las virtudes, la moral, las relaciones entre iguales y entre niños con adultos, entre otros temas. En estos diálogos se incorporan, con el propósito de ilustrar algún tema, cuentos, poemas y, especialmente, apólogos. Estos últimos fueron privilegiados dado que su objetivo era la formación moral. Es de anotar el valor otorgado a este tipo de narración porque facilitaba el conocimiento de los principios éticos, el planteamiento de una moraleja y la identificación de personajes humanos.

A manera de ilustración en Las lecciones de moral y urbanidad para la infancia, que data de 1846, los diálogos se acompañaron de cuentos relacionados con situaciones de la vida cotidiana, de héroes que participaron en las guerras griegas y romanas, así como de enfrentamientos entre piratas y guerras acaecidas en la Nueva Granada. También se hace uso de historias de filósofos, como las de Montesquieu. Con estas estrategias se buscó formar a la niñez no como infantes, sino como «niños-hombres» de bien, virtuosos, sociables, queridos y respetados en cualquier situación de fortuna o precariedad.

Este texto escolar inicia con un poema al niño, cuyo personaje es, justamente, un infante que va a la escuela; espacio educativo asimilado a las nociones de asilo y lugar de trabajo. Incorporado el niño al ambiente escolar, se procede a exponer el significado de la sociedad y, paulatinamente, a explicar los sentimientos asociados a la virtud y la moral. Entre estos, el sentimiento de solidaridad frente a quienes se encuentran en situaciones de indigencia, pobreza u orfandad. Los sentimientos que tienen mayor presencia en procesos formativos se relación con el amor y la repugnancia. El sentimiento de amor se da en relaciones de sometimiento: entre padre/ hijo; adulto/niño; ciudadanos/Dios. Este sentimiento, que es propio de los seres humanos -innatismo-, también se asocia con las relaciones de poder y jerarquía.

Este sentimiento de amor natural y universal, cuando no es objeto de formación, se degrada en vicios. Por ello, la formación moral debe forta- 
lecer el uso de la razón y reprimir pasiones violentas que turben nuestra capacidad de razonamiento para la toma de decisiones: «Cuan peligroso es dejarnos llevar de esos impulsos que nos privan del uso de la razón... pero sus pasiones, que no supo siempre vencer, oscurecieron no pocas veces el esplendor de su gloria» (1846, p. 26).

El estigma de que las emociones son fuente de irracionalidad y orientan los vicios y defectos, llevó a que en contextos de formación se promoviera el control de los mismos. Se indica en este texto escolar, que ante situaciones de violencia como "alguien quiere quitarme la vida o darme golpes», inicialmente se debe intentar defenderse, seguidamente, imputarlo como crimen, y si ninguna de las dos funciona, es necesario controlar la cólera y la ira. En tal sentido el silencio, la paciencia y la tolerancia forjan el carácter humilde y dócil. Por lo tanto, el sentimiento de indignación empleado para expresar actos de injusticia se asocia con falta de humildad.

En cuanto al sentimiento de repugnancia, este se asocia al carácter imperfecto de los seres humanos y a los vicios. Por ello se propone educar al sujeto en la adquisición de hábitos de urbanidad e higiene. El asco es la expresión contraria de los buenos hábitos; la urbanidad es el modo correcto de control de las emociones negativas y el vínculo perfecto con los otros, pues es señal de civilización, es decir, de agrado y complacencia con los demás.

Esta anatomía del asco y la repugnancia se encarna en el cuerpo, en aquel que no goza de aseo, limpieza, buenos modales y decoro en la mesa y en la sociedad:
¿No tembláis cuando veis que os acerca una mano asquerosa?: Tened pues cuidado de no causar a los demás tan repugnancia: reflexionad que una persona asquerosa es un objeto del cual huye uno lo más pronto que pueda. Sed pues cuidadoso en el aseo y limpieza de todo vuestro cuerpo (1846, p. 88).

La anatomía del asco y la repugnancia es objeto de enseñanza en las lecciones denominadas de «la buena crianza y la buena educación». Esta incluye el estudio de la cortesía, la urbanidad y la política. Para alcanzar la anhelada perfección del hombre, y con ello la convivencia y la civilización, se propone formar a los hombres en emociones que no denoten «afeminación» y a las mujeres en los sentimientos que cultiven la prudencia y la moderación. Estas engendran el sentimiento de repugnancia cuando corresponden a las miradas atrevidas de los hombres, mientras que cultivan el 
sentimiento de benevolencia cuando se mantienen en silencio: «el silencio es el adorno mas hermosos de una mujer» (Sófocles, Lecciones de moral y virtud, 1846, p. 121).

Los anteriores objetivos de formación ciudadana se mantienen en el texto Catecismo Republicano de instrucción popular, publicado en 1865. Además de continuar con la formación en urbanidad, se fortalece la condición servil de los ciudadanos de Estados Unidos de Colombia; condición subordinada que los eleva al estatus de seres bien criados. Se mantiene la idea de una anatomía de la repugnancia y el asco, pero se incorporan los sentimientos de dignidad, honor y respeto al poder civil. Estos últimos sentimientos se cultivan porque el objetivo del texto escolar fue destacar y mantener vivo el recuerdo de los próceres e ilustres mártires que contribuyeron a la fundación de la República.

Aunque en este texto se buscó fortalecer los derechos individuales por ser considerados los que más interesan al pueblo y porque explican las razones por las cuales la organización política de nuestros país es la republicana, el interés pedagógico fue «popularizar los principios cardinales de la organización política» en la población infantil. Los niños (masculino) fueron considerados más de la República que de la familia, pues son hijos del pueblo. Correspondía al Rey velar por la formación en la primera infancia. Para ello, se propuso alabar con cantos a los héroes y, con ello, promover los sentimientos de fidelidad y amor. Se excluye de esta formación el azote y el sentimiento de vergüenza pública, es decir, todas aquellas situaciones que señalen al niño como ignorante, incapaz e indigno.

En este texto se combina la didáctica del canto con la estrategia de la pregunta-respuesta. Llama la atención que en la explicación acerca de la conquista se indique que el fin de la educación en la colonia fue mantener ignorante al «bajo pueblo» y prohibir la enseñanza de la política. Esto justifica la alabanza y exaltación a los sacrificios que realizaron nuestros héroes de la independencia. Entre estos se incluye a Policarpa Salavarrieta. En estas alabanzas no se deben fomentar los sentimientos de odio y venganza. Al contrario, se debe promover el sentimiento de humanidad, por ser él máxima expresión que deben tener los ciudadanos. Este sentimiento se expresa en el derecho a la libertad, en especial para el ejercicio de la industria, la movilización, la instrucción y la expresión de pensamientos, entre otros. Por ello, la esclavitud fue considerada un ultraje. La paz pública es la máxima expresión del goce de los derechos. 
Esta temática acerca de los próceres, pero complementada con una historia de Colombia con énfasis en la demografía y geografía, se hace presente en el Catecismo de Historia de Colombia, publicado en 1908. Uno de los estigmas que prevaleció fue la denominación de «salvajes» para referirse a los indígenas, quienes mueren y van despareciendo «destruidos por la miseria en que viven y porque se cruzan con la raza blanca» (1908, p. 5). En el texto escolar se indica que en la Conquista teníamos entre 8 y 10 millones de indígenas, pero en la República de Colombia pasamos a 4 millones y medio más o menos. Esta población disminuyó no solo por la miseria, sino por la guerra y la falta de higiene.

El sentimiento de humillación de los Conquistadores hacia los indígenas prevalece en esta narrativa de la historia de Colombia, así como en los relatos acerca de sus condiciones de pobreza y salvajismo (los indomables). Sentimiento que se eleva a la creación de una capilla llamada el «Humilladero». Estas tribus, a lo largo del texto, son dibujadas como poblaciones bárbaras, antropófagas e incultas; prefirieron su muerte antes que perder su libertad. Esta comprensión de lo humano de los indígenas se asocia con los sentimientos de odio y rabia; sentimientos que los conducen a la muerte. Si lo indígenas morían por los sentimientos de ira y dolor, los esclavos por tristeza.

Los sentimientos de amor, pero en especial de odio e indignación, motivan la narrativa de la sangre derramada en los periodos entre 1600 y 1800. En medio de la sangre, indica el texto escolar, se fundan las primeras escuelas, universidades para instruir a los hijos de los caciques indígenas y conquistadores, así como se fundan un hospital y una biblioteca pública de Santafé con sus librerías.

Hacia finales de 1800, siguiendo el texto, «imperaba el malestar y el desorden en ciudades y campos», sin embargo se reformaron las instituciones educativas (Colegio del Rosario, San Bartolomé, los Colegios de los departamentos, entre otros), se impartió no solo la instrucción intelectual, sino la moral y religiosa, las cuales se habían suprimido durante más de veinticinco años. Finaliza este texto escolar con la aprobación de su publicación por los responsables de la Censura Eclesiástica, por ser considerado una obra digna de alabanza y escrita con criterio católico. 


\subsection{Conflicto armado e impacto en la escuela: ejercicio ciudadano ${ }^{8}$}

Aunque en este proyecto no se indaga a los niños, niñas y jóvenes acerca de la noción de justicia, se buscó conocer la incidencia que tienen los programas de formación cívica y los resultados de las pruebas SABER, en competencias ciudadanas, en los aprendizajes democráticos de niños, niñas y jóvenes ubicados en zonas de conflicto interno colombiano. Para ello se establecieron un conjunto de factores asociados al aprendizaje democrático, los cuales permiten determinar cómo están los niños, niñas y jóvenes en este campo. Estos factores fueron: contexto, conocimientos, actitudes, acciones, emociones y ambientes democráticos. Estos cinco últimos componentes son evaluados en las pruebas SABER en competencias ciudadanas.

\begin{tabular}{|c|c|c|c|}
\hline \multicolumn{4}{|c|}{ Aprendizaje Ciudadano } \\
\hline FACTORES & ÍNDICES & CATEGORÍAS & $\begin{array}{l}\text { CRITERIOS ANALÍtICOS } \\
\text { Análisis de impacto }\end{array}$ \\
\hline \multirow[t]{2}{*}{ CONTEXTO } & $\begin{array}{l}\text { ÍNDICE } \\
\text { SOCIO- } \\
\text { ECONÓMICO }\end{array}$ & $\begin{array}{l}\text { Empleo } \\
\text { Necesidades básicas } \\
\text { insatisfechas } \\
\text { Condiciones de vida } \\
\text { Desarrollo humano }\end{array}$ & \multirow[t]{2}{*}{$\begin{array}{l}\text { Condiciones socio- } \\
\text { económicas y de violencia } \\
\text { de los departamentos entre } \\
\text { el } 2005 \text { y el 2006, en los } \\
\text { que se aplicó la prueba } \\
\text { SABER del } 2005 . \\
\text { Muestra: } 4 \text { departamentos. }\end{array}$} \\
\hline & $\begin{array}{l}\text { ÍNDICE POLÍ- } \\
\text { TICO }\end{array}$ & $\begin{array}{l}\text { Acciones violentas } \\
\text { del conflicto armado } \\
\text { Victimas de desplaza- } \\
\text { miento } \\
\text { Víctimas de masacres } \\
\text { Accidentes con minas } \\
\text { antipersonales }\end{array}$ & \\
\hline
\end{tabular}

8 En este estudio las investigadoras principales fueron Marieta Quintero y Sara Victoria Alvarado. Se contó con el apoyo de la investigadora Jennifer Mateus y, en calidad de estadístico e investigador, con Juan Carlos Miranda. Como joven investigador participó Edwin Giovanny Rubio. Estudio titulado Programas de formación y evaluación de competencias ciudadanas en zonas de conflicto interno colombiano: análisis de impacto en los aprendizajes ciudadanos, financiado por el ICFES y COLCIENCIAS. Este proyecto fue ejecutado por la Universidad Distrital Francisco José de Caldas y CINDE, e identificado con el código 113051828140. 


\begin{tabular}{|c|c|c|c|}
\hline FACTORES & ÍNDICES & Categorías & $\begin{array}{c}\text { Criterios Analíticos-Análisis } \\
\text { de impacto }\end{array}$ \\
\hline \multirow[t]{2}{*}{$\begin{array}{l}\text { FORMACIÓN } \\
\text { CIUDADANA }\end{array}$} & $\begin{array}{l}\text { CURRÍCULO } \\
\text { PARA LA } \\
\text { FORMACIÓN } \\
\text { CIUDADANA }\end{array}$ & $\begin{array}{l}\text { Referentes curricu- } \\
\text { lares } \\
\text { Conocimientos } \\
\text { Acciones } \\
\text { Emociones } \\
\text { Actitudes } \\
\text { Ambientes democrá- } \\
\text { ticos }\end{array}$ & \multirow[t]{2}{*}{$\begin{array}{l}\text { Contraste de lo encon- } \\
\text { trado en la aplicación de } \\
\text { los instrumentos con los } \\
\text { resultados de las pruebas } \\
\text { SABER } 2005 . \\
\text { Muestra: } \\
3 \text { programas de formación, } \\
4 \text { departamentos. }\end{array}$} \\
\hline & $\begin{array}{l}\text { PROGRAMAS } \\
\text { DE FORMA- } \\
\text { CIÓN EN } \\
\text { CIUDADANÍA }\end{array}$ & $\begin{array}{l}\text { Referentes curricu- } \\
\text { lares } \\
\text { Conocimientos } \\
\text { Acciones } \\
\text { Emociones } \\
\text { Actitudes } \\
\text { Ambientes democrá- } \\
\text { ticos }\end{array}$ & \\
\hline \multirow[t]{3}{*}{$\begin{array}{l}\text { AMBIENTES } \\
\text { DEMOCRÁ- } \\
\text { TICOS }\end{array}$} & $\begin{array}{l}\text { ÍNDICE DE } \\
\text { AMBIENTE DE- } \\
\text { MOCRÁTICO } \\
\text { FAMILIAR }\end{array}$ & $\begin{array}{l}\text { Nivel educativo de los } \\
\text { padres } \\
\text { Profesión } \\
\text { Violencia intrafamiliar } \\
\text { Clima familiar }\end{array}$ & \multirow[t]{3}{*}{$\begin{array}{l}\text { Contraste de lo encontra- } \\
\text { do en la aplicación de los } \\
\text { instrumentos con los resul- } \\
\text { tados de las pruebas SABER } \\
2005 . \\
\text { Muestra: } 4 \text { departamentos. }\end{array}$} \\
\hline & $\begin{array}{l}\text { ÍNDICE DE } \\
\text { AMBIENTE DE- } \\
\text { MOCRÁTICO } \\
\text { ESCOLAR }\end{array}$ & $\begin{array}{l}\text { Nivel y tipo de forma- } \\
\text { ción de los docentes } \\
\text { Experiencia de los do- } \\
\text { centes en el área } \\
\text { Ambiente institucional } \\
\text { Clima de aula } \\
\text { Proyectos transversales }\end{array}$ & \\
\hline & $\begin{array}{l}\text { ÍNDICE DE } \\
\text { AMBIENTE DE- } \\
\text { MOCRÁTICO } \\
\text { DE BARRIO O } \\
\text { VEREDA }\end{array}$ & $\begin{array}{l}\text { Ambientes y situa- } \\
\text { ciones del de barrio: } \\
\text { maltrato, abuso, ex- } \\
\text { clusión, resolución de } \\
\text { conflictos, derechos y } \\
\text { cuidado. }\end{array}$ & \\
\hline
\end{tabular}


Para dar cuenta del objetivo general de la investigación, orientado a determinar la incidencia de los programas de formación y la prueba SABER, se procedió, tal como se señaló anteriormente, a analizar los factores asociados a los aprendizajes ciudadanos. A partir de lo encontrado en la prueba SABER en competencias ciudadanas del 2005, se elaboró la revisión de literatura -antecedentes- y de informes de evaluación cívica nacionales, internaciones e índices que recogen factores asociados a las prácticas democráticas de los niños, niñas y jóvenes (Objetivo general).

Con el objeto de analizar estos factores, se adoptó el estudio de caso múltiple. Para ello se seleccionaron 4 departamentos del país: 2 de ellos que obtuvieron puntajes inferiores a la media nacional (Atlántico y Cundinamarca) en la aplicación de la prueba SABER del 2005, y 2 que tuvieron de los mejores desempeños, el cual corresponde a 5.61 (Meta y Bolívar).

Para el caso particular de este estudio se adoptaron las siguientes categorías:

\begin{tabular}{|l|}
\hline Conocimiento ciudadano \\
\hline Acciones democráticas \\
\hline Emociones morales \\
\hline Actitudes cívicas \\
\hline $\begin{array}{l}\text { Ambientes democráticos (clima institucional de } \\
\text { aula, clima familiar, clima de barrio o vereda) }\end{array}$ \\
\hline
\end{tabular}

Es preciso indicar que en las teorías de la ciudadanía o en las tradiciones cívicas, las categorías adoptadas han sido consideradas fundamento y objeto de estudio del ejercicio ciudadano. Así, los conocimientos ciudadanos, en tradición republicana, siguiendo a Nussbaum (1995), se refieren a los saberes requeridos para alcanzar la excelencia, moldear el carácter, evaluar situaciones vividas y construir un proyecto de vida conforme a un ideal de virtud.

Por su parte, las acciones en las tradiciones liberal y republicana, se asocian con la praxis ciudadana y denotan el grado de reconocimiento práctico que tienen los ciudadanos acerca de las normas, leyes y pactos establecidos en la esfera de la vida social, pero también en la jurídica.

En relación con las emociones, las distintas tradiciones cívicas reconocen que estas son los móviles de la acción moral y política. Aunque desde la tradición griega se ha considerado que las emociones deben estar bajo un 
dominio racional, también se identifican en estas tres características esenciales para la vida comunitaria: a) cognitiva; b) comunicativa; c) evaluativa.

En tal sentido, las emociones están relacionadas con los juicios de valor, por lo tanto reflejan no solo la forma de vida que una persona elige vivir, sino los marcos de evaluación y los lazos o vínculos que lo mueven a estar o no con los otros o a ser solidario o no con estos (amor, empatía, indignación, resentimiento, entre otros).

En las tradiciones hermenéuticas de la ciudadanía, como la propuesta por Ricoeur, se indica que las actitudes están relacionadas con las aspiraciones que tienen los sujetos a procurarse una vida buena, de manera que se constituyen en un organizador de los planes de vida personal y colectiva.

Asimilamos la categoría ambientes de aprendizaje con la noción de sociedad civil, la cual ha de entenderse, siguiendo a Cohen y Arato (2000), como los espacios de interacción social compuestos por la esfera de la familia y las esferas de las asociaciones -como movimientos sociales- y las formas de comunicación (2000, p. 8). Indican los autores que la sociedad civil representa una dimensión del mundo sociológico de normas, papeles, prácticas y relaciones en relación con las asociaciones y la vida asociativa. En este estudio hemos tomado tres ambientes Ilamados de aprendizaje porque allí se despliegan las experiencias de los niños y jóvenes; estos definen sus modos de relación y asociación con los otros, y son la familia, la escuela y el barrio o vereda.

En las zonas impactadas por distintos fenómenos del conflicto armado, se aplicaron los instrumentos de recolección de información dirigidos a estudiantes, docentes, padres de familia y programas de formación, a partir de los cuales se analizaron los factores asociados a los aprendizajes ciudadanos de niños, niñas y jóvenes. Estos son:

\begin{tabular}{|c|c|c|}
\hline Departamento & Puntaje & $\begin{array}{c}\text { Posición respecto a } \\
\text { las pruebas SABER }\end{array}$ \\
\hline Meta & 5.74 & Por encima \\
\hline Bolívar & 5.73 & Por encima \\
\hline Atlántico & 5.52 & Por debajo \\
\hline Cundinamarca & 5.50 & Por debajo \\
\hline
\end{tabular}


La selección de las instituciones educativas en estas zonas obedece a los siguientes criterios:

a. Aplicación de la pruebas SABER en competencias ciudadanas.

b. Ubicadas en zonas de conflicto armado.

c. Presencia de programas de formación.

Se analizaron tres programas de formación, los cuales se aplicaron en las zonas seleccionadas para el trabajo de campo. Los programas fueron:

\begin{tabular}{|c|c|c|}
\hline Programa & INSTITUCIÓN & $\begin{array}{l}\text { CORRELACIÓN CON LOS DEPARTA- } \\
\text { MENTOS DEL TRABAJO DE CAMPO }\end{array}$ \\
\hline Vivir los Valores en el Aula & PROMIGAS & Atlántico \\
\hline Habilidades para la vida & FE Y ALEGRÍA & Bolívar \\
\hline $\begin{array}{l}\text { Niños, niñas y jóvenes } \\
\text { constructores de paz }\end{array}$ & CINDE & Cundinamarca y Manizales \\
\hline
\end{tabular}

Las instituciones seleccionadas estaban ubicadas en los departamentos del Meta, Cundinamarca, Atlántico y Bolívar.

\begin{tabular}{|l|l|}
\hline \multicolumn{1}{|c|}{ Defartamento } & \multicolumn{1}{c|}{ Municipio } \\
\hline \multirow{4}{*}{ Meta } & Granada \\
\cline { 2 - 2 } & Vista Hermosa \\
\cline { 2 - 2 } & Fuente de Oro \\
\hline \multirow{2}{*}{ Cundinamarca } & Soacha \\
\hline \multirow{2}{*}{ Atlántico } & Sabanalarga \\
\cline { 2 - 2 } & Soledad \\
\hline \multirow{4}{*}{ Bolívar } & Magangué \\
\cline { 2 - 2 } & Carmen de Bolívar \\
\cline { 2 - 2 } & Cartagena \\
\hline
\end{tabular}

En esta investigación se adoptó como enfoque de indagación el estudio de caso múltiple o colectivo de naturaleza mixta (cualitativo-cuantitativo). En su dimensión cualitativa (comprensiva), este estudio permitió caracterizar los conocimientos, acciones, emociones y actitudes que favorecen programas de formación y propuestas educativas institucionales -currículos-para 
que los niños, niñas y jóvenes ubicados en zonas de conflicto interno, se desenvuelvan en diferentes ambientes democráticos (Objetivos específicos 2 y 3$)$.

En el aspecto cuantitativo (analítico) se definieron las variables e indicadores socio-económicos y políticos asociados a los aprendizajes ciudadanos de niños, niñas y jóvenes (Objetivo específico 1). En este mismo componente se describió cómo se encuentran los estudiantes de todo el país en términos del aprendizaje ciudadano a partir de sus resultados en la prueba SABER en competencias ciudadanas del 2005.

En cuanto al impacto del conflicto armado en la vida con los otros, se analizaron cuatro momentos. Estos son:

1. Colonización y violencia de frontera (1870-1940). Gómez Buendía, que señala los inicios del conflicto, se remonta a finales del siglo XIX con el surgimiento y avance del proceso de colonización, proceso que se desarrolló en dos grandes márgenes geográficos;

2. La violencia: ideología, partidismo y revolución social (1940-1970). Este momento trajo consigo el desplazamiento en zonas periféricas del país como consecuencia de las luchas agrarias entre los grupos, pero también como resultado de las luchas partidistas y sociales.

3. Reinvención de las organizaciones sociales y políticas (1970-1990), en la cual el paramilitarismo es el principal generador de violación de DDHH durante este período, así como el incremento de acciones bélicas analizadas a la luz de tres lógicas: macro (dividendo al país en dos zonas de conflicto, noroccidental y suroriental), meso (referida a la dimensión regional por su importancia geoestratégica) y local (relacionada con los municipios como entidades administrativas más pequeñas y ubicadas, algunas en zonas de periferia) (Vásquez, 2003);

4. Narcotización del conflicto (1990-2000). La consolidación de los carteles y la alianza de estos con guerrilla y paramilitares que dieron origen a grandes plantaciones y mercantilización de la droga y la emergencia de «economías de la ilegalidad», lo cual implicó una agudización del conflicto interno por el aumento a los desplazamientos y masacres en regiones y municipios, así como el aumento en los niveles de corrupción en la sociedad y en las instituciones políticas.

El conflicto armado ha traído diversas consecuencias para la vida de infantes y adolescentes de nuestro país, en especial la precarización de sus espacios de socialización y aprendizaje. Precisamente la incursión de grupos armados, el desplazamiento, el reclutamiento y la tortura, por mencio- 
nar algunos fenómenos asociados a este tipo de violencia, han afectado gravemente los entornos de protección de infantes y adolescentes, entre ellos la familia y la escuela, exponiéndolos a graves peligros que atentan contra su integridad y dignidad como personas.

Al respecto, el informe Escuela y conflicto armado: de bien protegido a espacio protector (2009), señala que la violencia asociada a conflictos armados ejercida contra las escuelas de nuestro país, es responsable de que ceca de un millón de niños, niñas y jóvenes no accedan al sistema educativo formal y que a más de 2.5 millones no se les garantice el derecho a la educación por diversas causas. Estas cifras muestran el impacto que tiene la presencia de grupos armados, los enfrentamientos y el fuego cruzado, el reclutamiento forzado y el desplazamiento de poblaciones, por mencionar algunas situaciones asociadas a este fenómeno bélico, en factores escolares como el acceso de niños, niñas y jóvenes.

Asimismo, en este informe se señala que más allá de los daños que ocasionan los combates en la infraestructura y dotación de las instituciones educativas, es necesario tener presente las consecuencias académicas y psicológicas que traen estos hechos a infantes y adolescentes, así como la imposibilidad de construir lazos y vínculos basados en la confianza y la solidaridad. La repetición constante de hechos atroces en centros educativos, también evidencia la falta de recursos y estrategias estatales para garantizar el cumplimiento de los derechos de niños, niñas y jóvenes, en especial protección y salvaguarda de la vida:

Un entorno escolar protector promueve el desarrollo de independencia y responsabilidad para consigo mismo y con los otros; cuando ello se garantiza, es posible esperar que niños y jóvenes concurran a la construcción de un tipo de interacción en el que, por ejemplo, no son necesarias ciertas formas de relación mediadas por la impulsividad y la fuerza, en tanto conllevan implícitamente el mensaje de no respeto y negación del otro (Fundación Dos Mundos, 2011, p. 62).

En este sentido, la violencia por conflicto armado se ha consolidado en los últimos años como un factor determinante para la comprensión del ejercicio ciudadano de la población, no solo en ambientes como la vereda y la familia, sino en espacios educativos. Las fracturas y daños que han ocasionado los fenómenos asociados al conflicto armado, han marcado profundamente lo que significa vivir juntos en nuestro país, impactando en la forma como se conciben las normas, se valoran y respetan los derechos, se protege la infancia, se establecen y cumplen acuerdos, entre otras acciones. 
Dada la importancia que ha cobrado en los últimos años la violencia, y su impacto en los espacios educativos, este estudio buscó indagar con los docentes acerca de la presencia de estos hechos en las instituciones en la que laboran, así como determinar los agentes educativos más afectados por tales sucesos. En este sentido, se investigó acerca de cuáles son los fenómenos del conflicto armado que más afectan la zona en la que laboran.

Los resultados obtenidos frente a este interrogante fueron:

\begin{tabular}{|l|c|l|}
\hline \multicolumn{1}{|c|}{ Fenómeno } & $\%$ & \multicolumn{1}{c|}{ Detos. MÁs AfeCtados } \\
\hline Desplazamiento forzado & $78 \%$ & $\begin{array}{l}\text { Meta: } 90.9 \% \\
\text { Cundinamarca: } 89.6 \%\end{array}$ \\
\hline Reclutamiento forzado & $15.8 \%$ & $\begin{array}{l}\text { Meta: } 36.3 \% \\
\text { Cundinamarca: } 13.7 \%\end{array}$ \\
\hline Minas antipersonales & $12.2 \%$ & $\begin{array}{l}\text { Bolívar: } 12.5 \% \\
\text { Cundinamarca: } 3.4 \%\end{array}$ \\
\hline Masacres & $11.6 \%$ & $\begin{array}{l}\text { Cundinamarca: } 13.7 \% \\
\text { Meta: } 13.6 \%\end{array}$ \\
\hline Retorno & $3.9 \%$ & $\begin{array}{l}\text { Bolívar: } 12.5 \% \\
\text { Cundinamarca: } 3.4 \%\end{array}$ \\
\hline
\end{tabular}

Tal como se observa en el cuadro de resultados, el desplazamiento forzado es el fenómeno que afecta con mayor rigor a las poblaciones encuestadas. Esta situación conversa con los datos oficiales arrojados por el DANE (2006), quien señaló que durante las últimas décadas se evidenció un incremento alarmante de los casos de desplazamiento: en los últimos cinco años casi nueve millones de colombianos -el $24 \%$ de la población registrada en el censo- se vio obligada a migrar de forma forzada. Adicionalmente, 416.000 ciudadanos colombianos migraron de sus lugares de residencia como estrategia para proteger sus vidas frente a amenazas y hechos de violencia. Finalmente, el reporte del DANE indica que el $40 \%$ de la población desplazada corresponde a menores de 20 años, en particular, niños y niñas entre los 9 y los 12 años. Entre las poblaciones más afectadas por este fenómeno se encuentran Quindío, Risaralda, Bogotá, Huila, Meta, Cundinamarca, Atlántico y Valle del Cauca; dos de estos departamentos hacen parte de la muestra de este estudio. 
Debido a la situación de migración, la mayoría de la población termina viviendo en condiciones de hacinamiento, hecho que ponen en riesgo la integridad física de los individuos. Asimismo, la inestabilidad que ocasiona la migración forzada implica poca sistematicidad en los procesos educativos, en especial la pérdida de años escolares, la inasistencia, la deserción, el bajo rendimiento académico y la falta de seguimiento a las dificultades de aprendizaje que se presentan. Sin embargo, las mayores consecuencias de este fenómeno están asociadas a la pérdida de la confianza en el mundo común, ya que la mayoría de personas en esta condición tienen dificultades para reconocer en otros a personas que ayuden y cooperen en la superación de los hechos atroces que han experimentado.

Asimismo, el desplazamiento forzado trae como consecuencia la emergencia de situaciones y manifestaciones de burla y rechazo debido a la condición social, cultural y económica de las personas que recién llegan. Precisamente, en municipios receptores de población desplazada, algunos estudios refieren un incremento de actitudes y acciones discriminatorias en los ambientes educativos, situación ocasionada por el rechazo de docentes y estudiantes a poblaciones que han migrado debido al conflicto armado en la zona donde residen. Estas situaciones exigen abordar desde los contextos educativos estrategias para prevenir estas conductas, así como para facilitar la re-socialización de estas poblaciones, explorando sus capacidades y oportunidades de desarrollo.

Adicionalmente, se encontró en los resultados de la encuesta a los docentes, que otros hechos que afecta a las zonas en las que se realizó el trabajo de campo son el reclutamiento forzado, la presencia de minas antipersonales y las masacres. Tal como lo indica el informe de la Fundación Dos Mundos (2011), estos hechos de violencia vulneran los derechos fundamentales de la población infantil y adolescente. En el primero de los casos, niños, niñas y jóvenes reclutados se ven obligados a realizar prácticas sexuales y militares denigrantes que atentan contra su dignidad como seres humanos. Por su parte, la presencia de minas antipersonales y masacres pone en riesgo la vida e integridad física y emocional de las víctimas y, en los casos más graves, quedan secuelas, traumas y fracturas que impiden a los miembros de una comunidad establecer vínculos basados en la empatía y la confianza en otros.

También se indagó con los docentes si la institución educativa en la que labora ha sido impactada por el conflicto armado. Frente a este interrogante se encontró que el $55.6 \%$ de los entrevistado respondió negativamente, 
lo que evidencia que cerca de la mitad de las escuelas han tenido experiencias de violencia que han afectado sus procesos académicos, artísticos, culturales y deportivos. Del 49.4\% que manifestó que sus instituciones han estado involucradas en tales situaciones, el $21.5 \%$ indicó que afecta la asistencia de los estudiantes a clases, el $21.1 \%$ que impacta negativamente en el clima escolar, el $9.8 \%$ en las labores pedagógicas de docentes y alumnos, el $3.4 \%$ en la entrega de boletines y el $2.8 \%$ en las actividades desarrolladas por los directivos.

Estos resultados son preocupantes ya que indican que un gran número de espacios educativos están siendo afectados por hechos de violencia, lo cual disminuye la capacidad de estos centros para proteger y resguardar a los niños, niñas y jóvenes en situaciones difíciles y de agresión. Tal como lo señalan los docentes, la presencia del conflicto armado afecta, necesariamente, el clima escolar en el que se desarrollan los procesos académicos, ya que hace posible la incursión de grupos armados que reclutan infantes y adolescentes para la guerra, así como se favorecen hechos delictivos asociados a la economía ilegal del conflicto armado.

Asimismo, siguiendo lo expuesto por docentes, los procesos pedagógicos son los que más afectados se ven con la presencia del conflicto armado en las instituciones educativas. Al respecto, un gran número de encuestados señaló que el impacto de la violencia puede evidenciarse en la inasistencia de los estudiantes a las clases, así como en la dificultad para desarrollar las labores pedagógicas (procesos de enseñanza-aprendizaje). En cuanto a la inasistencia, es importante señalar que la presencia de grupos armados pone en peligro la movilidad de niños, niñas y jóvenes hacia las instituciones educativas, ya que pueden ser reclutados, quedar atrapados en fuego cruzado, así como ser víctimas de algún artefacto explosivo.

En el caso de los procesos académicos, los estudiantes que han sido expuestos a hechos de violencia obtienen un bajo desempeño respecto a sus congéneres, situación que obedece a la falta de sistematicidad y seguimiento en los procesos que desarrollan. Recordemos, tal como se indicó anteriormente, que muchos de los estudiantes se ven enfrentados a casos de desplazamiento y reclutamiento forzado, lo que los mantiene alejados de las escuelas por grandes temporadas, hecho que afecta la continuidad en la construcción de conocimientos y competencias básicas en las áreas, acordes con la edad y niveles académicos cursados. 
Otro interrogante que se planteó a los docentes estuvo relacionado con cuáles de los actores educativos habían sido víctimas de acciones violentas. Frente a esta pregunta se encontró que el $27.1 \%$ de los entrevistados indicó que estudiantes, el $17.4 \%$ docentes, el $15.3 \%$ padres de familia, el $2.8 \%$ administrativos y el $1.9 \%$ directivos-docentes. En este sentido, tenemos que la mayor cantidad de hechos de violencia está dirigida a estudiantes, docentes y padres de familia. Las consecuencias que tienen estos hechos sobre los estudiantes, han sido expuestas extensamente en párrafos anteriores. No obstante, no hemos detallado algunas de las consecuencias que tiene la presencia del conflicto para los docentes.

Al respecto, es necesario señalar que en los últimos años se ha incrementado el caso de docentes asesinados debido a sus convicciones políticas respecto al conflicto armado y la violencia dentro de las aulas. Por ello, muchos de los maestros y maestras se enfrentan constantemente a amenazas, torturas, y en casos extremos, desapariciones forzadas como consecuencia de su interés por proteger a los niños, niñas y jóvenes de las acciones de reclutamiento, abuso y violencia a las que son sometidos en contextos de guerra. Precisamente, muchos docentes de nuestro país han sido asesinados o masacrados protegiendo a los estudiantes ante situaciones de enfrentamientos entre grupos armados, toma de sedes educativas, agresión o reclutamiento.

Siguiendo la línea de lo expuesto, la Fundación Dos Mundos en su informe sobre escuela y violencia señala:

Según la Federación Colombiana de Educadores (FECODE), los derechos de los maestros en Colombia son violados de diferentes formas, entre ellas asalto o irrupción en hogares y escuelas por personal armado, asesinato de profesores frente a sus familias y estudiantes, desapariciones forzadas y secuestros, declaraciones públicas o mensajes que los identifican como objetivos militares, y porque con frecuencia los grupos armados que utilizan las escuelas como lugares de encuentro para la difusión de sus opiniones políticas, les somete a diversas amenazas que muchas veces conllevan el desplazamiento (Fundación Dos Mundos, 2011, p. 19).

Asimismo, los docentes que se ubican en escenarios de violencia se enfrentan constantemente al desafío de adelantar labores pedagógicas con poblaciones que están emocional y psicológicamente vulnerables, lo que exige que implementen acciones pedagógicas y democráticas orientadas a apoyar a estos infantes y adolescentes, ayudándolos a superar los hechos 
vividos. Para este tipo de estudiantes y docentes, el conflicto se ha «naturalizado» en sus vidas, por lo que todas los procesos que desarrollan están atravesados por la violencia:

en ocasiones inventan historias sobre los actores del conflicto, se generan rumores de manera muy fácil, porque es posible que cada una de las personas que habita estos lugares conviva con la incertidumbre de lo que algún día sucedió y que puede volver a suceder (Fundación Dos Mundos, 2011, p. 30).

Finalmente, y en coherencia con lo señalado anteriormente, se interrogó a los docentes acerca del tipo de acciones de violencia de los cuales han sido víctimas los miembros de la comunidad educativa. Los resultados obtenidos a esta pregunta se resumen en la siguiente tabla:

\begin{tabular}{|c|c|}
\hline ACCIÓN VIOLENTA & \% \\
\hline Amenazas & $29.2 \%$ \\
\hline Agresiones & $24 \%$ \\
\hline Intimidación & $15 \%$ \\
\hline Persecución & $6.2 \%$ \\
\hline
\end{tabular}

Los porcentajes presentados muestran que los miembros de la comunidad educativa que han sido víctimas de hechos de violencia, se han visto afectados, en la mayoría de los casos, a amenazas y agresiones. Los actores armados buscan crear ambientes de miedo y zozobra entre la población con el fin de que esta cumpla con las obligaciones que le han impuesto para perpetuar el estado de guerra instalado. Para ello, estos agentes utilizan amenazas y advertencias en las que manifiestan su intención de lastimar o dañar a las personas más cercanas a quienes están incumpliendo con lo pactado o están ofreciendo resistencia. Las amenazas se configuran, entonces, como armas poderosas que obligan a los individuos a realizar acciones criminales y delictivas que atentan contra la estabilidad de las comunidades y la vida de sus miembros.

Cuando las amenazas se vuelven inútiles por la oposición de las víctimas o por la gravedad de las exigencias, entonces los actores armados acuden a la agresión física y al maltrato con el único objetivo de someter a los individuos. Cuando los abusos se llevan a condiciones extremas, se presencian fenómenos como la tortura, el secuestro o el asesinato. En ambas circuns- 
tancias, amenazas y agresiones, los ambientes educativos se constituyen en espacios de miedo, terror y violencia en los que se cumplen las leyes de los fuertes sobre los derechos de la población. Debido a la importancia que adquieren estas situaciones de conflicto armado, se hace necesario trabajar en propuestas pedagógicas que aborden cómo atender poblaciones en esta situación, qué protocolos implementar para disminuir los riesgos y cómo apoyar su restitución y restauración.

Relación de los resultados de la prueba SABER con la caracterización socio-económica y política de los departamentos. Al analizar los resultados obtenidos por los 33 departamentos en la aplicación de las pruebas SABER del 2005, se encontró que el promedio del país fue de 5.61 sobre una escala de 10 puntos posibles, lo que reitera la situación crítica en la que nos encontramos. Recordemos que este puntaje es considerado reprobatorio, dado que la media teórica corresponde a 6.0.

Frente al componente de emociones, en lo relacionado con la empatía, se encontró que tiene un lugar destacado en la tabla de resultados, ya que obtuvo un puntaje de 6.7, superando el promedio nacional $(5,6)$. Esta misma situación ocurrió con la categoría de acciones, cuyo puntaje corresponde al 6.3. Los componentes de actitudes hacia la ciudadanía y ambiente familiar, aunque se encuentran por encima de la media nacional, en general no alcanzan el mínimo establecido (6.0). Entre los componentes que más bajos resultados obtuvieron encontramos ambiente familiar, barrio y colegio, con puntajes de 5,8, 5,6 y 5,2, respectivamente.

Con el fin de establecer la incidencia que tienen las condiciones socioeconómicas y políticas de niños, niñas y jóvenes en sus resultados en pruebas SABER en competencias ciudadanas, se procedió a establecer las correlaciones entre los puntajes obtenidos y el índice propio al contexto.

Así, en relación con las actitudes, los niveles de saturación indicaron que el desarrollo de esta competencia ciudadana está más asociada a variables socioeconómicas que a las de tipo sociopolítico. Por su parte, las acciones democráticas (agresiones, inclusión y exclusión) estuvieron más influenciadas por variables relacionadas con el conflicto sociopolítico (desplazamiento, masacres, secuestros, entre otras) que por el factor socioeconómico. De igual manera, las percepciones de los jóvenes al responder la prueba, asocian la confianza con desarrollarse en un contexto social proclive al ejercicio de la ciudadanía. 
En relación con los ambientes democráticos, el análisis factorial indicó que los espacios familiares y educativos no se ven tan afectados por el factor conflicto interno como por el factor socioeconómico. No sucede lo mismo con los resultados obtenidos en el ambiente barrio, en donde se apreció una saturación del lado del componente conflicto interno, lo cual indica que la presencia de violencia armada afecta negativamente el desarrollo de competencias ciudadanas en espacios comunitarios.

Frente a la competencia emocional, en especial lo relacionado con la empatía, se encontró que no se asocia con las variables relacionadas con el conflicto armado. No obstante, se encontró que los resultados obtenidos en las variables asociadas a las competencias emocionales (empatía y manejo de la rabia) se explican más desde las condiciones socioeconómicas, dentro de las cuales estarían los aspectos educativos y culturales, como valores familiares, y otros.

\section{Análisis de factores asociados al aprendizaje ciudadano en los cuatro} departamentos. Para la adopción de las categorías de análisis estadístico y cualitativo que dieron lugar a la creación de los instrumentos de trabajo de campo en asuntos de formación en Competencias Ciudadanas, se retomaron dos documentos de la política pública en educación: Estándares en Competencias Ciudadanas (2004-2006) y Pruebas SABER (2005). Estos referentes nacionales coinciden en señalar que las Competencias Ciudadanas son: «habilidades (cognitivas, emocionales y comunicativas) y conocimientos necesarios para construir convivencia, participar democráticamente y valorar el pluralismo»(MEN, 2004, p. 6).

Adicionalmente, coinciden en valorar los ambientes de aprendizaje (familia, colegio, barrio o vereda) como los escenarios en los que se despliega la formación ciudadana: «la acción ciudadana se da siempre en un contexto. Los individuos actuamos dentro de estructuras y contextos sociales, y esas estructuras y contextos pueden obstaculizar o favorecer el ejercicio de competencias» (MEN, 2004, p. 10). Tal como se indicó anteriormente, para este estudio se adoptaron las siguientes categorías:

Conocimientos ciudadanos. A partir de los resultados obtenidos en los cuatro departamentos, se encontró que en las instituciones educativas se fortalece, principalmente, el grupo de competencias de convivencia y paz, en especial los temas relacionados con el cuidado de la naturaleza, hacerse respetar y el respeto de los derechos. Conocer los derechos permite identi- 
ficar las formas de amparo y defensa que puedan tener los niños para evitar situaciones de vulneración.

Seguidamente tenemos el grupo de competencias de participación y responsabilidad democrática, donde se trabajan particularmente las funciones del gobierno escolar y los mecanismos de participación estudiantil. No obstante es importante señalar que algunos temas, cuyos puntajes se ubican en el lugar más bajo, corresponden a este grupo de competencias. Nos referimos a funciones de los organismos de control del Estado y de las ramas del poder público e, inclusive y aún más preocupante, el tema fines y responsabilidades del Estado.

Finalmente, tenemos que el grupo de competencias ciudadanas que menos se trabaja es pluralidad, identidad y valoración de las diferencias. Recordemos que la valoración de las diferencias es un tema fundamental en la formación de los estudiantes, ya que permite reconocer las características y particularidades de quienes los rodean, aceptando sus opiniones y las distintas expresiones de su pluralidad.

Actitudes cívicas. Al revisar los resultados de los cuatro departamentos se encontró que los niños, niñas y jóvenes conversan, en gran medida, sobre acciones relacionadas con el cuidado del cuerpo. Al respecto, es preciso señalar que el reconocimiento y valoración del cuerpo significa protección y constitución de nuestra identidad. También plantea el interrogante acerca de ¿quién soy yo?, aspecto constitutivo de la subjetividad personal.

Entre las acciones ciudadanas que no se conversan en los ambientes de aprendizaje (familia y barrio) tenemos situaciones, hechos y asuntos referidos a la violencia. También encontramos que existe poca deliberación acerca de la importancia de tener entornos protectores ante situaciones de maltrato. Finalmente, al indagar a los niños, niñas y jóvenes acerca de las acciones ciudadanas realizadas en el último mes, tenemos que la mayoría de estudiantes de $5^{\circ}$ grado participan en grupos que protegen el medio ambiente, lo que evidencia sensibilidad para forjar prácticas de justicia con los animales no humanos y con la naturaleza.

Al indagar a los estudiantes de $9^{\circ}$ se encontró que sus acciones se orientaron al rechazo ante burlas y situaciones de maltrato hacia sus compañeros. Una posible explicación a este resultado fue el debate y aprobación que se realizó en el Senado -en el periodo en el que se aplicó esta entrevista- al tema de violencia escolar. El resultado de estas discusiones fue la aproba- 
ción de la Ley 1520 del 2013, por la cual se crea el Sistema Nacional de convivencia escolar y formación para el ejercicio de los derechos humanos, la educación para la sexualidad y la prevención y mitigación de la violencia escolar.

Actitudes ciudadanas. Entre los resultados encontrados en actitudes, tenemos que los niños, niñas y jóvenes reconocen que los derechos se respetan sin importar raza, credo o nación. Esta percepción ante situaciones que vulneran los derechos, muestra que la mayoría de estudiantes considera los derechos como un conjunto de prerrogativas inherentes al ser humano y, por ello, no deben otorgarse atendiendo a posición social, edad, sexo o religión.

También se encontró que los niños y niñas de estos departamentos, tienen poca confianza en su capacidad de resolución de conflictos y consideran que solo con la intervención de un adulto pueden solucionarlos. En este sentido, es necesario favorecer dentro las instituciones educativas mecanismos orientados a fortalecer la capacidad deliberativa de los estudiantes, así como el manejo asertivo de diferencias y situaciones de conflicto. Otro de los hallazgos fue el reconocimiento de la discriminación no solo como rechazo racial, sino como una manifestación de intolerancia ante los otros, por lo que implica diferentes criterios: orientación sexual, posición social, ideologías, pero también distintos ambientes, como el ámbito laboral.

Finalmente, los jóvenes entrevistados en este estudio consideraron que la libre expresión es un derecho inalienable, por lo que sus opiniones deben ser tomadas en consideración. Así, estos estudiantes señalan que deliberar, opinar libremente, denunciar e imputar en la esfera de lo público es uno de los modos de defensa a la libertad y justicia, pero también un mecanismo de protección ante cualquier situación de vulneración.

Emociones morales. Los resultados obtenidos en esta categoría indican que en los ambientes en los cuales se despliegan los aprendizajes de los niños, niñas y jóvenes prevalece la preocupación por prácticas de cuidado con los animales como seres sensibles, merecedores de respeto y de acciones encaminadas a una existencia digna. Estas prácticas, al ser promovidas, garantizan que los niños, niñas y jóvenes desarrollen la capacidad de preocuparse y relacionarse con otras especies, lo que da a lugar propender por una ética animal. 
Cuando se indagó acerca de qué emoción les suscitaban las peleas entre los compañeros, se encontró que la mayoría de estudiantes indicó tristeza. Aunque un gran número de niños y niñas manifiestan sentirse tristes por esta situación, los porcentajes en todos los departamentos no superan el $50 \%$, lo que muestra baja sensibilidad frente a este tipo de situaciones. Estos resultados pueden indicar que los jóvenes han naturalizado la agresión entre pares, particularmente en ambientes educativos.

Al indagar a docentes acerca de las emociones que se favorecen dentro de la formación ciudadana, encontramos que la amistad es el sentimiento con mayor puntaje, mientras que los sentimientos que obtuvieron de menor a mayor porcentaje fueron: manejo de miedo ante situaciones de rechazo, indignación ante la vulneración de derechos, asertividad en el manejo de situaciones conflictivas, expresión de desagrado ante situaciones de exclusión y discriminación y comprensión de situaciones de tristeza.

Ambientes democráticos. Al indagar a los estudiantes de quinto grado acerca de cómo se solucionan los problemas en la casa, se encontró que la mayoría lo hace conversando. Estos resultados muestran la importancia que adquiere para padres de familia, niños, niñas y adolescentes, resolver los conflictos y situaciones difíciles atendiendo a formas dialogadas y pacíficas, lo que exige reconocer, valorar y tener en cuenta las ideas, opiniones y argumentos de todos los involucrados, de forma que se establezcan acuerdos para su solución.

Asimismo, los resultados obtenidos en las entrevistas a padres y estudiantes también mostraron poca presencia de acciones violentas y de maltrato infantil dentro de los hogares en los que se desarrollan los niños, niñas y adolescentes. No obstante, se encontró que en algunos casos se utilizan los gritos para resolver las diferencias e inconvenientes que se presentan con los miembros de la familia.

También se solicitó a los estudiantes indicar la frecuencia con la que se presentan situaciones de conflicto dentro de la escuela. La mayoría indicó que nunca se presentan este tipo de hechos dentro de las instituciones educativas, y cuando existen situaciones que exigen solución, atienden a lo expuesto en el Manual de Convivencia o utilizan el diálogo como forma de mediación.

Otro aspecto que se preguntó respecto al clima escolar, fue la presencia de situaciones de maltrato entre pares, a lo que se indicó que nunca se 
presentan estos hechos. Esto evidencia un bajo número de peleas, riñas y maltratos o agresiones físicas entre niños, niñas y jóvenes, lo que propicia ambientes educativos armoniosos y favorables para el aprendizaje.

Tanto estudiantes como padres de familia coinciden en señalar que, en la mayoría de los casos, los vecinos se reúnen para resolver pacíficamente las diferencias y conflictos que tienen lugar en la comunidad. Los hallazgos obtenidos en este acápite muestran que en ambientes como el barrio y la vereda, los miembros del grupo social se preocupan por establecer relaciones y vínculos cordiales y de apoyo, orientados a conciliar y concertar las mejores salidas a las dificultades. 


\section{A MANERA DE EPÍLOGO}

En este libro se buscó mostrar la importancia de las justificaciones públicas en asuntos relacionados con la vida moral y política. Para dar cuenta de estos temas se procedió, inicialmente, a la fundamentación de las nociones de justificación y de los sentimientos morales y políticos; nociones asociados a la justicia y a la praxis ciudadana. Los marcos epistemológicos se centraron en Habermas y Rawls, quienes ven en la deliberación pública - lenguaje- una vía para la comprensión de los procesos de construcción democrática, analizando para ello las concepciones y prácticas ciudadanas relacionadas con asuntos de la justicia y con las normas morales y políticas. En otras palabras, asuntos relacionados con la vida, con los otros.

La búsqueda del entendimiento por la vía de la justificación y deliberación pública llevan a mostrar las razones por las cuales tanto Habermas como Rawls adoptaron la noción de justificación pública o lenguaje moral y político. Tendríamos que aclarar que para el desarrollo del tema de la deliberación pública, se mantuvo un diálogo con la teoría de Kant, pero también con los pensadores Piaget y Kohlberg. Recordemos que estos teóricos adoptaron la idea de Kant, en la cual se concibe a los ciudadanos como personas racionales y, por ello, con capacidad de elección y de ejercicio de sus facultades morales para llevar a cabo una vida digna.

Además de considerar que el agente moral está guiado por la razón práctica o por los principios de deliberación racional (lenguaje), la justicia y los asuntos de la práctica ciudadana son el criterio de la moralidad y la política que mejor exhiben los modos de razonamiento de los ciudadanos. Así, las justificaciones públicas nos muestran las reglas y normas reconocidas y aceptadas por los ciudadanos. También nos permite conocer las razones por las cuales no siempre hay acuerdos para participar en la cooperación 
social y en la búsqueda de la equidad o para mantener una comunicación libre de compulsiones o asimetrías.

Este lenguaje moral y político nos muestra las reivindicaciones, resistencias y reclamaciones que tienen los ciudadanos acerca de la vida con los otros. Estos ciudadanos esperan que los valores proclamados en la democracia estén presentes tanto en las instituciones políticas como en las políticas sociales. En consecuencia, en toda justificación pública de la justicia y del ejercicio ciudadano, los ciudadanos muestran el derecho que tienen para realizar exigencias a sus instituciones, promover formas de asociación políticas y no políticas, poseer una concepción del bien, perfilar una forma de vida y participar de la cooperación social. La orientación deliberativa permite mostrar que, en sociedades democráticas, las justificaciones públicas de las concepciones de la justicia y del ejercicio ciudadano no deben estar afectadas por las diversas doctrinas religiosas, filosóficas y morales presentes en la sociedad civil, pues se trata de orientar y guiar la praxis ciudadana a partir de principios que hagan posible la dignidad y el buen vivir.

En el proceso de argumentación conceptual se le otorgó un lugar ponderando a la pragmática moral de los actos de habla. Su importancia radica en mostrar las relaciones estrechas que existen entre lo que decimos o justificamos acerca de lo que hacemos (acciones y lenguaje); justificaciones de los ciudadanos acerca de las normas morales y políticas en relación con sus modos de acción social y comunicativa; justificaciones de los sujetos morales y políticos acerca de sus intenciones, formas y mecanismos de interacción.

Si bien los actos de habla son el carácter revelador del lugar que tiene el lenguaje en la vida moral, las pretensiones de validez expuestas por Habermas y asociadas a estos actos de habla permiten mostrar las razones por las cuales en sociedades plurales y con la presencia de conflictos sociales, los individuos deben buscar el entendimiento apelando a los mecanismos que ofrecen los modos de resolución pacífica (lenguaje moral y político).

Los anteriores marcos de orientación provenientes de la filosofía ética y política permitieron orientar algunas indagaciones prácticas acerca de lo que significa la justicia y el ejercicio ciudadano para niños, niñas y jóvenes colombianos. Para ello se procedió a presentar los resultados de cuatro investigaciones relacionadas con experiencias ciudadanas, dos de ellas centradas en indagar acerca de la justicia, y las otras dos en conocer la praxis ciudadana en la escuela y en escenarios afectados por el conflicto armado. 
En nuestro país, a partir de la década de los noventa, los temas de la violencia, el conflicto armado y la inseguridad se convirtieron en fuente de estudio de investigadores y académicos. Como consecuencia, aumenta la producción, socialización y comunicación de este fenómeno paradigmático del mal en libros, artículos, congresos y cátedras. Sin embargo, la emergencia de este campo de estudio quizá se vea mejor reflejada en los usos estéticos, tradicionalmente no empleados en la academia, y a los que hoy se recurre para narrar el daño moral ocasionado a la población civil y para develar las contingencias y precariedades sufridas en nuestra vida en comunidad. Las películas, videos, cortometrajes e iconografías son, en buena medida, narrativas morales y políticas que contienen los juicios colectivos adoptados por distintas generaciones de colombianos, lo que denota, de un lado compromiso, y del otro, novedad e innovación en su tratamiento.

Esta emergencia o florecimiento de la investigación en la violencia, el conflicto armado, cultura política, formación en valores, ciudadanía y democracia, no significa que en nuestro país, en las constituciones y en los procesos de formación se desconozca la importancia de los derechos de los ciudadanos. Desde la Constitución del Estado de Cundinamarca (1811) se proclaman los derechos a la libertad, seguridad y propiedad, y se demanda por una forma de gobierno apropiada para alcanzar la «felicidad pública». Se exigía a los ciudadanos el uso de sus facultades para reunirse en sociedad con sus semejantes y para reconocer, respetar y poner en marcha los pactos y acuerdos para garantizar el goce de los derechos (Constitución de Cundinamarca, 1811).

Los anteriores ideales coinciden con los presupuestos del contractualismo político de Rawls expuestos en este libro. En la Constitución de 1811 y en el liberalismo político, el ciudadano es entendido como sujeto político con capacidad para justificar los asuntos relacionados con su voluntad de asociación y con la facultad de deliberar acerca de las normas y las leyes reconocidas y aceptadas por todos los ciudadanos. En estas justificaciones políticas no solo encontramos los razonamientos de los ciudadanos y los gobernantes, también se evidencian las normas morales y jurídicas que buscan mediante criterios constitucionales garantizar un sistema democrático.

En cuanto a la noción de «felicidad pública», expresada en la Constitución de 1811, podemos indicar, tal como lo propone Aristóteles, que la felicidad solo se logra dentro de la misma polis, en nuestro caso, dentro de la sociedad democrática. Esta vida buena exige esfuerzo de sus ciudadanos para fomentar las virtudes que lo habiliten para despeñarse en procura de 
sociedades cada vez más humanas. Se trata de reconocer que los ciudadanos justifican el sistema de justicia, sin tener que renunciar a la búsqueda de una vida plena, es decir, a una «buena vida humana». Se trataría, como lo señala Nussbaum, de que "la vida buena ha de poderse alcanzar con el esfuerzo de toda persona no "incapacitada" éticamente, y con quienes coinciden en exigir una vida "propia y difícil de arrebatar", "estable y no sujeta al cambio"» (Nussbaum, 2003, p. 408).

A partir de lo expuesto, podemos señalar que en este libro se buscó, mediante el análisis de las justificaciones acerca de la justicia y las relacionadas con la vida en comunidad, ofrecer vías para entender en los procesos de construcción democrática, la manera como los ciudadanos actúan en las esferas íntima y pública guiados por concepciones, experiencias y prácticas individuales y colectivas en asuntos relacionados con la justicia, la protección, la seguridad y el cumplimiento de derechos.

Tal como se señala en la presentación de este texto, en un país como el nuestro, con una larga historia de violencia, interesa comprender las razones por las cuales, durante los cincuenta años que llevamos de conflicto armado en Colombia, la justicia ha sido concebida por la mayoría de los ciudadanos, incluyendo los jóvenes, como un aparato formal; situación que ha impedido que los ciudadanos colombianos entendamos la justicia y la praxis ciudadana como categorías políticas (Garay, 2002; Gómez Buendía, 2003). Por lo tanto, las evidencias empíricas de los estudios que se presentaron permitieron reconocer la importancia que tiene entender las cuestiones de la justicia y de la praxis ciudadana como un asunto que requiere de la deliberación de todos los ciudadanos y no solo como un problema adscrito a las políticas de la justicia formal. 
Agra M., J. (1985). J. Rawls: El sentido de la justicia en una sociedad democrática. Santiago de Compostela: Universidad de Santiago de Compostela.

Aguirre, A. (1995). Etnografía: Metodología en la investigación sociocultural. Barcelona: Editorial Boixareau Universitaria.

Ahern, E. (1989). El desarrollo de la Educación en Colombia 1820-1850. Universidad Pedagógica Nacional. Texto traducido por Guillermo Arévalo y Gonzalo Cataño.

Amesbury, R. (2003). Agreeing to disagree: Moral argumentation, social Criticism, philosophical contemplation. Tesis Doctoral: The Claremont Graduate University.

Apel, K. O. (2004). ¿Es adecuada, para la justicia global la concepción política del "consenso sobrepuesto"?. En: Senent, J. (Comp.). Filosofía de la convivencia, caminos de diálogo Norte-sur. Madrid: MAD.

Apel, K. O. (1999). Una Ética del discurso o dialógica. Revista Anthropos. Huellas del conocimiento. Barcelona, Monográfico Apel, 183, (marzo-abril), pp. 12-19.

Arendt, H. (1987). Los orígenes del totalitarismo. Tomos I, II, III. Madrid: Alianza.

Austin, J. (1990). Cómo hacer cosas con palabras: palabras y acciones. Barcelona: Paidos. Trabajo original publicado en 1955.

Ayer, A. J. (1965). El positivismo lógico. México: Fondo de Cultura Económica.

Barreto, L. (1993). Lenguaje de la modernidad. Caracas: Monte Ávila.

Bentham, J. (1981). Los Principios de legislación universal y legislación penal. Ramón de Salas (trad.), 5 vols. Madrid: Editora Nacional. 
Benhabib, S. (1991). El otro generalizado y el otro concreto. En: S. Benhabib \& D. Cornella (Eds.). Teoría feminista y teoría crítica, pp. 119-149. Valencia: Ediciones Alfonso el Magnánimo.

Benjamín, W. (1978). Para una crítica de la violencia. México: Premiá Editora.

Benveniste, E. (1976). Problemas de lingüística general. Madrid: Siglo XXI.

Bolívar, A. (2002). ¿De novis ipsis silemus?: Epistemología de la investigación biográfico-narrativa en educación. En: Revista Electrónica de Investigación científica 4(1), Universidad de Granada.

Camps, V. (1976). Pragmática del lenguaje y filosofía analítica. Barcelona: Ediciones Península.

Cárcova, C. M. (2003). Justicia como equidad o sociedad como conflicto. Lectura crítica del liberalismo político. Colección derecho, economía y sociedad. Buenos Aires: Facultad de Derecho, Universidad de Buenos Aires.

Carnap, R. (1965). Conocimiento y verdad. En: A. Ayer (Comp.). Positivismo lógico, pp. 171-204. México: Fondo de Cultura Económica. (Trabajo original publicado en 1932).

Carreño, M. (1927/1997). Compendio de Urbanidad y Buenas Maneras. Bogotá: Panamericana.

Carvajal, J. (2000.) Lo razonable y el consenso entrecruzado. Revista Ciencias Humanas, 24, pp. 15-22. Universidad Tecnológica de Pereira.

Craemer-Ruegenberg, I. (1976). Lenguaje, moral y moralidad. Buenos Aires: Alfa.

Colombia (1991). Constitución Política de Colombia. Bogotá: Legis.

Colombia (1811). Constitución del Estado de Cundinamarca. Bogotá: Colección constituciones de la Biblioteca Luis Ángel Arango. Disponible en: http://www. banrepcultural.org/blaavirtual/derecho/constitucion-de-cundinamarca-su-capital-santafe-de-bogota-1811.

Cohen, J. \& Arato, A. (2000). Sociedad civil y teoría política. México: Fondo de Cultura Económica.

DANE (2006). Censo General 2005. Cuadros básicos censales. Total Nacional, Departamental y Municipal: Población total censada en hogares particulares y lugares especiales de alojamiento, por sexo, según departamentos, áreas y grupos de edad. Disponible en: http://www.dane.gov.co/ 
Defensoría del Pueblo y MEN (2007). Plan Nacional de Educación en Derechos Humanos.

Derrida, J. (2001). Justicia y perdón. Madrid: Trotta.

Derrida, J. (2003). El siglo y el perdón seguido de fe y saber. Buenos Aires: De la Flor.

De Lora, P. (2004). Annette Baier y Michael Walzer Acerca de la ética normativa y el filósofo moral. En: Doxa, (2)15-16. Alicante.

Echavarría, C.; Quintero, M. \& Vasco, E. (2005). Algunas concepciones de la justicia de un grupo de estudiantes universitarios de dos ciudades del país. Revista Científica 7, pp. 315-332. Bogotá: Universidad Distrital.

Escandell, M. (1996). Introducción a la pragmática. Barcelona: Editorial Ariel.

Fairfield, P. (1999). Deliberative Democracy. The review of politics (61), pp. 61-91. Notre Dame: Summer.

Fernández, J. (1820). Catecismo o instrucción popular. Santafé: Imprenta del CBE.

Finestrat (1789). El vasallo instruido en el estado el Nuevo Reino de Granada y sus respectivas obligaciones. Disponible en: http://www.bdigital.unal.edu. co/1333/2/01PREL01.pdf

Fuentes, J. (2003). Paradigmas de la filosofía política contemporánea. En: Pensamiento Cuba Siglo XXI, No. XXXII. Agosto 2003. La Habana. Disponible en: http://www.nodo50.org/cubasigloXXI/pensamiento2.htm

Fundación Dos Mundos (2009). Escuela y Conflicto Armado: De bien protegido a espacio protector. Disponible en: http://www.observatoriodelainfancia.es/oia/ esp/descargar.aspx?id=2502\&tipo=documento.

Garay, J. (2002). Repensar a Colombia: Hacia un nuevo contrato social. Bogotá: Agencia Colombiana de Cooperación Internacional-PNUD.

Giusti, M. (2001) Ética; política y sociedad. Caracas: OEl. Cátedra de Educación en Valores, septiembre de 2001. Disponible en: http://www.campus-oei.org/ valores/giusti.htm

Gilligan, C. (1985). La moral y la teoría: Psicología del desarrollo femenino. México: Fondo de Cultura Económica (Trabajo original publicado en 1982).

Gómez B., H. (2003). El conflicto, callejón sin salida. Colombia: Informe Nacional de Desarrollo Humano para Colombia. 
Guerra M., J. (2011). Ética y género: la cuestión de los sentimientos morales. Material inédito.

Habermas, J. (1984). Teoría de la acción comunicativa: complementos y estudios previos. Madrid: Cátedra.

Habermas, J. (1987). Teoría de la acción comunicativa, Tomo I. Madrid: Taurus.

Habermas, J. (1994). Conciencia moral y acción comunicativa. Barcelona: Península.

Habermas, J. (1998). «Razonable» versus «verdadero», o la moral de las concepciones de mundo. En: Debate sobre el liberalismo político, pp. 147-181. Barcelona: Paidós.

Habermas, J. (2000). Aclaraciones a la ética del discurso. Madrid: Trotta.

Habermas, J. (2002). Verdad y justificación. Madrid: Trotta.

Habermas, J. (2004). Fundamentalismo y terror. Diálogo con Jurgüen Habermas. En: G. Borradori. La filosofía en una época del terror, pp. 53-77. Buenos Aires: Santillana Ediciones Generales..

Hare, R. (1999). Ordenando la ética. Barcelona: Ariel.

Heller, Á. \& Feher, F. (1998). Políticas de la postmodernidad: ensayos de crítica cultural. Barcelona: Península.

Heller, Á. (2004). Teoría de los sentimientos. Barcelona: Coyoacán.

Heller, Á. (1989). Las normas del gusto y otros ensayos. Barcelona: Península.

Hoyos, G. (1995). Ética comunicativa y educación para la democracia. Revista Iberoamericana de Educación, 7, enero-abril, pp. 65-91. Barcelona.

Hoyos, G. (1998a). El ethos de la Universidad. En: UIS-Humanidades, (27)1, enero-junio, pp. 13-23. Bucaramanga.

Hoyos, G. (1998b). "Educación y ética para ciudadanos". Las transformaciones educativas. Tres desafíos: democracia, desarrollo e integración. Buenos Aires: OEI/FLACSO Troquel.

Hoyos, G. (2000). Formación ética, valores y democracia. En: Estado del arte de la investigación en educación y pedagogía en Colombia. Bogotá: ICFES, COLCIENCIAS y Sociedad Colombiana de Pedagogía-SOCOLPE. 
Hoyos, G. \& Martínez, M. (2004). ¿Qué significa educar en valores hoy? España: Octaedro, OEl.

Honneth, A. (1997).La lucha por el reconocimiento. Barcelona: Crítica.

Honneth, A. (2009). Crítica del agravio moral, patologías de la sociedad contemporánea. Argentina: Fondo de Cultura Económico.

Honneth, A. (2010). Reconocimiento y menosprecio sobre la fundamentación normativa de una teoría social. Buenos Aires: Katz.

Honneth, A. (2011). La sociedad del desprecio. Madrid: Trotta.

Hudson, W. (1987). La filosofía moral contemporánea. Madrid: Alianza.

Hume, D. (1990). Disertación sobre las pasiones y otros ensayos morales. Barcelona: Anthropos.

Hume, D. (1992). Tratado sobre la naturaleza humana. Madrid: Tecnos.

Hume, D. (2003) Investigación sobre la moral. Buenos Aires: Losada.

Hume, D. (2006). Investigación sobre los principios de la moral. Madrid: Alianza.

Hutchenson, F. (1999). Escritos sobre la idea de virtud y sentido moral. Madrid: Centro de estudios políticos y constitucionales.

Jaramillo, R.; Bermúdez, A. \& Escobedo, H. (2001). Prueba de comprensión, sensibilidad y convivencia ciudadana. Informe de resultados, Calendario B. Bogotá: Secretaria de Educación Distrital.

Jaramillo, D. (2012). Bentham y los utilitaristas colombianos del siglo XIX. Idas y Valores (4) 13, p. 14.

Kant, I. (1973). Fundamentación de la metafísica de las costumbres. Manuel García Morente (Trad.). Madrid: Espasa-Calpe (Trabajo original publicado en 1785).

Kant, I. (1989). La metafísica de las costumbres. Adela Cortina Orts y Jesús Conill Sancho (Trad.). Madrid: Tecnos (Obra original publicada en 1797).

Kohlberg, L. (1978). Moral Development. New York: Longman.

Kohlberg, L. (1987). El enfoque cognitivo evolutivo de la educación moral. Barcelona: Promociones y Publicaciones Universitarias. 
Kohlberg, L. (1992). Psicología del desarrollo moral. Bilbao: Biblioteca de Psicología Desclée de Brouwer.

Laden, A. (2003). The house that jack built: thirty years of reading Rawls. Review, Ethics, (2)113, pp. 367-390. The University of Chicago.

Levinas, E. (1991). Ética e infinito. Madrid: Visor.

Lind, G. (2008). La moral puede enseñarse. México: Trillas.

Lind, G. (1998). Lineamientos curriculares de educación ética y valores humanos. Bogotá: MEN.

MacCarthy, T. (1995) La Teoría crítica de Jürgen Habermas. Madrid: Tecnos.

Maclntyre, A. (1987). Tras la Virtud. Barcelona: Crítica.

Ministerio de Educación Nacional (2009). Plan Nacional de Educación en Derechos Humanos (PLANEDH)..

Mejía, O. (1994). Concepción política de la justicia y liberalismo procedimental: El giro de John Rawls. Revista del Rosario, 564, junio, pp. 54-76. Bogotá.

Moon, D. (2003) Rawls and Habermas on public reason: Human Rights and global Justice. En: Annual Reviews, (6)1, march, pp. 257-274.

Moore, G. (1997). Principia Ethica. México: Universidad Nacional Autónoma de México, Instituto de Investigaciones Filosóficas (Trabajo original publicado en 1903).

Mouffe, Ch. (1999). Deliberative democracy or agonistic pluralism? Social Research, (66)3, pp. 745-758. New York.

Navarro, P. \& Díaz, C. (1994). Análisis de contenido en métodos y técnicas cualitativas de investigación en ciencias sociales. Madrid: Editorial Síntesis, S. A.

Neurath, O. (1965). Sociología en Fiscalismo. En: A. Ayer Positivismo lógico, pp. 287-321. México: Fondo de Cultura Económica (Trabajo original publicado en 1932).

Nino, C. (1989). Constructivismo epistemológico: Entre Rawls y Habermas. Madrid: Centro de Estudios Constitucionales.

Nubiola, J. L. \& Conesa, F. (1999). Filosofía del lenguaje. Barcelona: Herder. 
Nussbaum, M. (1995). La fragilidad del bien. Fortuna y ética en la tragedia y la filosofía griega. Madrid: Visor.

Nussbaum, M. (1997). Justicia poética, la imaginación literaria y la vida pública. Barcelona: Andrés Bello.

Nussbaum, M. (2003). La terapia del deseo: Teoría y práctica en la ética helenística. Barcelona: Paidós.

Nussbaum, M. (2006). El ocultamiento de los humano: repugnancia, vergüenza y ley. Buenos Aires: Katz.

Nussbaum, M. (2008). Paisajes del pensamiento. Barcelona: Paidós.

Ocampo, J. (2010). El cura Juan Fernández de Sotomayor y Picón. Bogotá: Universidad del Rosario.

Patiño, A. (1998). El lenguaje moral y jurídico en John Austin. En: A. L. Gómez (Comp.). Argumentación: Actos lingüísticos y lógica jurídica, pp. 89-106. Cali: Universidad del Valle. Pieper, A. (1991). Ética y moral. Una introducción a la filosofía práctica. Barcelona: Crítica.

Piaget, J. (1977). El criterio moral en el niño. Barcelona: Editorial Fontanela (Trabajo original publicado en 1932).

Prichard, H. (1960). Moral obligation and duty and interest. Oxford: Oxford University Press.

Pinzón, C. (1865). Catecismo Republicano: Instrucción popular. Bogotá: Mosaico.

Provincia de Bogotá (1846). Educación de la infancia: Lecciones de virtud moral y urbanidad. Bogotá: Lozada.

Quintero, M. \& Restrepo, B. (1999). Autonomía y racionalidad comunicativa. Revista Pedagogía y Saberes 13, pp. 65-71. UPN. Quintero, M., Restrepo, B. \& Sánchez, W. (2002). Itinerarios de los discursos en la reconstrucción de la lógica moral en el joven universitario. Proyecto de investigación financiado por Colciencias. En prensa.

Quintero, M. (2006). Justificaciones de jóvenes universitarios y jóvenes desplazados acerca de la concepción de justicia. Manizales: Centro de Estudios Avanzados en Niñez y Juventud, alianza de la Universidad de Manizales y el CINDE.

Rawls, J. (1996). Sobre las Libertades. Barcelona. Madrid: Paidos, ICE- UAB. 
Rawls, J. (1997). Teoría de la Justicia. México: Fondo de Cultura Económica.

Rawls, J. (1998). Réplica a Habermas. En: Debate sobre el liberalismo político, pp. 75-142. Barcelona: Paidós.

Rawls, J. (2001). Derecho de gentes y una revisión de la idea de razón pública. Barcelona: Paidós Ibérica.

Rawls, J. (2002). La justicia como equidad: Una reformulación. Barcelona. Paidós Ibérica.

Retuerto, A. (2002). Desarrollo del pensamiento prosocial y empatía en la adolescencia. Valencia: Servie de Publicaciones.

República de Colombia. Ministerio de Educación Nacional-MEN (1998). Lineamientos Curriculares en Constitución Política y Democrática. Bogotá: MENMagisterio.

Restrepo, B. \& Quintero, M. (2000). Lógica del desarrollo moral de jóvenes universitarios. Investigación financiada por Colciencias.

Restrepo, B. \& Quintero, M. (1999). Historia y narratividad. Barcelona: Paidós.

Rest, J. (1979). Development in judging moral issues. Minneapolis: University of Minessota Press.

Reyes, M. (1991). La razón de los vencidos. Barcelona: Anthropos.

Reyes, M. (1997). Memoria de occidente. Actualidad de pensadores judíos olvidados. Barcelona: Anthropos.

Reyes, M. (2003). En torno a una justicia anamnética. En: J. Mardones \& R. Mate (Comp.). La ética ante las víctimas, pp. 100-125. Barcelona: Anthropos.

Ricoeur, P. (1996). Tiempo y narración. Vol. 3. El tiempo narrado. México: Siglo XXI (Trabajo original publicado en 1985).

Ross, S. (1939). The right and the good. Oxford: Oxford University Press.

Ruiz, A. \& Cháux, E. (2004). Formación de competencias ciudadanas. Bogotá: ASCOFADE, MEN.

Ruiz, A. \& Cháux, E. (2004). Estándares Básicos de Competencias Ciudadanas. Bogotá: MEN-Magisterio.

Ruiz, A. \& Cháux, E. (2004). Portafolio de programas e iniciativas en competencias ciudadanas. Bogotá: MEN-Magisterio. 
Senado de la República (1997). Ley 387, del 24 julio de 1997. En: Diario Oficial No. 43.091. de 24 de julio de 1997. Bogotá.

Schlick, M. (1965). Positivismo y Realismo. En: A. J. Ayer. Positivismo lógico, pp. 88-114. México: Fondo de Cultura Económica (Trabajo original publicado en 1932).

Sobrevilla, D. (1987). El programa de fundamentación de una ética discursiva de Jürgen Habermas. Ideas y Valores 74-75, agosto-diciembre, pp. 99-117. Bogotá.

Smith, A. (1997). La teoría de los sentimientos morales. Madrid: Alianza. Stevenson, C. (1971). Ética y lenguaje. Buenos Aires: Paidós (Trabajo original publicado en 1944).

Strawson, P. (1995). Libertad y Resentimiento. Barcelona: Paidós.

Thiebaut, C. (1997). Sujeto liberal y comunidad: Rawls y la unión social. En: Enrahonar quaderns de filosofia, 27, pp. 19-33.

Thiebaut, C. (2000). Juzgar la acción, rechazar el daño e imputar responsabilidad. Sobre la supuesta crisis de la razón moral. En: Taula. Quadems de pensament, 33-34, pp. 15-28.

Traslosheros, J. (2006). Orden judicial y herencia medieval en la nueva España. Herencia Mexicana, (55)4, abril-junio, pp. 1105-1138. México: El Colegio de México.

Tungendhat, E. (1990). El papel de la identidad en la constitución de la moralidad. Ideas y Valores, 83-84, diciembre, pp. 3-14. Bogotá: Universidad Nacional de Colombia.

Tungendhat, E. (2002). Problemas. Barcelona: Gedisa.

Vasco, E.; Echavarría, C. \& Botero, P. (2004). Temas y situaciones de conflicto moral desde el punto de vista de un grupo de jóvenes colombianos. Revista Alternativas, Serie Espacio Pedagógico, Año 9, 35-36, pp. 191-204.

Vasco, E.; Echavarría, C. V. \& Quintero, M. (En prensa). Ética, moral y ciudadanía: una trayectoria grupal por las teorías, las controversias y las perspectivas de investigación. Revista Alternativas, Serie Espacio Pedagógico.

Wallace, M. (2001). Unfair to Justice. The political science reviewer. Wilmington Fall.

Walzer, M. (1993). Las esferas de la justicia: una defensa del pluralismo y la igualdad. México: Fondo de Cultura Económica. 


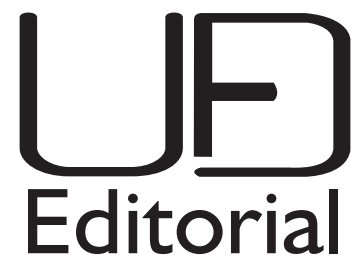

Este libro fue compuesto en caracteres

Optima y Trebuchet MS.

Impreso en 2014

en los talleres de Javegraf.

Bogotá, Colombia.

Quintero Mejía, Marieta

Justificaciones públicas : el lenguaje en la vida moral y política / Quintero Mejía, Marieta. -- Bogotá : Universidad Distrital Francisco José de Caldas, 2014.

122 páginas; $24 \mathrm{~cm}$.

ISBN 978-958-8832-89-0 / ISBN digital 978-958-8832-90-6

1. Lenguaje y lenguas - Aspectos sociales 2. Comunicación -

Aspectos sociales 3. Lenguaje - Vida pública 4. Filosofía del lenguaje I. Tít.

$401.4 \mathrm{~cd} 21 \mathrm{ed}$.

A1457352

CEP-Banco de la República-Biblioteca Luis Ángel Arango 


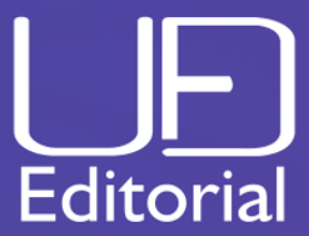

Desde la antigüedad griega se considera que el lenguaje, por su estructura intersubjetiva, configura el Ethos o conjunto de rasgos y comportamientos de un sujeto o una comunidad. Por ello, en buena medida, los filósofos de la moral y la política, desde distintos marcos y métodos de análisis, se han orientado al estudio del significado del lenguaje para indagar asuntos relacionados con las acciones morales y políticas, así como para analizar los compromisos, acuerdos, promesas y juicios de valor que emiten los ciudadanos en sus vínculos comunitarios y en sus relaciones con las instituciones políticas.

En este libro se analizan, precisamente, corrientes y tendencias centradas en el estudio de las justificaciones en asuntos relacionados con la justicia, pero también con la injusticia. Asimismo se presentan investigaciones en las cuales el tema central es indagar acerca de la vida con los otros, en especial, en el marco del conflicto armado. 